\title{
Volume 4, Number 2
}

\section{Hipatia Press}

www.hipatiapress.com

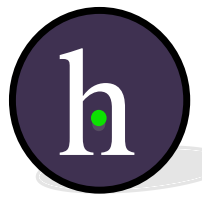

Equipo Editorial Revista BRAC

Editorial -

Visual Jaume Muxart, pintor de cap a peus

Pages Jaume Muxart

Articles La Nueva Condición Transitiva de la Imagen

Josu Larrañaga Altuna -

La Experiencia de la Metáfora como Alternativa a la Invalidez Digital

Alejandro Sanjurjo Rubio -

El holograma como Experiencia Artística

Angel Alonso -

Dibujo Fisionómico del Rostro. Historia de una Deriva entre la Clasificación y la Ficción

Andrea Lucio Sotelo -

Reviews Tecnología y Creación Musical

Salvador Oriola Requena - 
Instructions for authors, subscriptions and further details:

http://brac.hipatiapress.com

\section{Editorial}

Equipo editorial Revista BRAC ${ }^{1}$

1) Universitat de Barcelona, España

Date of publication: June $3^{\text {rd }}, 2016$

To cite this article: (2016). Editorial. Barcelona, Research, Art, Creation, 4(2), 115-3. doi: 10.17583/brac.2016.2107

To link this article: http://dx.doi.org/10.17583/brac.2016.2107

\section{PLEASE SCROLL DOWN FOR ARTICLE}

The terms and conditions of use, except where otherwise noted, are related to the Open Journal System and to Creative Commons Attribution License (CCBY). The indication must be expressly stated when necessary. 
BRAC - Barcelona Research Art Creation. Vol. 4 No. 2, June 2016, pp. $115-117$

\section{Editorial}

Equip Editorial BRAC. (2016)

Universitat de Barcelona

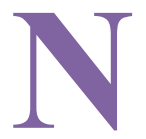

\section{AU CÔCLEA. 20 ANYS}

La Revista BRAC manifesta el reconeixement al Centre de Creació Contemporània Nau Côclea i a la seva directora Clara Garí Aguilera per l'aportació a l'art contemporani durant 20 anys d'activitats artístiques continuades i innovadores.

La Nau Cóclea ubicada a Camallera (Alt Empordà- Catalunya) ha esdevingut un centre referencial de l'art contemporani espanyol .

Les activitats organitzades per la Nau Côclea (exposicions, festivals, publicacions periòdiques, catàlegs, llibres, televisió, concerts, encontres literaris, residencies d'artistes internacionals, rutes, formació, conferencies, producció de projectes artístics, beques, etc...) han qüestionat les maneres habituals de percebre i difondre l'art i han cercat noves vies per integrar la creació amb el territori i els seus habitants.

Des del seu inici, l'any 1996, la Nau Côclea ha fet ben evident que són molts els llocs de l'art i moltes les maneres de produir-lo i difondre'l. L'esperit generós dels seus fundadors, la lucidesa de Clara Garí i l'actitud col·laboradora de tants i tants participants han consolidat un projecte al qual desitgem llarga i renovada vida.

Àlex Nogué

Editor Principal 
BRAC - Barcelona Research Art Creation. Vol. 4 No. 2, June 2016, pp. $115-117$

\section{Editorial}

Equipo Editorial BRAC. (2016)

Universitat de Barcelona

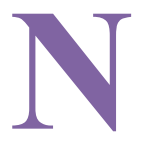

\section{AU CÔCLEA. 20 AÑOS.}

La revista BRAC manifiesta el reconocimiento al Centro de Creación Contemporánea Nau Côclea y a su directora Clara Garí Aguilera por la aportación al arte contemporáneo durante 20 años de actividades artísticas continuadas e innovadoras.

La Nau Côclea, ubicada en Camallera (Alt Empordà- Catalunya) ha se ha convertido en un centro de referencia del arte contemporáneo español.

Las actividades organizadas por la Nau Côclea ( exposiciones, festivales, publicaciones periódicas, catálogos, libros, televisión, conciertos, encuentros literarios, residencias de artistas internacionales rutas, conferencias formación, producción de proyectos artísticos, becas, etc...) han cuestionado las maneras habituales de percibir y difundir el arte y han buscado nuevas vías para integrar la creación con el territorio y sus habitantes.

Desde su origen en el año 1996, la Nau Côclea ha puesto en evidencia que son muchos los lugares del arte y muchas las maneras de producirlo y difundirlo. El espíritu generoso de sus fundadores, la lucidez de Clara Garí y la actitud colaboradora de tantos y tantos participantes han consolidado un proyecto al que le deseamos larga y renovada vida.

\section{Àlex Nogué \\ Editor Principal}


BRAC - Barcelona Research Art Creation. Vol. 4 No. 2, June 2016, pp. $115-117$

\section{Editorial}

BRAC Editorial Team. (2016)

University of Barcelona

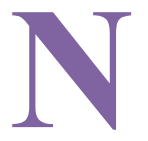

\section{AU CÔCLEA. 20 Years}

The BRAC Magazine expresses its appreciation to the Center of Contemporary Creation Nau Côclea and to its Director Clara Garí Aguilera for her contribution to the contemporary art during a periode of 20 years of innovative and constant artistic activities.

The Nau Côclea, located in Camallera (Alt Empordà-Catalunya) has become a referencial center for the Spanish contemporary art.

The activities organized by the Nau Côclea (exhibitions, festivals, periodical publications, catalogues, books, television documents, concerts, literary meetings, residences for international artists, cultural routes, educational trainings, conferences, production of artistic projects, scholarships, etc...), have questioned the ordinary methods of perceiving and spreading art and have researched new ways to integrate creation into the territory and its inhabitants.

From its very beginning in 1996, the Nau Côclea has revealed that there are many places for the art and many ways to produce and diffuse it. The generous spirit of its founders, the Clara Gari's lucidity and the cooperative attitude of all the participants have consolidated a project to which we wish a long and renewed life.

Àlex Nogué

Main Editor

2016 Hipatia Press

ISSN: 2015-8992

DOI: 10.17583/brac.2016.2107

Hipatia Press

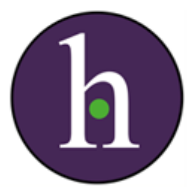


Instructions for authors, subscriptions and further details:

http://brac.hipatiapress.com

Jaume Muxart, pintor de cap a peus

Jaume Muxart ${ }^{1}$

1) Pintor

Date of publication: June $3^{\text {rd }}, 2016$

Edition period: June 2016 - October 2016

To cite this article: Muxart, J. (2016). Jaume Muxart, pintor de cap a peus. Barcelona, Research, Art, Creation, 4(2), 118-120. doi: 10.17583/ brac.2016.2106

To link this article: http://dx.doi.org/10.17583/brac.2016.2106

\section{PLEASE SCROLL DOWN FOR ARTICLE}

The terms and conditions of use, except where otherwise noted, are related to the Open Journal System and to Creative Commons Attribution License (CC-BY-NC-ND). The indication must be expressly stated when necessary. 


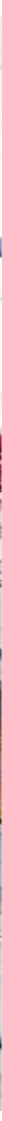




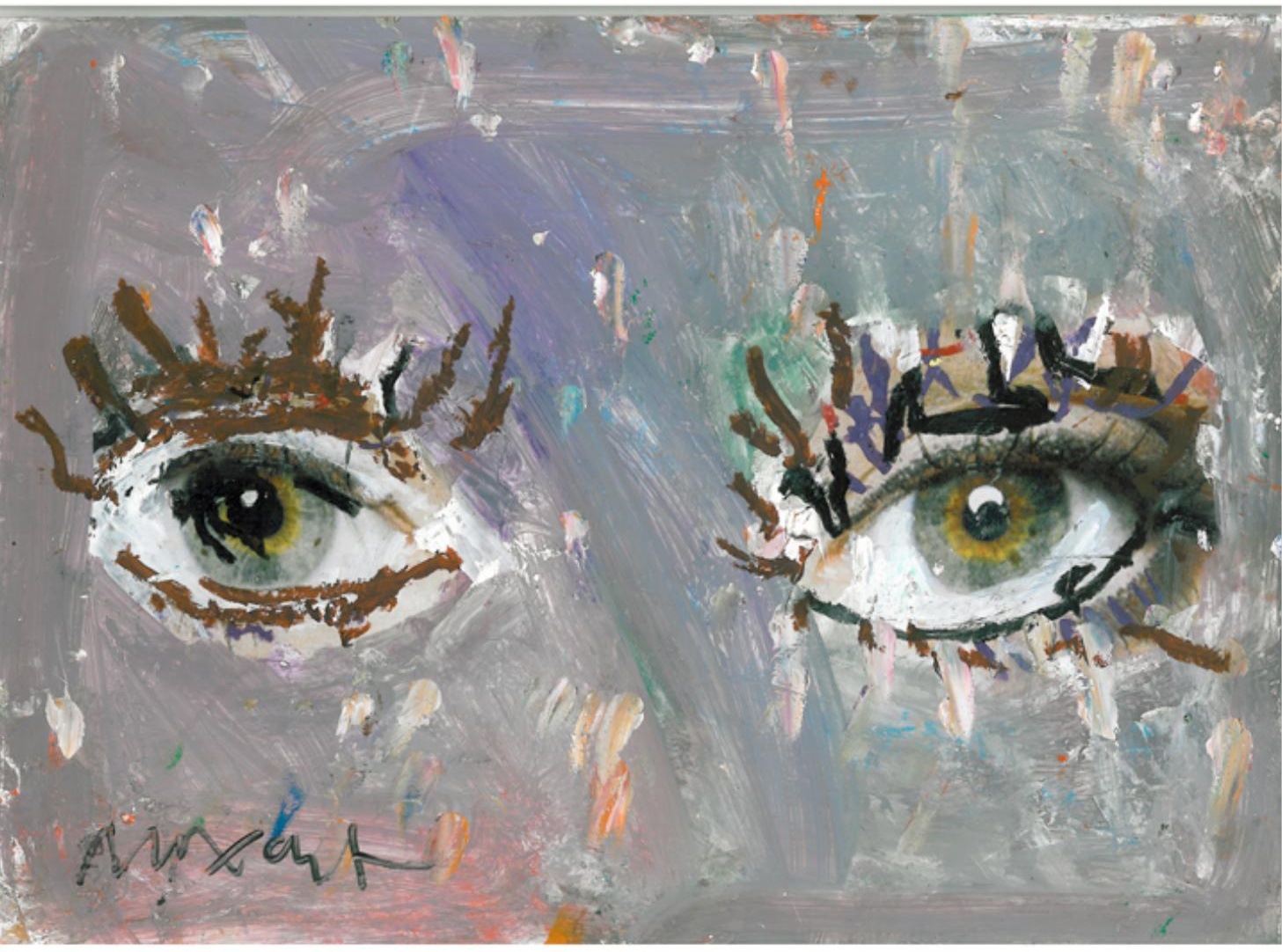



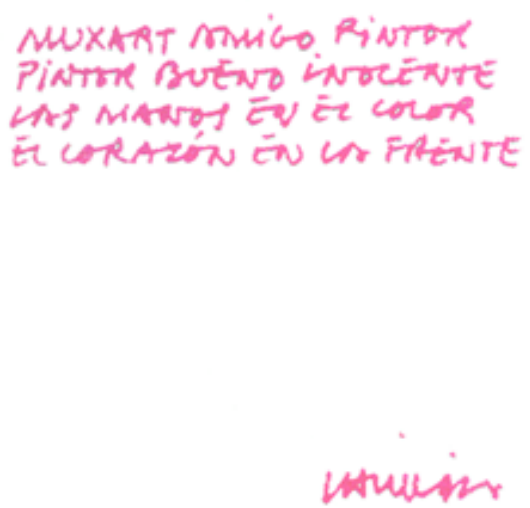

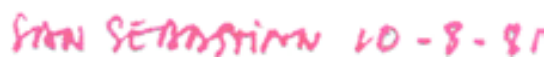

A Jaume Muxart,

El petit poema que l'Eduardo Chillida et dedicà pel catàleg de la teva exposició a "Dau al Set" de l'octubre de 1981, condensa a la perfecció el que tots nosaltres subscrivim coneixent-te com a pintor, professor i company a la facultat de Belles Arts. Entre les teves qualitats personals destaca la gran generositat de la qual, l'obra que ens has donat per les Pàgines Visuals de la revista BRAC, n'és un clar exemple."M'agradaria morir pintant" afirmes, contundent, a manera de manifest personal i això és altra mostra de la teva autenticitat; gràcies Jaume. 
Instructions for authors, subscriptions and further details:

http://brac.hipatiapress.com

\section{La Nueva Condición Transitiva de la Imagen}

Josu Larrañaga Altuna ${ }^{1}$

1) Universidad Complutense, Madrid (España)

Date of publication: June $3^{\text {rd }}, 2016$

Edition period: June 2016 - October 2016

To cite this article: Larrañaga, J. (2016). La nueva condición transitiva de la imagen. Barcelona, Research, Art, Creation, 4(2), 121-136. doi: 10.17583/ brac.2016.1813

To link this article: http://dx.doi.org/10.17583/brac.2016.1813

\section{PLEASE SCROLL DOWN FOR ARTICLE}

The terms and conditions of use, except where otherwise noted, are related to the Open Journal System and to Creative Commons Attribution License (CCBY). The indication must be expressly stated when necessary. 
BRAC - Barcelona Research Art Creation. Vol. 4 No. 2, June 2016, pp. 121-136

\section{New Condition Transitive of the Image}

Josu Larrañaga Altuna

Complutense University, Madrid (España)

(Received: 12 November 2015; Accepted: 7 April 2016; Published: 3 June 2016)

\section{Abstract}

The combination of new devices for converting images applied to art- especially multispectral pictures, 3D-printers and scanners- and revaluation of contextual, performative and communicative aspects in the perceptual process- to the detriment of the object or the environ- underline the fragile and slipperiness of visual synthesis, and in turn, make the transitive emerging potential of every image.

Keywords: Art, image, perception, transimage 
BRAC - Barcelona Research Art Creation. Vol. 4 No. 2, June 2016, pp. 121-136

\section{La Nueva Condición Transitiva de la Imagen}

Josu Larrañaga Altuna

Universidad Complutense, Madrid (España)

(Recibido: 12 Noviembre 2015; Aceptado: 7 Abril 2016; Publicado: 3 Junio 2016)

\section{Resumen}

La combinación de los nuevos dispositivos de conversión de imágenes aplicados al arte- en especial las fotos multiespectrales, las impresoras y escáneres 3D- y la revalorización de los aspectos contextuales, performativos y comunicativos en el proceso perceptivo- en detrimento del objeto o el medio- subrayan el carácter frágil y deslizante de las síntesis visuales, mostrando a su vez la potencialidad transitiva de toda imagen

Palabras clave: Arte, imagen, percepción, transimagen 


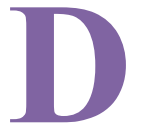

urante el otoño de 2006, la Fondazione Giorgio Cini, con el acuerdo del Museo del Louvre, encargó a la empresa FactumArte la realización de un facsímil de Las bodas de Caná, de Paolo Caliari, conocido como El Veronese. Un año después, el público que llenaba el refectorio del monasterio de San Giorgio Maggiore de Venecia podía contemplar un duplicado de la pintura, realizado mediante la combinación de fotos multiespectrales, escaneado e impresión tridimensional ${ }^{1}$.

Se trata de una transcripción de 9,55 x 6,98 metros, que reproduce fielmente aquella que los benedictinos encargaron al maestro veneciano en 1562 , y que fue requisada en 1797 por los franceses, tras la campaña de Italia, y posteriormente adquirida mediante permuta en 1815, que hoy se encuentra en París. Mientras esta, el facsímil, ocupa la pared del monasterio en la que Veronese y sus ayudantes la colgaron.

El extraordinario desarrollo de los dispositivos de conversión digito/ material, basados principalmente en la combinación de fotografía de precisión, escáneres e impresoras tridimensionales, ha permitido en los últimos tiempos la realización de facsímiles de todo tipo de obras de arte, entre ellos, un buen número de pinturas. Pero la realización e instalación de la copia de Veronese supone un gran salto cualitativo, porque por un lado nos acerca extraordinariamente a la posibilidad técnica de duplicar cualquier imagen, y por otro, nos permite comparar las condiciones perceptivas de ambas obras en relación a las previsiones de quienes pensaron, encargaron, realizaron y ubicaron la obra de arte, y por lo tanto, a la manera en que el espectador la percibe como tal.

El original se encuentra en el museo del Louvre desde 1798. Para ser trasladado desde Italia, hubo de ser desmontado, fragmentado, y posteriormente reconstruido. Desde entonces ha sido restaurado en diversas ocasiones, la última de ellas entre 1990 y $1992^{2}$. En ella participaron historiadores, comisarios, restauradores e investigadores del LRMF que radiografiaron la obra y realizaron diversos análisis estratigráficos, llevándoles a tomar distintas decisiones, algunas de las cuales supusieron la eliminación de capas de pintura $\mathrm{u}$ otras modificaciones cromáticas, en relación a lo que podían ser añadidos y restauraciones anteriores ${ }^{3}$. 
El cuadro se encuentra actualmente en la Salle des Etats frente a la Gioconda, y rodeada de pintura veneciana del siglo XVI. Considerada "la más grande y la más prestigiosa" del Museo de Louvre, la sala fue rehabilitada entre 2001 y 2005. Sus paredes están acabadas en estuco de color siena. La obra enmarcada con una moldura dorada está colgada de la pared a $70 \mathrm{~cm}$. del suelo y hasta unos cuatro metros del techo. A ambos lados se abren grandes huecos de acceso que conectan con ventanales de las paredes adyacentes. A los asistentes al museo se les encamina, por medio de carteles con una reproducción de la Gioconda y un texto que anuncia "pintura italiana", y acceden a la sala a través de estas aberturas, dando la espalda al enorme cuadro de Veronesse. La aglomeración arrastra al visitante hacia la obra de Leonardo, entre una nube de móviles y cámaras y entre cuadros de distintas dimensiones, montados en una o dos filas, que cubren los laterales de la sala. Con bastante esfuerzo, el espectador podrá darse la vuelta y volver por un costado, a contracorriente, para poder contemplar el gran cuadro de las bodas de Caná. Entonces comprobará que la escasa luz blanquecina que cae desde el techo acristalado de la sala, apenas permite identificar los colores y las formas construidos sobre el lienzo.

Nada que ver con aquella pintura pensada para adaptarse al fondo del refectorio de San Giorgio Maggiore, encajada entre la cenefa superior (que es la base del arco de la nave), y el oscuro zócalo que eleva el cuadro más de dos metros, hasta situarlo por encima del punto de vista de cualquier espectador. Nada que ver con aquella pintura (hoy esta transcripción) abrazadas y en diálogo con la arquitectura de Palladio. La conexión entre el banquete de bodas pintado y el comedor usado por los monjes, se concretaba visual y experiencialmente en el vínculo de la perspectiva con las paredes, los huecos de ventana, el techo, las mesas y los asientos donde reposaban y se alimentaban. La altura a la que se cuelga tiene que ver con esta continuidad. Y naturalmente, a la estancia se accede de frente y por el centro, y desde la habitación anterior ya puede verse al fondo la enorme pintura, enmarcada y atrapada por una habitación iluminada por amplios ventanales laterales, que la rodean de luz, y por el marco de piedra de la puerta de acceso.

Hay una enorme distancia entre pasear por las salas de un museo reformado en el XXI y recorrer un monasterio benedictino, pero en este caso además, hay unos itinerarios de acceso, una volumetría, unas condiciones espaciales, unos elementos de intermediación, una conformación cromática de las paredes y paramentos, y un tratamiento de la luz, completamente diferentes. Y hay además un contexto histórico e institucional distinto. 
$\mathrm{Si}$ "en la modernidad el museo se convirtió en un refugio para imágenes que habían perdido su lugar en el mundo, y que lo canjearon por un lugar del arte" (Belting, 2007, p.77), lo que se pone de manifiesto también, con esta nueva imagen/facsímil, es la revisión de la idea de arte en la sobremodernidad, un arte (ahora) que se aleja de la fetichización del objeto y la seguridad de su medio, para subrayar la experiencia perceptiva y las condiciones en las que puede producirse una agitación intelectiva, emotiva y sensible, en los cuerpos, en las personas, es decir, las condiciones en las que se produce aquello que llamamos recepción. Porque como dice Didi-Huberman, "las imágenes se abren y se cierran como nuestros cuerpos que la miran, es decir que las imágenes son creadas por nosotros a nuestra imagen: no solo a la imagen de nuestro aspecto, sino de nuestros actos, de nuestras crisis, de nuestros propios gestos de apertura" (Didi-Huberman, 2013, p.30).

Desde el punto de vista de la recepción, de las condiciones experienciales en las que se da a ver la misma estampa, de su instalación, estamos ante dos imágenes. Especialmente si, como afirma S. Jaschko, el espacio artístico se ha vuelto performativo, "un espacio en donde la actividad viva, el experimento procesual y el diálogo entre la obra, los artistas y sus audiencias constituyen la obra de arte. El objeto físico o el sistema continúan desempeñando un papel, pero sin que se los pueda aislar del resto de componentes del proceso" (Jaschko, 2010).

Estas dos condiciones de experiencia se manifiestan especialmente en la luz, o más certeramente, en la manera en que esta cae sobre el lienzo, es decir, la condición de la forma de lo visible, porque de acuerdo con M. Foucault (leído por G. Deleuze), "en pintura lo primero es la luz. Primero por relación a las líneas, primero por relación a los colores. Los colores y los trazos derivan de la luz, y no a la inversa. Un cuadro es ante todo un trazado de luz" (Deleuze, 2013, pp. 200 y 99). Nada que ver entre una y otra fuente de luz, pero sobre todo, nada que ver entre la manera en que en un caso se difunde y en el otro se precipita entre las formas coloreadas del lienzo.

Y lo mismo sucede con el conjunto de accesorios y ornamentos que compiten y agitan el cuerpo de la imagen en cada una de sus escenificaciones. Ese parergon a-significante y a-representativo, esos elementos que "están fuera de obra, «coadyuvantes» que no están ni afuera ni adentro" (Derrida, 2001 , pp.49 y sig.). Por ejemplo, ese marco, que es moldura en el museo y sin embargo era arquitectura en el lugar de procedencia donde la imagen se contempla mientras se contradice. El propio título (Las bodas de Caná), 
que ha sido recuperado ahora en el refectorio, en el lugar donde comían los monjes, y en consecuencia ha sido rescatado ahora para la percepción, por efecto de su reubicación en San Giorgio Maggiore.

Encontramos también diferencias fundamentales, desde el punto de vista de la recepción para los espectadores, en la disposición de sus cuerpos, en la experiencia espacio/temporal en la que pueden entrelazarse enunciados y visualidades ("cuerpo vivo, donde este debe ser entendido como cuerpo medial o «medializado»: Belting, 2007). Con el uso social de cada uno de los lugares, es decir con la actitud y el trabajo del que percibe en uno y otro caso, de sus expectativas, de sus recorridos, de los archivos de imágenes que cada una de las tentativas reclama del espectador. Y en la construcción simbólica que se ha apropiado de cada una de las instalaciones, porque ahora que tenemos un facsímil instalado en el refectorio, la obra de Veronese en el Louvre remite inmediatamente a las causas de ese desgarramiento, al hurto de Napoleón y a las intrigas del barón de Denon para no restituir la pintura a Venecia.

Nos encontramos entonces ante un cuerpo de la imagen (facsímil), cuya diferencia con el original es por un lado mínima y por otro imperceptible para el espectador. O si queremos, cuyos datos y estímulos visuales son prácticamente iguales. Y que además se encuentra en el lugar originario y en las condiciones de recepción más cercanas a las que fueron previstas por el autor. Aunque, por otro lado, como ejercicio cultural, habrá que apuntar que el consenso y la autoridad de ambas estampas, no es el mismo.

Como se ve, la irrupción de esta nueva imagen/facsímil nos plantea demasiados asuntos que no podrían ser tratados adecuadamente en un sencillo trabajo como este. De manera que deberemos centrar nuestra atención en uno de ellos: lo haremos en el de la nueva condición transitiva de la imagen, que esta historia de reproducciones, resignificaciones y emplazamientos, pone en primer término. Quizás el vertebral, porque muestra una nueva ecología de la mirada y una reconsideración de las condiciones perceptivas que producen una nueva imagen y, en consecuencia, una nueva condición de la experiencia. 

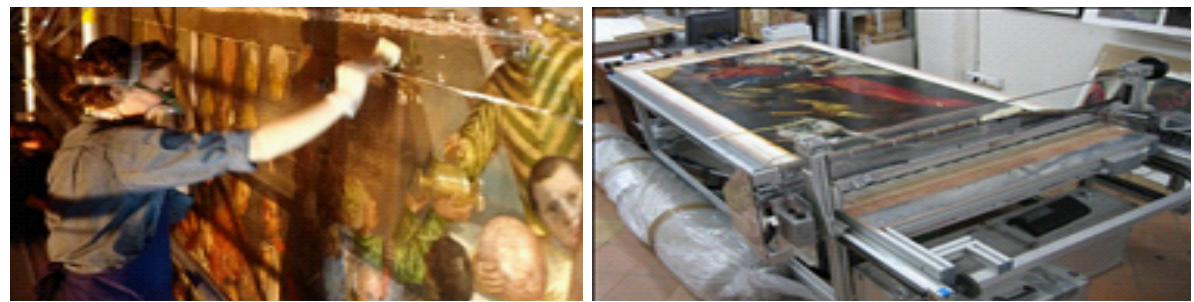

Figuras 1, 2. Izquierda: Proceso de restauración de la obra de Las bodas de Caná de Veronese, 1990-92 (fuente: Servicio de restauración de los museos de Francia). Derecha, Impresión 3D sobre lienzo preparado, de un fragmento del facsímil de Las bodas de Caná, 2006 (fuente: Factum Arte).
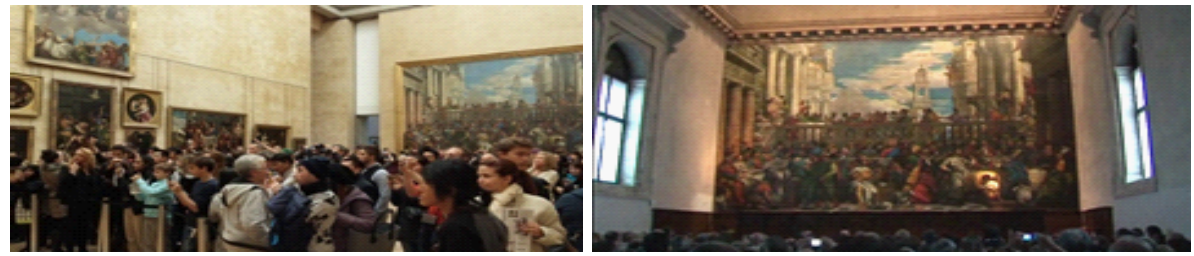

Figuras 3, 4. A la izquierda, la obra de Veronese instalada en la Salle des Etats del Museo del Louvre. A la derecha facsímil instalado en el refectorio de San Giorgio Maggiore de Venecia, el día de su presentación.

\section{Otras Imágenes}

Las imágenes actúan de una u otra manera en relación a las necesidades para las que se les reclama. Poseen esa capacidad proteica de modificar su aspecto adecuándolo a las expectativas propias de su recepción. Proteicas, por un lado, porque las imágenes están construidas mediante la combinación de cualidades paradójicas (conjuntos de aspectos materiales y virtuales, sensibles e intelectivos, visuales y táctiles, expresivos y comunicativos...) que les permiten actuar de forma diversa en contextos y escenarios múltiples, es decir, porque descansan en la condición multiforme y conversacional del proceso de elaboración de una síntesis perceptiva; por otro, porque las imágenes hacen 
suyo el flujo contingente de promesas, aportaciones, posibilidades y fantasías técnicas, enunciativas, interpretativas o tecnológicas que se producen cultural e históricamente, integrándolas en su condición imaginaria. Es así que el carácter proteico de la imagen se alimenta en una circulación de prótesis sucesivas que la atraviesan en el tiempo (Metz, 2001; Jay, 2004; Brea, 2005).

Lo visible se hace presente para nosotros adherido a un cuerpo y a un espacio/ tiempo. Tanto si ha sido vectorizado o rasterizado, reflejado o proyectado, estampado o impreso, trabado o materializado, pasa a ser una imagen para nosotros cuando se muestra como conjunto de datos visuales con posibilidad de sentido; percibidos de alguna manera, escenificados o instalados en algún lugar, y por tanto significados y mediados, dado que "la instalación indica las condiciones de legibilidad, interpretación, afección y percepción con las que esa imagen actúa en cada caso en su confrontación con el espectador; la condición en que se pone a disposición del usuario" (Larrañaga, 2011).

La imagen-materia estaba inscrita en un soporte, encarnada en los cuerpos y las cosas desde las que emergía. Las relaciones y envíos que procuraba provenían precisamente de sus cualidades esenciales de pertenencia y contigüidad. La imagen tenía cuerpo y el cuerpo tenía imagen. Y ambos eran propiamente $s u$ cuerpo y su imagen.

La fuerza de la imagen reproductiva procedía de la constatación técnica de la presencia de materias, elementos y sitios con una apariencia propia que podía ser atrapada. Las imágenes no solo describían sino que autentificaban la pertenencia de una imagen a un cuerpo, la afianzaban como verdadera muestra de aquello que significaba. Había cuerpo y sensación de pertenencia, por lo tanto. De ella tomaba la fuerza de representación, de memoria, de archivo, de retorno. La sensación de movimiento no hizo sino confirmar esta interrelación (Virilio, 1998).

Por su parte, la imagen de síntesis se hace visible en una red de pluricuerpos: El cuerpo de la imagen digital "es" la pantalla del ordenador, el monitor de televisión, los cañones y superficies de proyección, el móvil, las tabletas gráficas, las hojas de grafeno, las pantallas electrónicas de leds... o los sistemas de simulación tridimensional y los hologramas, porque es ahí donde se muestran como imágenes para nosotros. La imagen es tal cuando se usa, se percibe, manipula, difunde, intercambia... Podemos hablar de percepción en la medida en que se hace visible, se aprecia, se capta por cualquier medio. Lo que les diferencia de las épocas anteriores no es la ausencia de mediación sino precisamente su extraordinaria ubicuidad, que les permite insertarse en una multitud de situaciones y disposiciones mediante una extraordinaria 
variedad de medios. Las imágenes electrónicas y digitales se caracterizan por disponer de diversos cuerpos. Porque los dispositivos y materiales no "son", no "pertenecen" a la imagen, ni esta al cuerpo, sino que disponen y están a disposición (Yáñez Tapia, 2007).

No hay una imagen de ordenador, sino una matriz numérica almacenada y procesada en un centro de datos; una matriz que reclamamos, nombrándola, para que tome cuerpo en la pantalla de la computadora que empleamos. Porque ahora las imágenes toman cuerpos.

Ahora se hace evidente que el "soporte" soporta la imagen, es decir, no solo la sostiene sino que la fundamenta, la avala como imagen. Que las técnicas o programas que las permiten hacerse visibles, son medios portadores (Belting, 2007). Y sin embargo, la imagen no "está en otro sitio", solo está donde el usuario la reclama. Es su prototipo, su paradigma, su matriz quien se encuentra en un espacio de almacenaje de números y vectores al que no accedemos directamente.

Imagen que llamamos virtual por su posibilidad, su potencialidad, su eventualidad, no por su "inmaterialidad"; por el contrario una matriz se hace imagen para nosotros cuando se muestra en un soporte o un dispositivo de lectura, que son mucho más complejos y materiales que una delgada hoja de papel o un leve velo, por muchas sustancias adheridas que puedan incluir. Son precisamente los aparatos y medios electrónicos y las pantallas quienes conforman fundamentalmente nuestro paisaje cotidiano, nuestros hábitos, nuestra materialidad y nuestra realidad visual, imaginaria y tangible.

El uso de escáneres e impresoras bidimensionales posibilitaba un circuito cerrado por el que transitaba la idea de imagen a la espera de su materialización, porque desde los dispositivos electrónicos podíamos elaborar una matriz digital que estaba en disposición de tomar cuerpo en su impresión, y que a su vez podría incorporarse de nuevo al mundo digital mediante su escaneado... en un constante bucle. A partir de entonces, el usuario puede partir de una imagen materia para elaborar una digital y viceversa; o incluso abrir un proceso interminable de traspasos entre unas y otras- siempre y cuando se respetara la condición bidimensional y la coincidencia de sus componentes, lo que era sustancial a la imagen materia- se podría decir. Por lo tanto, se trataba de un circuito que actuaba en unos ciertos límites, pero que mostraba un nuevo ámbito de transitividad, donde la imagen podía fluctuar entre la materialidad y la virtualidad.

La invención de escáneres e impresoras tridimensionales ensanchó el circuito de forma determinante. Lo que se ha hecho visible especialmente 
en el mundo del arte. Tanto el proceso de diseño y perfeccionamiento tecnológico como el de especialización y difusión de estos dispositivos, para todo tipo de prestaciones y productos, llevan años desarrollándose a una extraordinaria velocidad. Tienen aplicaciones revolucionarias en todos los ámbitos industriales, tecnológicos, culturales y científicos.

Lo importante no es tanto si seremos capaces de duplicar una obra de arte (parece que sí) sino constatar que la distancia entre imágenes materiales y virtuales se disuelve, en beneficio de una trama de vías de circulación que aún conserva algún obstáculo pero permite el tránsito entre una y otra comprensión de la imagen (Arrault, 2006, pp.23 y sig.).

Cualquiera con conocimientos y medios suficientes puede elaborar una imagen digital o material, poco importa, e incluirla en esta trama transitiva, en la que no solo podrá ser reproducida interminablemente, sino construida tridimensionalmente en una impresora con cualquier tipo de sustancias. Porque el paso entre la materialidad y la virtualidad ya está abierto en todas direcciones. Al margen de su constitución originaria, tanto unas como otras tendrán la potencia de hacerse presentes como materia o como luz, en una extraordinaria pluralidad de condiciones y estados, porque toda estampa es susceptible de ser evaporada en una nube tecnológica transparente o fijada en la conjunción cuerpo/medio que elijamos. Lo que supone una alteración radical de aquello que llamamos imagen.

\section{Transimágenes}

La imagen es número y es materia a su vez, sea cual sea su "origen", porque posee esa potencialidad, esa posibilidad de mostrarse de una u otra forma, y por lo tanto, de ser una u otra imagen, de presentarse en uno u otro estado, en función del uso para el que se le reclama. La invención de los conversores analógico-digitales (fundamentalmente escáneres y cámaras) y de las impresoras tridimensionales (cada vez más precisas), han transformado radicalmente la comprensión de la imagen, tradicionalmente ubicada en alguno de los ámbitos (materialidad, transparencia o virtualidad) en los que parecía se encontraba inserta "naturalmente"; han superado incluso la idea de versatilidad asociada a la reproductibilidad técnica de la imagen, al eliminar la condición de pertenencia a uno de dichos ámbitos.

Ahora tratamos con una transimagen capaz de formalizarse en las circunstancias físicas, las coordenadas espacio/temporales y las condiciones 
perceptivas reclamadas por el usuario en cada momento, por lo tanto no pertenece a uno u otro ámbito. Su visibilidad, su apariencia, su constatación perceptiva se han vuelto ocasionales, coyunturales. Poco importa de qué manera ha sido elaborada- en general en procesos en los que intervienen parcialmente cada una de las tres opciones- porque desde su propia invención, desde su comprensión, ya posee la potencia de hacerse presente aleatoria y/o alternativamente como cuerpo material, proyección o matriz numérica. Lo que le caracteriza es la transitividad dígito-material o matero-virtual (uno de cuyos espacios de intersección es la transparencia).

Transitividad entre dos estados nucleares y sus intersecciones, por tanto. Estamos ante una nueva imagen en constante transacción, por cuanto genera interacciones y comercio de datos y cuerpos que se incluyen ahora en nuestra comprensión visual, en la propia percepción. Una imagen transversal que atraviesa diferentes estados, que se teje en el transcurso de su presentación. Imagen en transición, siempre suspendida, siempre de paso, a la espera de ser llamada, en la posibilidad de una nueva re/presentación. Imagen que se transfiere, se transporta a sí misma como otra cosa, se re/convierte, se transforma, se desfigura y se restaura. Imagen que (se) transcribe en un fluir narrativo. Imagen paradójica por cuanto en su emergencia, en su sustanciación, en su presentación participa de la opinión común y a la vez la niega, la quebranta, la transgrede anunciando que no solo es aquello que se percibe. Imagen en estado de transgresión porque contraviene, vulnera la permanencia, la unicidad, la estabilidad que le eran propias, o más bien de las que (ahora lo vemos) se apropia. Imagen de la cesión y del traspaso y por lo tanto muy alejada de aquella imagen de la determinación, la propiedad y la centralidad, que decía lo que tenía que decir, imagen que hablaba "por sí misma".

Esa potencialidad, esa capacidad transitiva, supone un cambio radical en la comprensión y el uso de las visualidades, que ha abierto un nuevo paradigma imaginario (en/con el que vivimos). La nueva dimensión transitiva ha impregnado nuestra manera de tratar con las formalizaciones visuales. Usamos las imágenes en/bajo esta nueva condición de que cualquier síntesis perceptiva posee la potencia de deshacerse en dígitos, proyectarse en luces de color o conformarse en diversas materias; que puede, por tanto, almacenarse en datos informáticos y recrearse en multitud de cuerpos "que permiten a la imagen acceder a la visibilidad” (Belting, 2004).

Las nuevas transimágenes están en disposición de tomar cuerpo, de tomar 
parte de uno u otro medio, de hacerse sustancia y materia, trasparencia o matriz, de adecuarse a la solicitud, a la convocatoria, al anhelo, en la latencia de mostrarse; tienen la potencia -el brío, la facultad, el poder- de reiterar su presencia y de mudar su formalización, están en permanente situación de paso, no pertenecen a un cuerpo sino que circulan volviéndose diferentes entidades, imágenes atravesadas por cuerpos y suspendidas en datos, matrices numéricas y gráficos vectoriales que se convierten, se vuelcan, se traducen, se derraman imagen.

La comprensión del facsímil impreso en 3D como transcripción, a la que se hacía referencia al comienzo de este texto, se interrelaciona con esta traducción matero/numérica, y es esta combinación la que establece la nueva correspondencia y/o tensión del sentido, de la significación y de la presencia entre diferentes inscripciones o impresiones de la misma visualidad ${ }^{4}$.

La circularidad rompe la dicotomía analógico-virtual, la idea de una visión fragmentada del mundo-imagen, en el que cada una ocupa un espacio propio. No se trata solo de que las imágenes, ahora, "naveguen". Ni siquiera de que viajen en el fluir electrónico en la medida en que nosotros las llamamos desde un "terminal". Lo verdaderamente nuevo, insólito, original y extraordinario es que están navegando y a la vez en varios "puertos". Y además, que la entidadimagen tiene la potencialidad de estar en distintos estados, y de hacerlo simultáneamente.

La imagen materia es ahora una contingencia posible que posee la capacidad transitiva, y una interposición tangible de una matriz o un gráfico vectorial. Es la posibilidad material de toda imagen, igual que la imagen digital es la eventualidad matricial de toda imagen, y la imagen transparencia una de las facultades proyectivas de cualquier imagen. Lo que llamamos imagen (que aquí se ha denominado transimagen para subrayar su nueva condición) se constituye en su uso (elaboración, difusión, percepción, intercambio) y por lo tanto en las condiciones en que se muestra para nosotros. Las nuevas imágenes son entidades abstractas y concretas a la vez (potencialmente ambas), que tienen la capacidad de coexistir en varios estados y varios cuerpos. Son entidades con la capacidad de circular y aparecer en diferentes condiciones, no coordinaciones de estados o de partes constituyentes.

En este ciclo, la transimagen posee una renovada versatilidad que potencia de forma extraordinaria la capacidad adaptativa propia de cualquier imagen y por lo tanto (paradójicamente) le incorpora una enorme carga de debilidad, de desconfianza, de incredulidad, de desafección, al "publicitar" su inconstancia, 
al hacer evidente su falta de sujeción en un estado, en una condición, en una significación. ¿Cómo confiar en una imagen que se nos presenta como verdadera, cuando sabemos que habita una red-imágenes circular en la que puede adquirir cualquier cuerpo, insertarse en cualquier relato y escenificarse en cualquier situación? Porque la condición transitiva no es optativa, sino que pertenece a la imagen.

Esta convertibilidad- que es capacidad adaptativa y mutable a su vezatenúa aún más la particularidad sustantiva de las imágenes. La circunstancia de su elaboración en uno u otro medio deja de ser "esencial" en la medida en que el trasvase corporal ha sido integrado en su propia manera de ser. Tendrá sentido como referencia a uno u otro criterio de presentación, a una u otra experiencia productiva y perceptiva, a uno u otro estrato arqueológico en la historia de la construcción imaginaria y de sus proyecciones tropológicas. Su "insustancialidad" es aún más patente.

La peculiaridad reversible de las transimágenes afecta a su corporeidad y a su forma de presentación perceptiva, no a su escenificación o su significación, su contextualización, al juego texto-visual, emotivo y anímico en el que se muestran como imágenes, en el que se les inserta y al que se adecuan, se amoldan y se supeditan. Lo que hace aún más evidente el papel fundamental de estas condiciones perceptivas en la constitución de aquello que identificamos como imagen- en su caracterización, en su delimitación, en la definición de su particularidad.

La nueva condición trashumante de las imágenes, incluso en su versión más literal- la de aquellas que se insertan en un proceso de clonación, porque las herramientas han adquirido ese grado de precisión que permite una multiplicación exacta, por ejemplo, las instantáneas digitales- no elimina la posibilidad preeminente de una de ellas, a la que podemos seguir identificando y llamando "original", pero no porque posea una dignidad de origen o de identidad, o una propiedad específica que la autentifique y la distinga frente a las demás como ella; no por derecho "natural" sino por asignación, porque establecemos unas reglas de priorización ${ }^{5}$. Es ahora una protoimagen; aquella que posee una cierta prioridad o privilegio en relación a las otras posibilidades de ella misma, una preferencia que puede establecerse en base a su identificación, a su uso e intercambio, a su ubicación socio-cultural, etc. Se trata de una "gratificación" que tiene que ver con su finalidad práctica, con su utilización, y por lo tanto, no se genera desde un supuesto centro de control de la veracidad imaginaria, no está sometido a un único designio o a una mirada cierta y verdadera de lo que se ve en ella, sino que se extiende en la 
pluralidad de aplicaciones y accesos que permiten los nuevos medios en red, con la levedad propia de la proyección, la peculiar persuasión de los datos y la indicación de sentido que caracteriza un formato vectorial.

En esta nueva realidad transmedial y líquida que habitamos, la debilidad de la imagen proviene de la desnudez que indicaba la fotografía, aquella experiencia reproductiva que le había quitado su envoltura a la imagen, haciéndole perder su singularidad y atrofiado y triturado su aura (como apuntaba Benjamin), pero descansa ahora en la transparencia con la que se inserta en los modos de significación, la ductilidad con la que participa en los cruces de mediaciones y la candidez con la que pretende mostrarse omnipresente y autosuficiente.

La nueva transimagen no supone una pérdida de la experiencia sino por el contrario una extraordinaria posibilidad de suscitar y difundir experiencias. Nunca antes las imágenes había generado tal cúmulo de posibilidades y oportunidades experienciales, extendidas y libres. Ahora bien, se trata de una experiencia sin ocupación y sin mandato, abierta a la circulación y a la aplicación libre de cada usuario, que la vive en las condiciones que él mismo establece; la que corresponde a una imagen sin espacio propio y sin marcos prescriptivos. Objeto de distintas experiencias, la transimagen reclama, promueve y ayuda a producir un contexto experiencial en el que habita, contexto que no le pertenece ni provoca por sí sola. Las transimágenes se arriesgan en tramas de acontecimientos, de estados, de significaciones, de disposiciones, que las arropan en una u otra dirección. La experiencia ahora no se acumula en la imagen sino que se enhebra en cada una de sus escenificaciones, donde las imágenes además de verse se tocan en un extraordinario fluir de pantallas manoseadas, y se escuchan, es decir, trasladan al espectador los sonidos de sus actuaciones, de sus excitaciones, de sus envíos posibles y efectivos.

No se trata solamente de una recreación/revisión de su capacidad sinestésica, sino más bien del murmullo en el que las nuevas imágenes "navegan", de las condiciones comunicacionales y mediales en las que se entre-tienen, de las vibraciones y las tonalidades de su discurrir-imagen, de los impulsos y las monotonías en las que se insertan y con las que componen; porque ahora podemos oír y tocar el latir de las imágenes. Un latir que nos acompaña y nos muestra una experiencia y un ver con otros, inserto en la memoria y la experiencia del discurrir propio de la imagen-hoy. 


\section{Notas}

${ }^{1}$ Los datos técnicos del proceso de escaneado, impresión y montaje pueden consultarse en la página: http://www.factum-arte.com/pag/295/Un-facs-mil-de-las-Bodas-deCan--de-Paolo-Veronese

${ }^{2}$ Es decir, en su última restauración (hasta ahora), se invirtieron más de dos años, mientras en su realización, Veronese y sus ayudantes tardaron unos quince meses, y la realización del facsímil ha durado trece meses.

${ }^{3}$ Pueden verse en este sentido los comentarios de Jean-Paul Rioux (1998), coordinador del equipo del Laboratorio de Investigación de los Museos de Francia (LRMF).

${ }^{4}$ Para la reconsideración de la idea de traducción, se han tenido en cuenta varios textos. Ver por ejemplo, (Derrida, 2011, pp. 70 y sig).

5 "El problema del origen se funde con el de las causas, las fuentes, los hechos primeros. Si en el pasado bullen infinitos comienzos posibles para todo, entonces ¿cómo encontrar el comienzo de algo? La palabra origen es inseparable de la idea de Dios: supone el inicio primordial de todas las cosas. La figura de un comienzo se sostiene en la decisión (arbitraria pero no injustificada) de fijar una referencia para pensar (...) Kierkegaard conmueve la fatalidad de un origen al desarmar el orden lógico y cronológico de la repetición: no se repite algo ocurrido, sino que la insistencia, que nos asalta una y otra vez, termina por crear su antecedente arrancando algo de la inmensidad, amarrando una presencia a un recuerdo" (Percia, 2012, p.55).

\section{Referencias}

Arrault, V. (2006), "La barbarie enchantée”, en La création artistique face aux nouvelles technologies (Séminaire Interarts de Paris 2004-05), París, Klincksieck

Belting, H. (2004), "Images trop plein, vide, manipulations, imagerie numerique: à quoi tient la crise de la représentation?", en Telerama 2868.

Belting, H. (2007), Antropología de la imagen, Buenos Aires y Madrid, Editorial Katz

Brea, J. L. (2005), Estudios visuales. La epistemología de la visualidad en la era de la globalización, T.C. Madrid, Akal.

Deleuze, G. (2013), El saber: Curso sobre Foucault, Buenos Aires, Cactus.

Derrida, J. (2001), La verdad en pintura, Buenos Aires, Paidós.

Derrida, J. (2011), "Yo - el psicoanálisis", publicado en Cómo no hablar, y 
otros textos, Barcelona, Anthropos editorial Didi-Huberman, G. (2013), L'image ouverte, París, Gallimard Jay, M. (2004), Campos de fuerza. Entre la historia intelectual y la crítica cultural, Barcelona, Ediciones Paidos ibérica.

Jaschko, S. (2010), La performatividad en el arte y la producción de

presencia, exposición "El proceso como paradigma" en Laboral, Centro de Arte y Creación Industrial, Gijón, España.

Larrañaga, J. (2011), "La imagen instalada" en la Revista Re-visiones 1, p.8:

http://www.imaginarrar.net/descargas/Laimageninstalada.pdf

Metz, C. (2001), El significante imaginario, Barcelona, Paidós

Percia, M. (2012), "Un oído que está por aparecer”, en Blanchot, M. (2012)

La palabra analítica, Buenos Aires, Ediciones La Cabra

Rioux, J.-P. (1998), Revista Techné, 7, p.95

Virilio, P. (1998), La máquina de visión, Madrid, Ediciones Cátedra.

Yáñez Tapia, G. (2007), "Imagen digital: la suspensión de la distancia categorial moderna”, en Revista Estudios Visuales, 5

Josu Larrañaga Altuna: Catedrático de Pintura, Facultad de Bellas Artes. Universidad Complutense de Madrid.

Contact Address: Calle Greco 2, 28040 Madrid (España).

E-mail address: josularranagaaltuna@gmail.com 


\section{$B R: A C=$}

Instructions for authors, subscriptions and further details:

http://brac.hipatiapress.com

\section{La Experiencia de la Metáfora como Alternativa a la Invalidez Digital}

Alejandro Sanjurjo Rubio ${ }^{1}$

1) Artista Digital, Barcelona (España)

Date of publication: June $3^{\text {rd }}, 2016$

Edition period: June 2016 - October 2016

To cite this article: Sanjurjo, A. (2016). La experiencia de la metáfora como alternativa a la invalidez digital. Barcelona, Research, Art, Creation, 4(2), 137-167. doi: 10.17583/brac.2016.1415

To link this article: http://dx.doi.org/10.17583/brac.2016.1415

\section{PLEASE SCROLL DOWN FOR ARTICLE}

The terms and conditions of use, except where otherwise noted, are related to the Open Journal System and to Creative Commons Attribution License (CCBY). The indication must be expressly stated when necessary. 
BRAC - Barcelona Research Art Creation. Vol. 4 No. 2, June 2016, pp. 137-167

\title{
The Metaphor Experience as Alternative to Digital Disability
}

\author{
Alejandro Sanjurjo Rubio \\ Digital Artist, Barcelona (España)
}

(Received: 10 February 2015; Accepted: 7 April 2016; Published: 3 June 2016)

\begin{abstract}
Descartes accelerated the decomposition of the subject, the illustration added impetus to the need to dominate, to control the unpredictable: the outside, the world, the other, reducing the margin of uncertainty, until we were cornered to the invalidation of the scepticism. Without something to refer to and undervaluing the ability to speak and the capacity of give meaning, the subject is the last pitfall, the last obstacle that must be eliminated, that must be eradicated to overcome the unpredictable and eliminate the doubt, the consumption of digital technology triggers a series of behavioural and cognitive processes that crown the paradigm of control. As an alternative into the submission of the binary digit that makes us objects, we have to fit into a predetermined variable, the metaphor arises, understood as a bridge with a look that transcends and ignores the current positive determinism, it resets us, and activates the experience, and the act of experiencing. This paper raises the question of those artistic practices that use digital technology and if with its own spread it triggers our decomposition; it transforms us in pure objects of analysis, blocking a metaphorical look
\end{abstract}

Keywords: Subject, neuroscience, digital art, interaction 
BRAC - Barcelona Research Art Creation. Vol. 4 No. 2, June 2016, pp. 137-167

\section{La Experiencia de la Metáfora como Alternativa a la Invalidez Digital}

Alejandro Sanjurjo Rubio

Artista Digital, Barcelona (España)

(Recibido: 10 Febrero 2015; Aceptado: 7 Abril 2016; Publicado: 3 Junio 2016)

\section{Resumen}

La descomposición del sujeto se aceleró con Descartes, la Ilustración añadió impulso a la necesidad de dominar y controlar aquello impredecible: el exterior, el mundo, lo otro, reduciendo así el margen de incertidumbre, hasta quedarnos arrinconados en la invalidez del escepticismo. Sin referentes, fragmentados, al devaluarse el poder hablar, el poder significar, el sujeto resulta ser el último escollo, el último obstáculo a eliminar, a erradicar para vencer lo impredecible y así eliminar la duda, el consumo de la tecnología digital, desencadena una serie de procesos conductuales y cognitivos que coronan el paradigma del control. Como alternativa a la sumisión al dígito, que nos convierte en objetos necesariamente encajables en una variable predeterminada, se plantea la metáfora, como puente, como una nueva mirada que trasciende y a la vez prescinde del determinismo positivista actual, recomponiéndonos, no para encasillarnos de nuevo en el sujeto aislado, narcisista, vulnerable, sino para creer en la persona que experimenta e interactúa con lo otro. El presente artículo, a modo de ensayo nos lleva a preguntarnos por aquellas prácticas artísticas que se sirven de la misma, y si con su difusión favorecen nuestra descomposición, convirtiéndonos en meros objetos a ser analizados, impidiendo una mirada metafórica.

Palabras clave: Sujeto, neurociencia, arte digital, interacción 


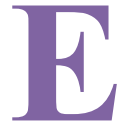

n occidente, la lucha contra el miedo, contra la inseguridad, contra la indefensión ante una bastedad inalcanzable se ha ejercido desde el control, a modo de ensayo, primero los mitos, luego las religiones y por último la realidad exterior. Acorralados en el sujeto, éste se ha convertido en el último eslabón a eliminar. Desde Descartes se aceleró su descomposición, su desaparición, hasta llegar al (pos) postmodernismo deconstructivo en el que el sujeto duda de sí mismo, desconfía hasta el punto de no poder atribuir significados a las palabras, llega a sospechar de aquello que piensa y siente, no pudiendo experimentar experiencias al invalidarlas él mismo, porque ya no es un referente, convirtiéndonos en objetos, en lugar de sujetos, esta incredulidad, esta incapacidad para significar, para crear significado nos obliga a estar encallados en la resignación, nos inhibe en la indiferencia, impide la reconciliación, el reencuentro, la experiencia. El alivio llega en forma de refugio, de distracción, la tecnología digital es más que una herramienta, es un repliegue del sujeto, una concavidad, un escondite de nosotros mismos, relegando nuestras vidas a las máquinas, a las que les atribuimos una humanidad que no les pertenece, nos deshumanizamos en tanto que nos automatizamos, nos convertimos en reflejo de los procesos computacionales.

La irrupción de las nuevas tecnologías aportaron en sus inicios una dosis de optimismo, una esperanza, una credulidad en el sujeto, un retorno a él, al creer que se podría establecer en la red un lugar de encuentro, libre, no sometido a la desconfianza, a la continua sospecha, pudiendo aportar, así, significado, creando experiencias no determinadas por la apatía. Con el paso de los años este optimismo ha ido desapareciendo, para ir comprobando cómo aquel lugar imaginado se ha distorsionado, demostrando que poco tiene que ver con el encuentro soñado, desencadenando una dependencia, un adiestramiento y una homologación que cercena al sujeto; su consumo contribuye, acelera nuestra descomposición, nuestra desaparición. La apropiación de procesos digitales, la digitalización de nuestras vidas, el escaneo constante de nuestras búsquedas en internet, como el uso de los dispositivos y servicios, nos someten a una constante vigilancia, lo que ha ayudado a que deleguemos en el dígito nuestra humanidad, nuestra cualidad como sujetos. Existimos gracias a la dependencia, al valor numérico que nos es asignado por la interfaz, como por la forma y el sonido. Nuestras vidas gravitan entorno al programa informático, 
al imponernos la obligación de acoplarnos al if, al then y al else integrados en sofisticados algoritmos, convirtiéndonos en el objeto que debe encajar, sometiéndonos a los dispositivos y a los servicios que éstos nos brindan, modulando nuestras conductas.

La descomposición del sujeto se acelera al ritmo que imponen los cambios tecnológicos. El pulso cardíaco, como los intervalos entre inhalación y exhalación, los determina la velocidad de conexión, detenernos es una obligación, no sólo por la necesidad de tomar un respiro sino por la responsabilidad de tomar conciencia.

Para luchar contra la descomposición del sujeto condicionada por la era del simulacro, la práctica artística se proclama como el lugar de (re)encuentro desde el que invertir este proceso, desde donde propiciar la metáfora como método, como acceso con el que restituir tanto la experiencia, como a la persona que experimenta.

Es necesario trascender la sumisión digital para trasladarnos a la esperanza de poder sentir(nos). La metáfora es la metodología que nos restituye como personas, creyendo de nuevo que es posible mirar de otra manera, estableciendo la auténtica interactividad; diálogo con aquello que tenemos enfrente nuestro; el mundo. El arte digital ha delegado, al igual que el sujeto, su esencia al dígito, no ha sido capaz de retener su singularidad, cayendo en la evidencia de la base de datos que todo lo relaciona sin fisuras, todo lo encierra en una fórmula matemática que impide la imprecisión, lo impredecible, la vida. No es casual que en la descomposición orgánica y emocional del sujeto, perdamos nuestra capacidad evocadora, seamos totalmente incrédulos y el arte, como ese lugar de encuentro, del que nos servíamos para aproximarnos a nosotros mismos, se descomponga en la mera ilustración de datos, impidiendo que se desencadenen experiencias, garantizando la sumisión a la especificidad inalcanzable, a la obsesiva precisión de la variable que determina lo mínimo, sometiéndonos al control, a lo predecible, a la aniquilación de expectativas, de ilusión, de pasión, verborrea de dígitos que nos somete a la estrechez del cálculo, exaltando el control. La separación entre significado y significante atestigua la imposibilidad de comunicación, evidencia la derrota del sujeto, incrédulo de lo decible como de aquello que se encuentra más allá de lo decible; la cultura de la codificación, de lo descifrable, malmete cualquier opción de conciencia del pasado, presente y futuro. Sólo si nos servimos del dígito con el objetivo de desprogramarnos, con el objetivo de enmarcarnos en la experiencia misma, ofreceremos una alternativa real a la cultura virtual que nos desvirtúa, alejándonos del cómodo victimismo autocomplaciente. 
El arte digital ha de plantear el poderse mecer en la metáfora, reivindicando aquello que es intrínseco a la propia práctica artística, y así ofrecerse, erigirse como alternativa, demostrando cómo desde aquellas mismas herramientas que sabotean e interrumpen nuestra restitución, nuestra recomposición como personas, podamos reencontrarnos con una interacción real y no impuesta por el dígito, pudiendo mirar de otro modo, de manera diferente, reconociéndonos en una relación desacelerada, en la que aceptamos nuestra responsabilidad como personas, enmarcando el diálogo con la realidad.

Ofrecer una alternativa al escepticismo, una esperanza, conlleva reconocer que no hemos de tenerlo todo controlado, que no hemos de continuar abusando de un logos extenuado que busca la dominación de lo impredecible, sino ahondar en una comprensión que no busca en la razón un sentido único. La metáfora entendida como marco, digital o no, nos aproxima a una mirada integradora con la realidad, sana la fisura infectada por el desprecio, por la apatía, por la sospecha. Renunciar es lo opuesto a dejarse engullir por la devoradora oscuridad del exceso. Resaltar algo para restar lo opuesto, diferenciar, es parte de nuestra condición humana, no podemos abarcarlo todo, ni tampoco restar ese todo, ambas situaciones nos colocaría en la indiferencia, argumentar que el funcionamiento de nuestra percepción es una limitación de nuestro cerebro nos denigra y nos encierra en el discurso de la neurociencia que nos precipita a una incredulidad no exenta de juicios de valor. No denota una posición neutra, cada una de las palabras escogidas para describir nuestro supuesto precario sistema perceptivo, llegan a la conclusión de que "el cerebro sólo registra detalles de la realidad, el resto se lo inventa" (Martínez-Conde, 2012), encaminándonos a la peligrosa afirmación de que todo es un engaño, encallándonos de nuevo en el escepticismo, en la culpa, en el lamento, en la decepción, en la desaprobación, en el nada vale la pena porque todo es una gran mentira.

Para que haya un cambio, el todo ha de dejar de ser ese todo (Adorno, 2005), y pasa por el filtro de la diferencia, del significado, de la paradoja. Si caemos en el señuelo de la desaprobación, del escepticismo, nos anulamos al igual que cuando nos instalamos en la oscuridad, pasamos a ser víctimas sadomasoquistas de un mal impuesto, asumiendo el síndrome de indefensión adquirida. Nada se opone a nada, ese es el riesgo que corremos (Brea, 1991), todo vale y es bueno, lo que nos lleva a una absoluta indiferencia, a una absoluta crisis de credibilidad. La auténtica credibilidad no es la de un sujeto racional, estricto, sin fisuras, en el que todo ha de ser como debe ser, absoluta 
ceguera, desatención impuesta, ni la de un sujeto gravitando a su adherido escepticismo egocéntrico, sin ver más allá de su pánico, de su oscuridad que le precipita a la misma ceguera, la auténtica credibilidad es la aparición de la conciencia que contrasta más que el ruido enajenado, es la dialéctica, en la que asumido el miedo, ordenamos y desintegramos en el marco del teatro del significado. Sin telón, sin escenario no hay teatro. Reivindicar la conciencia es una defensa clara de la auténtica credibilidad, de lo ininteligible, de lo confuso perfilado, de lo aún por descubrir, de un cierto ver, intencional con el que discriminamos lo impuesto.

La escenificación "es el lugar de la inquietante extrañeza" (Didi-Huberman, 2010, p. 157), su apariencia pertenece al mismo todo que nos rodea, pero su esencia de como si, es lo que nos recuerda que es una ficción, esa dualidad, esa dialéctica, esa ambivalencia, es el aura de la obra de arte, tiene la apariencia de ser autónoma, de que no nos necesite, pero es todo lo contrario, gracias a que fijamos nuestra atención intencionadamente, debido a nuestra presencia, que brilla más que el resto, sobresaliendo, se desencadena que esa presencia emerja.

El intencionalismo funciona como una lente a través de la que enfocar nuestra atención a la obra, una atención protegida por anteojos para excluir cualquier conocimiento que con el polvo del tiempo se hubiera acumulado sobre la imagen y pudiera distraernos. (Bal, 2002, p. 345)

Escenificar implica crear un potente señuelo que llame nuestra atención, que nos fijemos en él, el cebo alude a nuestro impulso a concentrarnos en algo con tal de contrarrestar el horror del ruido, evidenciando nuestra voluntad a que algo brille por encima del resto, desencadenando un marco que encuadre, una ventana cargada de magia, de teatralidad, sujeta a la experiencia, empírica, de objeto que es y no es, la intencionalidad del foco nos descubre lo que no vemos. Un ejemplo lo tenemos al experimentar las instalaciones de Olafur Eliasson quien no se preocupa por mantener controlado al espectador, al ser la alegoría la que toma el protagonismo, la que expande la interacción, la que hace de mediadora, al ser un puente de cooperación entre lo que aparece, lo que emerge y la propia creencia del espectador a quien no se le ha otorgado un rol pasivo, al contrario, suspende su rutinaria incredulidad para zambullirlo conscientemente en el juego de la extrañeza, de la simbolización, de la evocación. Las instalaciones de Eliasson son experiencias empíricas pero a 
la vez no lo son, ya que aluden a aquello que no son (Adorno, 2004), son un pedazo de lo otro, porque pertenecen al mundo, pero no son algo real, son ficción, al recordarnos que hay algo enfrente nuestro que sirve de pantalla del mundo que ha sido olvidado por la obcecación, por la preocupación obsesiva, por el todo.

Las obras de arte no imitan a la realidad, sino que le enseñan ese desplazamiento $[\ldots]$ Que las obras de arte existan indica que lo no existente podría existir. La realidad de las obras de arte habla a favor de la posibilidad de lo posible. Aquello a lo que se refiere el anhelo de las obras de arte (la realidad de lo que no existe) se le transforma en recuerdo. (Adorno, 2004, p. 180)

La extrañeza, la inquietud, arruinan la seguridad de que el todo es tal como es, porque se transforman en recuerdo de la intención misma, de la mirada, de lo otro, del movimiento, el arte provoca el cambio porque alude a la diferencia que destruye el aplastante todo indiferente, al referirse al mundo, a nuestra presencia en él. El buen teatro, la buena escenificación de Olafur Eliasson nos recuerda que podemos creer en otra forma de interpretar, de percibir, de focalizar nuestra atención, diferente a la cotidiana, redefiniendo, reinterpretando, re-significando el modo de relacionarnos con aquello que tenemos enfrente nuestro; la experiencia empírica en sí misma, invirtiendo la amnesia de un mundo exterior. La tecnología digital con su virtualidad elude cualquier contacto con la realidad, cualquier alusión, ésa es nuestra gran amenaza, al esquivar el recuerdo de que existe algo enfrente nuestro. El sistema binario no busca el desplazamiento, el recuerdo, sino la substitución, la identidad con aquello que se está consumiendo, no evoca, sino que evidencia lo que es, ofreciendo una cura a la expulsión de los vientres de nuestras madres, falsa salvación que nos anula como sujetos, "el hombre cree estar libre del terror cuando ya no existe nada desconocido, lo cual determina el curso de la desmitologización" (Adorno, 2007, p. 31). Eliasson nos despierta del insomnio, de la soporífera ilustración, nos devuelve a lo insólito, defiende erigir una percepción del mundo que dé esperanza al sujeto descreído, harto de sí mismo. Las obras de Eliasson ofrecen paradójicamente lo opuesto a la voluntad universal de dominar la naturaleza, intenta invertir las consecuencias, consciente de que hemos de protegernos de la amenaza de nuestra propia desaparición: 
El dominio universal sobre la naturaleza se vuelve contra el mismo sujeto, pensante, no quedando de éste más que aquel $<<$ yo pienso $>>$ eternamente igual que debe poder acompañar todas mis representaciones. Sujeto y objeto, quedan, ambos anulados. (Adorno, 2007, p. 41)

Los espacios que crea Eliasson no son pasillos, laberintos opacos, de desesperación, de inhibición, de angustia como los de Kafka, en los que el sujeto no pinta nada, no es tenido en cuenta, en donde es rechazado, despreciado, estética de la desaparición, de la descomposición, de un sujeto cada vez más invisible, prescindible, sin que pueda intervenir para revertir su expulsión. Eliasson nos despierta los sentidos, jugando con lo insólito, al crear un ambiente en el que dejar de ver la aséptica cotidianidad, para fijarnos en la densa niebla que todo lo desdibuja y seamos nosotros quienes tomemos las riendas, la necesidad de redibujar lo imperceptible, al fin y al cabo ordenar y desintegrar. Jueces, funcionarios cosificando a sujetos, convirtiéndonos en estadísticas, en números que garanticen balances, gastos públicos, déficits, sujetos sin derecho a ser personas, a pensar, a emocionarse, a incomodarse, sujetos débiles, derrocados, amoldados al puesto de trabajo, a la complejidad del presente, de la norma de que cuanto más tengas más dependerás, como síntoma, como sublimación de la vida de uno mismo, remitiéndonos a un fuerte complejo de inferioridad, desvelando nuestro pánico a perder la vida, volviéndonos cada vez más conservadores, asumiendo nuestro oficio de taxidermistas, conformismo que nos democratiza, que nos iguala en la indiferencia, que nos homologa, que nos estandariza, esa ha sido la recompensa de la lucha por la libertad, un proceso kafkiano, opaco.

La regresión de las masas consiste hoy en la incapacidad de poder oír con los propios oídos lo que aún no ha sido oído y de tocar con las propias manos lo que aún no ha sido tocado, en la nueva forma de ceguera que sustituye a toda ceguera mítica vencida. A través de la mediación de la sociedad total, que se extiende a todas las relaciones y todos los impulsos, los hombres son reducidos de nuevo a aquello contra lo cual la ley del desarrollo de la sociedad, el principio del sí-mismo, se había vuelto: a simples genéricos, iguales entre sí por aislamiento en la colectividad coactivamente dirigida. (Adorno, 2007, p. 51)

La indiferencia es la verdadera ceguera. Olafur Eliasson combate la regresión de no poder oír ni tocar, tiene claro que quien ha de experimentar 
no es él, no es un ejercicio narcisista, sino que ha de ser el otro quien tome un papel protagonista en sus instalaciones. "Las obras de arte se convierten en apariciones en el sentido pregnante, en apariciones de otra cosa, cuando el acento cae sobre lo irreal de su propia realidad" (Adorno, 2004, p. 112). Quien determina ese algo que no existe, que se está gestando, es el sujeto, quien lo expulsa con su interpretación, con su participación, al sentirse mirado (Didi-Huberman, 2010), aludido. "La otredad que entra en nosotros nos hace otro" (Steiner, 2007, p. 112), esa experiencia insólita de las obras de Eliasson, propicia que el todo se derrumbe, para emerger nosotros como otro, como posibilidad, es gracias a ella que nos restituimos, nos recomponemos como sujetos. Lo inquietante, lo indecible, crece, al proclamarse la alegoría. En la obras de Eliasson el sujeto recupera el privilegio, la garantía, la capacidad de poder volver a experimentar, de revelar que es posible disponer de un espacio para la experiencia sin que se corra el riesgo de estar amenazado por la lógica de la deconstrucción, siendo acusado de vivir una mentira que se pudre, viscosa, pegajosa, blasfemia de lo no auténtico, culpa que desencadena una perfecta inhibición, sin referencias, sin mundo, sin sujeto, convertidos en Lord Chandos, descreídos, portadores de una política de la incredulidad.

Eliasson produce por primera vez la pieza titulada Beauty en el año 1993, la instalación consta de una manguera perforada y colocada en el techo del espacio expositivo que está totalmente a oscuras, el agua que contiene se filtra por cada uno de los agujeros, creándose una cortina de agua de gotas imperceptibles, debido a que el diámetro de los orificios es muy pequeño. Sobre la cortina se proyecta un haz de luz, gracias a un foco colocado en la sala, gestándose un increíble arco iris en el espacio a oscuras en el que se ubica la instalación, la variación resultante, el movimiento hipnótico de la cortina de agua, sumado al insólito efecto óptico que se asocia a una experiencia del mundo exterior y no al de un interior sin luz, como el de una sala de exposiciones, se aglutinan para crear una experiencia bella, que nos involucra, que despierta nuestros sentidos, invitándonos a que cartografiemos nuestro estado de ánimo y nos creemos una imagen, una emoción de nosotros mismos, sintiendo nuestra presencia real, nuestra otredad, nuestra diferencia inexplicable, extraña, gracias a la experiencia empírica, real, de algo artificial, prueba de su lealtad con la autenticidad de su esencia. La belleza de la instalación nos traslada a aquello que no es, el recuerdo de lo otro, de nuestra presencia real, olvidada en el resto desechable de la cotidianidad. "Los fenómenos "naturales" siempre aparecen marcados como invenciones, y las operaciones de lo sublime quedan desmitificadas y reveladas, como en 
una demostración científica" (Grynsztejn, 2008, p. 119). Las instalaciones de Olafur Eliasson enmarcan, revelan experiencias de la naturaleza, son ensalzadas gracias a la exageración del contexto en el que son ubicadas, en el museo, en la galería, en el espacio expositivo que nos avisa que lo que vemos es una ficción, fruto de un mecanismo, de algo no auténtico, pero a la vez es natural, real, porque cumple con un principio físico, de cómo la luz se propaga y se dispersa, como consecuencia de la refracción-reflexión-refracción, descomponiéndose en los colores que conforman el espectro, presentándonos el auténtico haz de luz, el foco, la conciencia. Sus obras mezclan credulidad e incredulidad, el hechizo de un arco iris en la oscuridad y el escepticismo de la explicación que descubre el truco del juego de magia, al conocer las leyes de la física que arruinan de una tajada el misterio, es un interesante equilibrio entre la obra que necesita al espectador para que sea interpretada y la obra que le ignora simultáneamente, porque por sí misma es un objeto inmune a la interpretación del fenómeno, peligrando nuestra innecesaria presencia. El equilibrio y el desequilibrio, la aproximación y la distancia nos aseguran el diálogo, el acceso a una presencia; la nuestra, en cambio el arte digital no imita la realidad desde la nostalgia, desde el recuerdo sino que:

La simula a base de generar una semblanza de realidad. En otras palabras, la imitación imita un modelo real preexistente, mientras que la simulación genera la semblanza de una realidad inexistente: simula algo que no existe [...] En contraste con la imitación, que sostiene la creencia en una realidad $<<$ orgánica $>>$ preexistente, la simulación $<<$ desnaturaliza $>>$ retroactivamente la realidad misma al mostrar el mecanismo responsable de su generación. En otras palabras, la $<<$ apuesta ontológica $>>$ de la simulación es que no hay diferencia última entre la naturaleza y su reproducción artificial, es decir, que existe un nivel más elemental de lo Real respecto al cual tanto la realidad simulada como la realidad $<<$ real $>>$ no son más que efectos derivados, y este nivel sería lo Real de la pura computación: detrás del evento que vemos a través de la interfaz (el efecto de realidad simulado) no hay más que pura computación sin sujeto. (Zizek, 2006, 212)

Paul Sermon ensalza la computación sin sujeto con sus instalaciones interactivas, cuya investigación se centra en el campo inmersivo y expandido telemático de espacios, apelando a la participación física y activa para que el espectador deje de ser en apariencia alguien pasivo y juegue a ser un sujeto activamente descreído, el primer paso para lograrlo es que conozca 
el truco; la técnica del croma, Paul Sermon nos lo revela, haciendo creer que ha desnudado el engaño, mostrándonoslo tal como es, desactivándolo. Paul Sermon propicia que espectadores situados en habitaciones separadas se fusionen en una comunicación telemática en el interior de sus respectivas pantallas de televisión que tienen enfrente suyo, ambas habitaciones tienen las mismas características, en sendas estancias hay sofás pintados de color azul para que se sienten quienes intervengan en la experiencia, ambos grupos de personas son capturados por una cámara, para ser extraídos del fondo y así poder ser fusionados, mezclados en la imagen telemática de un sofá de similares medidas pero ya no de color azul, sino cubierto por un tapizado cualquiera, ambos grupos se integran para ser retransmitidos en los televisores que tienen cada uno de los participantes, así entre ellos pueden comunicarse de manera telemática, gracias al croma. Los participantes se ven reflejados en sendas pantallas, junto a desconocidos, sobre un fondo que no es en el que están, que ha sido reemplazado, fascinación pornográfica de yo me veo viendo. Lo emitido en el monitor es el resultado de una cámara directa que lo revela todo, descubre la técnica como quien construye esa nueva imagen telemática, que no existe, ese espacio en común, impostor, en el que los participantes son fusionados, a pesar de estar ubicados en habitaciones diferentes, para que mutuamente se estimulen, se inciten a gesticular, a participar, a comunicarse en un diálogo sordo, sin tacto como el del ciberespacio, un espacio sin cuerpo, desinhibido, sin distinción entre realidad y fantasía, un espacio en que el juego acaba siendo un juego de dominación del otro, y en donde uno mismo se acaba convirtiendo en un objeto que ha de reaccionar a los estímulos que le son telecomunicados. El participante es consumidor de sí mismo gracias a la pornografía que modela la técnica que garantiza que el sujeto sea un objeto; la imagen de sí mismo. Si la técnica del croma se convierte en el protagonista, el sujeto queda apartado, acaba siendo prescindible, al quedar relegado tras el puro exhibicionismo del programa informático que permite la fusión, la telepresencia detiene el vaivén, la diferencia reside en si la técnica es utilizada como motivación o como estímulo, si es un puente para lo imperceptible, o una evidencia, derrumbando nuestra condición como sujetos.

En lugar de estar del lado del objeto visto, la mirada cae en nosotros mismos, los espectadores, razón por la cual la imagen que vemos en la pantalla no contiene ningún lugar, ningún punto sublime-misterioso desde el cual nos mire. Sólo nosotros miramos estúpidamente la imagen que "lo revela todo". (Zizek, 2010, p. 183) 
Para que el poder de fascinación produzca su efecto, este hecho debe permanecer oculto: en cuanto el sujeto toma conciencia de que el otro lo mira (de que la puerta le está destinada exclusivamente a él), la fascinación se desvanece. (Zizek, 2010, p. 190)

Paul Sermon nos demuestra al enseñarnos el truco que nada existe, lo único que sí es real es la computadora, el sistema que posibilita la telepresencia, la invención, la mentira, el otro se fusiona con un entorno evidentemente falso, juegos de presencias exageradas que evidencian el engaño; el vaivén se detiene. La instalación titulada There's no simulation like home es un uno de los ejemplos en los que Paul Sermon descubre el truco para reflejar que la realidad es una construcción del lenguaje, tanto la simulada como la considerada real, nada es neutro, por lo que se instala en la cómoda estética del escepticismo que tiene como objetivo no interpretar sino devastar, estética de la paranoia, de la deconstrucción, del todo es mentira, de la imposibilidad de la experiencia, al no tener garantías, víctimas de nosotros mismos, de lo mentirosos que somos.

Whilst we have become accustomed to accept the existence of ourselves in telepresent forms throughout this installation. We are finally denied the most simple telepresent truth we expect from a mirror, putting the notion of the real and the virtual into question. By representing the domestic reality inside the installation as a fabrication of the technological apparatus outside. There's no simulation like home attempts to present realities as a construct of language. This installation serves as a contextual wrapping for the telematic research and developments used within it. (Sermon, 1999)

There's no simulation like home 1999, consiste en una construcción de un habitáculo que intenta asemejarse al de una casa inglesa, construido en la misma sala de exposiciones, del que sólo se han levantado las paredes, a modo de un plató de televisión, si se ve desde arriba, se observa la distribución en planta del dormitorio, el comedor y el baño, en cada lugar de la casa hay muebles pintados de azul y televisores para que quienes la recorran pueden interactuar telemáticamente con otros usuarios situados en otro lugar de la sala de exposición. Al final del recorrido de la supuesta casa, que desde un principio por la austeridad, por la sencillez se aprecia que obviamente no es tal, y aquí podríamos enredarnos y referirnos al texto de Foucault sobre la pipa 
de Magritte, el usuario se encuentra con un baño en el que hay un espejo, con la sorpresa que es un falso espejo ya que en realidad es una ventana que da a un baño de similares características, de ahí el título de la instalación, poniéndose en duda las nociones de realidad y simulación, pretendiendo demostrar que toda realidad, incluso aquella no digital, es una construcción del lenguaje. Lo que Paul Sermon garantiza es la crisis del significado, de que no nos podamos referir a las cosas y que por lo tanto más vale no creer en las palabras, mejor no fiarse de ellas, como tampoco de las imágenes, como de los sonidos, siendo aconsejable abandonarse a la inhibición del nada vale la pena, o al juego en el que no se diferencia la realidad de la ficción.

Paul Sermon, a diferencia de Olafur Eliasson, muestra el mecanismo que genera la ficción, la fantasía, logrando que pierda su apariencia, para convertirse en obscena realidad. Al utilizar la tecnología del croma con este objetivo impide distinguir entre la apariencia de lo que es real como de lo que no lo es, asegurando el simulacro, Paul Sermon pretende que nos demos cuenta de la esencia de la simulación logrando la nula garantía de la experiencia, y que concluyamos, que nos creamos, que aquello que experimentos no es tal cual es (al no diferenciarse la imagen telemática, de la del falso espejo), asumiendo como natural la para nada neutra sustitución del juego informático, confirmándose la expulsión, la invalidación del sujeto, al ser la nueva naturaleza la propia simulación que ofrece la computadora, la que nos reemplaza y la que nos demuestra que somos una invención, un fraude.

El delator que descubre el truco, acaba propiciando una exhortación de la técnica que asegura, garantiza, perpetua el mito de la simulación, la integra, la ensalza, en lugar de escenificarla, resultando un hiperrealismo del engaño que la hace veraz, la verdad indudable acaba siendo la técnica, el medio, adjudicándole unos valores para nada imparciales, asegurándonos que con la presencia real de la técnica nosotros no pintamos nada, la ceguera es impuesta, dejamos de mirar, de ser tenidos en cuenta, dejando de existir como sujetos para convertirnos en objetos.

Para exagerar aún más la pretendida moraleja y así lograr aleccionarnos con éxito, Paul Sermon compara los usuarios del interior de la instalaciónhogar con los de afuera, con quienes se comunican, los segundos están en habitáculos con iguales muebles pintados de azul pero distribuidos no en habitaciones que pretenden imitar una casa anglosajona ni su recorrido, sino en cubículos desnudos, en los que no se ha pretendido ocultar cables, ni cámaras de seguridad, como intencionada metáfora de que todo es una manipulación, un artificio, creando la evidencia de dos bandos: los que consumen el engaño 
y los que lo crean, para que todavía sea más patente que toda realidad es una construcción, por si aún nadie no se había dado cuenta, la moraleja es que nada es neutro, pero tampoco lo es el descubrir la mentira, el fraude, porque en modo alguno es imparcial. Tanto quien crea la trampa, como quien la consume, como quien la descubre comparten el hecho de actuar movidos por unas determinadas motivaciones para nada puras, vírgenes, neutras.

Si comparamos la instalación de Paul Sermon con la instalación Time Delay Room de Dan Graham construida por primera vez en 1974, teniendo en cuenta que por aquella época no existía la tecnología digital de la que hace gala Paul Sermon, la instalación de Dan Graham comparte con la del primero, en que ambas centran la interacción obra-espectador en base a un circuito cerrado de televisión. La instalación Time Delay Room está compuesta por dos habitaciones separadas por un tabique que no llega a cerrar ambos espacios, conectándolos físicamente y por el que el usuario puede pasar de uno a otro, en ambos ambientes hay colocada una cámara de vídeo vigilancia que registra todo lo que pasa en cada interior. En sendas paredes frontales hay dos monitores de televisión, en uno se puede observar lo que ocurre en la otra habitación y el segundo retransmite lo que pasa en el propio espacio, en el que uno está, pero con ocho segundos de retraso. Esos ocho segundos de retraso son los que convierten al usuario en observador y en observado, posicionándose simultáneamente y de forma extraña en uno y en otro papel, desencadenando la ambivalencia, la ambigüedad, la extrañeza. En cambio, Paul Sermon, desentraña lo semblante, lo que aparece, demostrándonos la fragilidad del edificio, la falsedad de cualquier significado, asegurándonos que no hay nada, afirmando y defendiendo un escepticismo inhibidor, lacerante, en el que todo es una gran decepción en donde no existe nada, anulando el espacio como lugar de proyección de nuestros miedos, de nuestra expulsión, de nuestra presencia como vaivén, impidiendo partir de una realidad física para dirigirnos a una evocada, arrojados a una cotidianidad aburrida, miserable, anulando la diferencia entre realidad y ficción (apariencia), presentándonos la obviedad, de un todo sin fisuras, sin grietas, culminando el proyecto de la Ilustración, del dominio de la naturaleza, de nosotros mismos, un poder que nos sume en la absoluta indiferencia, en la apatía, en la desafección, en la promesa del aburrimiento. Por el contrario Dan Graham, gracias al retraso de esos ocho segundos, a ese breve espacio de tiempo, a esa imposibilidad de observarnos en tiempo real, experimentamos la restauración del recuerdo, de la memoria, de la nostalgia, del poder simbólico, garantizando la experiencia, la observación, impidiendo que nos sometamos a una acción en modo presente 
continuo que desaloja cualquier capacidad de contemplación, de pensamiento, esos ocho segundos son la separación, la expulsión, la distancia que asegura la diferencia, el que podamos continuar proyectando nuestros miedos, que interpretemos nuestra presencia, garantizando que podamos pensar, porque para poder tomar conciencia de la acción, no se ha de estar ejecutando ninguna, esos ocho segundos nos brindan la oportunidad de ir más allá de una realidad cotidiana, insípida, nos sugiere verla de otro modo, propiciando el cambio, variando el modo de observarla, de interpretarla, obligados por lo que no hemos visto, por lo que hemos experimentado, sacudiendo el polvo de la inmovilidad de lo obvio, de lo evidente, de lo que es tal como es. El usuario no puede verse a sí mismo en tiempo real, porque es imposible tener el don de la ubicuidad, abandonar la habitación en la que está, para verse en el monitor del espacio contiguo que emite lo que pasa en la sala que se dispone a dejar, sin retraso alguno, porque siempre acabará viendo la ausencia de quien ya no está, esa imposibilidad, lo que falta, esa incompletitud, sumada a los ocho segundos aseguran la posibilidad, la diferencia, el impulso del vaivén del querer no cejar de pasar de un espacio a otro, por muy absurdo que parezca. Los ochos segundos y el no poderse observar en tiempo real impiden el simulacro, cierto que muestran el peligro de la evidencia, insinuando que todo puede ser una construcción, pero a la vez nos devuelven al marco de la esperanza, de lo inquietante, de lo que no tiene una explicación, garantizándonos nuestra aparición, nuestra presencia, frenándose la amenaza de una niebla que todo lo desdibuje bajo una indiferencia absoluta. Gracias a los ocho segundos y a un espacio que posibilita el transitar de una habitación a otra, pero que impide el que nos podamos observar en tiempo real, enmarcamos la apariencia de nosotros mismos cuando ya no somos, la renuncia, el momento irrecuperable que no se podrá experimentar de nuevo, un ser para la muerte, recordándonos que somos individuos, personas que renunciamos, que experimentamos micro experiencias de la muerte, en cambio Paul Sermon invalida al ser humano, al arruinar la imagen que emerge, al convertirlo en un objeto, al prescindir de él, Dan Graham, restaura al sujeto como persona que experimenta, que interpreta, que hurga en su apariencia.

El arte no puede ser, ha de aludir, sugerir aquello que no es (naturaleza), si no, deja de ser arte, su esencia es ser aquello que no es, Paul Sermon nos dice lo que es, naturaleza del fraude, engaño, construcción, una evidencia que todo lo encierra, creando un todo inamovible rígido, intacto, deteniéndose el movimiento, en cambio Dan Graham establece el diálogo de una presencia que ya no es y que es, creando un inquietante contraste entre lo que ha sido 
y está siendo, algo muerto y que continua vivo, provocando una distancia, un desequilibrio, un movimiento que alude a lo otro. La instalación de Paul Sermon se contrae en la evidencia absoluta de un todo escéptico, desencantado, por el contrario en la instalación de Dan Graham nos expandimos gracias la vivencia de la nostalgia, la aparición de uno mismo en tiempo pasado, presente y futuro. Dan Graham va más allá del lugar, primero contrae la experiencia con la ficticia presencia no real de uno mismo confinado en el circuito cerrado de televisión pero que rápidamente se desbloquea por la desincronía, por el retraso de ocho segundos, es ese intervalo de tiempo el que obliga a que la contracción invierta su inercia y se expanda la experiencia a gran velocidad, dibujando el movimiento del vaivén, meciendo al observador-observado en el desequilibrio de lo incierto, juego entre realidad y nostalgia, contraponiendo emociones, términos, conceptos, significados, encerrando y abriendo, cazando y liberando.

Opposing Mirrors and Video Monitors on Time Delay Room (1974) use closed-circuit video feeds to place viewers in room-scale media installations where they occupy the double role of performer and viewer. Mirrored walls allow visitors to see the reflections of their surroundings, themselves, and a television monitor showing the "just past": the space recorded seconds earlier as seen from the opposite monitor. In Performer/Audience/Mirror (1977), Graham stands on a stage, between mirror and audience, and delivers a series of real-time verbal descriptions of his and the audience's behaviour, creating a kind of self-conscious awareness of present and just-past time. (MOCA, 2009)

La conciencia de presente y de pasado, de uno mismo, garantiza la distancia que invalida el simulacro, Paul Sermon afirma que no hay nada que ver, en cambio al experimentar Time Delay Room, se insiste en la incógnita no resuelta de si hay algo que ver, y la respuesta es sí, manteniéndose el secreto de la apariencia velada, al no resolverse el misterio que la rodea; nosotros mismos, nuestra propia presencia.

Aquellas prácticas artísticas que escenifiquen, han de tener claro que han de remarcar el marco, la diferencia entre realidad y ficción, suspendiendo la incredulidad de la cotidianidad, para que concentremos nuestra atención en un foco iluminado, experimentando algo que se aleje de la rutina y nos recuerde que es posible mecernos, para sentir el vaivén intrínseco a la práctica artística, garantizando el movimiento, el cambio, la posibilidad, que el todo deje de 
serlo, si no, corremos el riesgo que se atenúe el límite, la ventana, el puente, la puerta, el marco, la diferencia.

En la premisa de unir arte y vida el vaivén también corrió peligro, al convertir la vida en arte, o en arte la vida, al pretender disolver el límite entre realidad y lo evocado, dejando pasar la niebla de la ficción hasta enloquecernos, esquizofrenia que impedía diferenciar qué era real y qué no, obligándonos a quedarnos inmóviles, rígidos en la indiferencia de la histeria de la inexistencia, sin cambio, sin movimiento, sin esperanza de ser mecidos, "la barrera que separa lo real de la realidad es por lo tanto la condición misma de un mínimo de normalidad: la locura (la psicosis) aparece cuando esta barrera se rompe" (Zizek, 2010, p. 40), la utopía de unir arte y vida es la misma amenaza de quien pretende arruinar con su discurso la ficción, la fantasía, al acusarlas de inconsistentes, en aras de un realismo del no hay nada más, privándonos de ser los protagonistas de la experiencia misma, impidiendo que se cumpla la promesa de moldearnos y mecernos gracias al movimiento del vaivén, sin él, la condición que nos hace humanos se incumple, nos convertimos en objetos ornamentales, parte del decorado desnaturalizado de escaparates, engullidos por la forma, por el color, por la artificialidad de la estridencia, segura, "arrojados al primer plano, al implacable y voraz imperio de la transparencia comunicativa, en su obsceno exceso de voluntad de mostración, de puesta de todo en un puro orden de visibilidad" (Brea, 1991, p. 37). La híper-exposición nos lleva a que nuestra presencia parpadee, a que los ocho segundos desaparezcan. Sin nostalgia, sin distancia desde la que ordenar y desintegrar, palidecemos, caemos de espaldas, somos muertos de espíritu. Lo que el arte nos enseña, resalta, es que esta extraña ambivalencia, este extraño juego de credulidad e incredulidad no busca culpables, ni redenciones, sino mantener la expectativa, la motivación, la inquietante curiosidad, focalizar la atención en un punto, en una luz hipnótica rebosante de una paradójica esperanza, que nos devuelve la mirada, para ser reconocidos, tenidos en cuenta, sintiéndonos imprescindibles, necesarios, presentes, meciéndonos, aproximándonos a algo intuido, abierto, confiando que verdaderamente vale la pena.

\section{Convertidos en Prótesis Orgánicas de las Prótesis Digitales}

En 2003, el artista australiano Stelarc, logró implantarse una prótesis biológica en su antebrazo izquierdo que replicaba su propia oreja del mismo lado de su cuerpo, sirviéndose de músculos, células humanas y de ratones. Su intención inicial era colocársela en la misma cabeza pero los médicos le convencieron 
para que desistiese por los riesgos que implicaba para su salud. En 2008, acudió a "Mallorca para diseñar con el doctor Ramon Llull un protocolo" (Vallés, 2008) que retocase la réplica implantada. Ya en 2003 los especialistas que le intervinieron por primera vez, contactaron con el doctor Llull para colocarle la estructura de biopolímero con la que replicar e imitar su propia oreja, "material que permite el crecimiento en su interior de tejido" (Vallés, 2008), luego añadieron sobre la plataforma "el relieve y los rasgos necesarios para completar el órgano (lóbulo, trago y hélix), a partir de la implementación de células madre extraídas del tejido graso. Cabe recordar que Llull fue el co-descubridor junto al doctor americano Adam J. Katz de las posibilidades de estas células extraídas del tegumento adiposo" (Vallés, 2008). Durante la segunda operación se despegó el pabellón para colocar un micrófono en la oreja implantada, con el objetivo de que la réplica no sólo oyese sino también retransmitiese lo que capturase, gracias a la tecnología Bluetooth, conectando su cuerpo a internet. Al finalizar la intervención se comprobó su funcionamiento con éxito, pero malogradamente se tuvo que extraer semanas después debido a la infección que le provocó. "The final procedure will re-implant a miniature microphone to enable a wireless connection to the Internet, making the ear a remote listening device for people in other places. For example, someone in Venice could listen to what my ear is hearing in Melbourne" (Stelarc, 2008), dice Stelarc en su página web. Stelarc cree que el cuerpo humano es un organismo defectuoso, obsoleto, desfasado, caduco, que se puede replicar con el fin de mejorar su funcionamiento gracias a la implantación de órganossoftware que operen e interactúen con el mundo, compensando el defecto, ampliando nuestras posibilidades telemáticas, nuestro sistema sensorial.

La artista Orlan declaró en una entrevista al diario The Guardian en julio de 2009 que le parecía anacrónico y ridículo que hoy en día se pudiese padecer dolor físico existiendo fármacos que bloquean la sensibilidad, como por ejemplo la epidural en el parto, o la utilización de opioides en intervenciones quirúrgicas, etc. Orlan entiende su propio cuerpo como un software, "this is my body, my software" (Jeffries, 2009), dijo en la misma entrevista. De 1990 a 1995, Orlan se sometió a nueve intervenciones de cirugía plástica a modo de performance, con el objetivo de utilizar su propio cuerpo como medio sobre el que rescribir, modelar, esculpir parte de la pintura occidental, naciendo, emergiendo un nuevo rostro, un nuevo disfraz, una nueva apariencia, al materializar lo simulado en una pantalla de ordenador, estableciendo un nuevo canon: el electrónico, un modelo; aquello que ha de ser copiado, propiciando un manierismo digital, imagen generada por ordenador que los cirujanos 
se afanaban en imitar, manipulando la materia prima de músculos, venas y tejidos de la artista. Orlan reencarnó, a lo largo de estas nueve intervenciones, el momento del expulsivo digital, al renacer convertida en otra, siendo su cuerpo, en concreto su cara, ese software sobre el que se registraba el collage de la pintura occidental, de los grandes pintores de la historia del arte, la performance conocida como la obra maestra: la reencarnación de Santa Orlan, se convierte en una síntesis de un ideal estético, digital, diseñado gracias a un programa de ordenador. En una operación alteró "her mouth to imitate that of François Boucher's Europa, another changed her forehead to mimic the protruding brow of Leonardo's Mona Lisa, while yet another altered her chin to look like that of Botticelli's Venus" (Jeffries, 2009), imitó "los ojos de Psique, del escultor francés Gerone; la nariz de Diana, atribuida a la Escuela de Fontaineblau" (Gutiérrez, 1997), en 1993 se introdujo dos implantes pequeños que se suelen utilizar para realzar los pómulos, colocándoselos a ambos lado de la frente y que en la actualidad los suele acentuar con maquillaje. Algunas de las operaciones se retransmitieron en directo vía satélite, lo que le permitía comunicarse con los espectadores que seguían la operación-ópera simultáneamente. A lo largo de las nueve intervenciones fue acumulando todo un material documental diverso: vídeos, fotografías, comentarios, textos, dibujos con sangre, restos orgánicos de piel y grasa a modo de "reliquias" (Roldán, 2008), emulando a los exhibidos en iglesias y pertenecientes a santos y a santas, práctica que se remonta a los comienzos del cristianismo, validando la reencarnación de Santa Orlan, material del que se ha servido para sus exposiciones e instalaciones. En 1978 Orlan tuvo que ser intervenida de urgencia con motivo de un embarazo ectópico, Orlan no sólo pidió estar consciente en todo momento, sino que además se le permitiese grabar la operación en vídeo.

What she saw and filmed that day, 31 years ago, inspired her career. Orlan saw the surgeon as a priest-like figure, his assistants gathered around him like fellow celebrants at a Catholic mass. The light from above recalled the heavenly beams that shine down in Bernini's baroque sculpture of Saint Teresa, writhing in religious ecstasy. "For many years, I had appropriated baroque imagery in my work, especially in relation to Catholic art. So when I lay on the operating table, the parallels between the operating theatre and the Catholic mass were not wasted on me. (Jeffries, 2009)

Aquella intervención fue el germen, la semilla para reencarnarse en Santa 
Orlan, para bloquear la sensibilidad de occidente. Hasta hace poco, los inventos o las tecnologías que buscaban la inmersión sensorial, reproducían el esquema en el que se ha basado nuestra forma de interactuar con el mundo y en el que se seguía el modelo de la expulsión del paraíso, como del vientre de nuestras madres; sentíamos que un exterior nos rechazaba o nos integraba, pero siempre gravitábamos entorno a algo externo, ahora el esquema se ha invertido, esa es la auténtica revolución, la inmersión sensorial tiene el origen en el interior, nosotros nos convertimos en la interfaz orgánica de la máquina. Hasta hace bien poco, aún existía una cierta confianza en nuestras capacidades, cierto crédito, un reconocimiento, incluso eran tenidas en cuenta para garantizar la experiencia interactiva, la tecnología, en su literalidad, bajo su aparente falsa neutralidad, tenía como objetivo aproximarnos al exterior. En la actualidad, la perversión, el pliegue, ese puente, esa conexión, ese esquema se está desplomando. La fascinación por la tecnología no puede ser a costa de la decepción, del desengaño de la realidad verdadera.

Stelarc y Orlan centran, sendas prácticas artísticas, en una experiencia connotada del defecto, camuflada bajo una denotada tecnología segura, aparentemente neutra, literal, descriptiva, tal cual es y que funciona bien, perpetuándose un desprecio absoluto hacia la experiencia de sentir, dudando de la fiabilidad de nuestra presencia, desconfiando de nuestra propia condición humana, recomendando desentendernos de nosotros mismos, sugiriéndonos distanciarnos, desconectarnos para alcanzar la promesa de la conexión total, epifanía de la prohibición, de la censura, en la que se condena el mundo sensible como portador del error, como elemento tóxico que interfiere en la exactitud, como virus que infecta nuestra forma de concebirnos, de relacionarnos unos a otros, redundando y reproduciendo la herencia platónica. La intromisión de la desautorización niega cualquier reconciliación, punto de encuentro entre el cuerpo y la máquina, incluso invalida cualquier tipo de interacción con nosotros mismos como organismo que somos, con nuestra realidad más inmediata, de la que sólo nos podemos liberar amputándola e implantándole prótesis, interfaces, esqueletos digitales que nos sostengan. En la inmersión, a la hora de zambullirnos en el juego de la simulación, el que queda desplazado, negado, el que resta rechazado, a un lado, porque es un estorbo, es uno mismo. El arte digital, como las investigaciones que giran entorno a cómo favorecer la comunicación persona-máquina no pueden provocar la ilusión del simulacro, cimentándola en la desilusión de nuestra realidad más inmediata, más cercana; la de nuestro cuerpo. La fascinación por la tecnología no puede ser a costa de la decepción, del desengaño de la realidad verdadera. 
En la medida en que la tecnología es capaz de generar la experiencia de una realidad $<<$ verdadera $>>$, se desdibuja la diferencia entre la realidad $<<$ verdadera $>>$ y la simulación. Esta $<<$ pérdida de realidad $>>$ no tiene su origen únicamente en la realidad virtual generada por ordenador, sino también, a un nivel más elemental, en las imágenes cada vez más $<<$ hiperrealistas $>>$ que nos bombardean desde los medios de comunicación: hoy en día tendemos ya a percibir ante todo el color y contorno, no tanto la profundidad y el volumen. $<<$ Sin un límite visual no puede haber ninguna imaginería mental, o prácticamente ninguna: sin una cierta ceguera, ninguna apariencia se sostiene $>>$ (Paul Virilio, The Art of the Motor, Minnesota University Press, Minneapolis, 1995, p.4.) O como dijo Lacan, sin un punto ciego en el campo de visión, sin un punto elusivo desde el cual el objeto nos devuelva la mirada, dejamos de $<<$ ver algo $>>$, es decir, el campo de visión se reduce a una superficie lisa y la $<<$ realidad misma $>>$ pasa a ser percibida como una alucinación visual. (Zizek, 2006, p. 222)

Debido a la promesa de no ser yo quien interactúe con la realidad verdadera, gracias a la implantación de prótesis, conceptos como los de inmersión, interacción e interfaz quedarán obsoletos. La interactividad de una obra de arte, en especial digital, ya no se medirá ni se caracterizará por el número de pesados e incómodos cascos de realidad virtual, ni por consolas, ni por vídeo cámaras, ni por sensores externos que capten nuestra presencia, en su mayoría interfaces invasivas, ni por entornos de realidad virtual inmersivos como la Cave Automatic Virtual Environment (C.A.V.E.), ni por proyecciones en tres dimensiones, ni por multipantallas, ni por códigos QR que sirvan de puentes a una realidad aumentada, como si la cotidiana fuese disminuida, sino que se medirá por el número de implantes, de cesiones de nuestro cuerpo. Estas diversas tecnologías tienen en común que enfatizan y buscan la inmersión sensorial partiendo del exterior para dirigirse al interior del usuario al que invaden, colapsan y bloquean; es desde el exterior donde se inicia la conquista, sobreexcitando los receptores que capturan y activan nuestra estimulación. Con la aparición de implantes y prótesis se invierte la interacción, siendo desde dentro que se nos asedia, desde donde se gesta la inmersión sensorial, como en Alien, el octavo pasajero, una especie de criatura, en este caso medio biológica, medio digital, nos engulle para ser ella quien gestione el exterior; a nosotros. Nosotros nos convertimos en el soporte de la máquina, antes era el exterior el obstáculo para interactuar con él, ahora somos nosotros el obstáculo que se interpone en la interacción total. No deja de ser curioso que 
la propaganda que acompaña a las obras de arte digitales e interactivas incida en su supuesta propuesta revolucionaria: la implicación del espectador que deja de ser un sujeto pasivo. La experiencia interactiva se nos ofrece como una salvación a nuestra pasividad, a nuestra abyección cotidiana, a nuestra indiferencia, a nuestra inacción, a nuestro desinterés, la interacción se nos vende como la gran esperanza, la redención, la salvación definitiva, la cura a nuestra apatía.

Hoy en día el amenazado por la colonización de las micromáquinas es el cuerpo animal [...] Estas tecnologías van a miniaturizar no sólo el cuerpo, sino sus propiedades. Van a reducir las propiedades del ser vivo bajo el pretexto de complementarlas y asistirlas. Es el mito del hombre biónico, del superhombre nietzscheniano. (Virilio, 2005, p. 57)

La dudas por las posibles secuelas emergen, secuelas por atribuirnos la minusvalía del defecto que nos obliga a necesitar una prótesis-interfaz que nos redima, como por las secuelas que aparezcan tras la intervención quirúrgica necesaria para su implantación, como aquellas secuelas derivadas de la ingesta de fármacos. "Hoy nuestra visión del mundo ya no es objetiva si no teleobjetiva, distorsiona los planos lejanos y los planos cercanos y hace de nuestra relación con el mundo una relación en la que se ven en un mismo plano lo lejano y lo cercano" (Virilio, 2005, p. 83). A la velocidad a la que nos movemos no tenemos tiempo como para distanciarnos, ni para alejarnos lo suficiente como para tener una anotación de nosotros, esa ausencia, esa nada, sustituye la concepción tradicional de registro, las pantallas en la actualidad ya no representan la realidad, no la recogen, no forman una imagen del objeto, la velocidad a la que es reemplazada la información, en tiempo real, en modo presente continuo, impide que se capture algo, que se retenga un registro de una realidad inexistente, evanescente, irreal, es un exhibicionismo de luces, de letras, de sonidos, de movimientos, de imágenes, de flujo, del que no se retiene nada. Para que haya representación ha de existir la posibilidad de registrar en una memoria la experiencia, como una conciencia. El medio ya no inscribe nada, sino que se refleja por él un volumen de información que es imposible de procesar, siendo su valor añadido el consumo por el consumo. Al no existir un espacio ni un tiempo para que se asiente el alud de datos se desata una no-representación, una no significación, una desaparición, una descomposición, que nos condena a una invisibilidad que es suplantada por un mundo virtual, simulado, sin conciencia. La sucesión histérica de imágenes y 
sonidos no convergen en el fondo de nuestra retina, es una excitación absurda, tautológica, que ciega. La función de las pantallas en la actualidad no es la de ser un registro, ese es el papel que se nos ha asignado a nosotros, nuestro cuerpo es quien recoge las ondas electromagnéticas, la inmersión, más que convertir nuestro organismo en un software, lo convierte en un hardware, porque nuestra inteligencia es reemplazada por el logaritmo, por el ejecutable y nuestros órganos por sensores, por microhips, nuestros músculos y tejidos son prótesis orgánicas de las prótesis artificiales, nosotros nos acabamos convirtiendo en la auténtica futura prótesis, en lo postizo. Nos desaprobamos al atribuir capacidades humanas a la máquina, al depositar nuestra total confianza en el software como en el hardware, insistiendo, una vez más en el error cartesiano, reproduciendo la confrontación heredada; la dualidad cuerpomente, trasladada ahora, en la del hardware-software. A menudo se compara el funcionamiento de nuestro cuerpo con el de una máquina, o de nuestra mente con el de un ordenador, equiparando nuestra memoria a la de un disco duro, cuya única función es la de almacenar información; esa visión limitada, restringida de lo que es nuestra memoria y su peligrosa aceptación, ayuda a acelerar nuestra desaparición, nuestra descomposición, nuestra invisibilidad. Estudios actuales demuestran lo contrario. En la toma de decisiones actúa la memoria a corto plazo, o también conocida como memoria de trabajo. Al repetir una misma acción se fortalecen las conexiones neuronales preexistentes, como las sinapsis, ayudando a consolidar recuerdos que posteriormente intervienen en la memoria a corto plazo, influyendo, siendo determinantes en la toma de decisiones diarias. Equiparar el funcionamiento de la integración cuerpo-mente con el de los ordenadores, hardware-software, nos condena a una muerte en vida, la memoria informática no está viva, como tampoco lo están todos los dispositivos y servicios que la rodean.

La neurociencia está llegando a la conclusión de que es un error equiparar nuestro cerebro y en concreto el cómo se acaban formando nuestros recuerdos, cómo se consolidan nuestras emociones, valores, ideas, asociaciones, etc., con un disco de duro, en el que se almacenan y acumulan datos, advirtiendo que el uso del ordenador no es liberador, a pesar de la propaganda, del slogan que intenta convencernos de que los nuevos medios de almacenamiento y de grabación son un sustituto ideal, que nos rescatan, nos dispensan del engorro de retener datos. Se nos dice que gracias a ellos podemos delegar esa cargante y pesada tarea en los nuevos dispositivos, en nubes virtuales, en paraísos de terabytes, pudiendo dedicar todo ese preciado tiempo, todo ese esfuerzo mental que malgastamos en invertir horas y horas en retener y en rememorar 
vivencias, imágenes, información, etc., en tareas más (productivas), más creativas, se nos insta a creer que gracias a los nuevos dispositivos estamos liberados, nos redimimos de nuestra propia condición humana, pudiéndonos dedicar a aquello que más nos plazca: al ocio digital, en lugar de desperdiciar nuestras vidas en acciones tan improductivas como memorizar y recordar. Es imprescindible, para poder imaginar, para poder idear, cultivar la conciencia de una memoria a largo plazo, que se contrasten las experiencias vividas con la memoria a corto plazo. Nuestra manera de memorizar como la manera de concebir la memoria no tienen nada que ver con la de un disco duro, o cualquier otro servicio de almacenamiento de datos, para sentir, para ser sujetos, es imprescindible la conciencia y los ordenadores no la tienen. El señuelo digital, nos seduce para que seamos desertores de nuestra mente, de nuestras sinapsis, de nuestras conexiones neuronales, nos invita a que nos desconectemos de nuestro cuerpo, nos entrena para desentrenarnos, impidiendo una visión integral de la persona.

El uso de la tecnología digital en el arte ha de trascender la realidad digital, remarcar lo ilusorio, incidir en su escenificación, en la ficción que es. Al evidenciarlo, quien experimenta una instalación audiovisual, en algunos casos interactiva, o usa una prótesis-interfaz, se convierte en el protagonista por quien transcurre la metáfora. Al entrar en la instalación, la fe en un todo inamovible, rígido, invariable, se tambalea, se crea la duda, se intuye un otro ficticio, se figura a otro, se evoca. Al abandonar la instalación, la prótesis, etc., se resucita simbólicamente, se deja de concebir el todo como tal, debido a que se ha experimentado la existencia de una alternativa, siendo metáfora del cambio, la persona ya no ve la realidad como antes. En muchos rituales existe esta narración: vida, muerte y resurrección. El uso de la tecnología digital desde el arte ha de procurar escenificar este tránsito simbólico, evitando términos como realidad aumentada, inteligencia artificial, o realidad virtual, vendiendo simulacros de indiferencia.

"Sólo cuando lo que es puede cambiar, lo que es no lo es todo" (Adorno, 2005, p. 365). Aquellas prácticas del arte que se sirvan de la tecnología digital han de luchar contra el todo, como alternativa al simulacro modulado desde el binomio dispositivos-servicios, ampliando y desarrollando las capacidades perceptivas del usuario. Gracias a la esencia ilusoria del arte se nos presenta aquello que no es, la ausencia, lo otro, lo diferente a nosotros, "la epifanía de una presencia real, proclamándose la afinidad del arte con la llamada sobre el misterio en la materia del mundo y el hombre" (Steiner, 2007, p. 255) y en la que se insiste en la "paradoja final que define nuestra humanidad: 
siempre hay, siempre habrá, un sentido en el que no sabemos qué es lo que estamos experimentando y de qué estamos hablando cuando experimentamos o hablamos de lo que es" (Steiner, 2007, p. 240), aquellas prácticas artísticas que se sirvan de la tecnología digital para mediar sus experiencias fracasan si su pretensión es ofrecer una explicación al sentido, porque el riesgo de un todo inamovible, una simulación de un todo absoluto, analítico, aparentemente controlable, a nuestro abasto, lo experimentamos día a día en la rigidez obsesiva compulsiva del binomio dispositivos-servicios.

"Mientras el espectador siga siendo consciente de que está viendo una construcción, será posible un compromiso reflexivo creativo y crítico. Pero si la inmersión es tan profunda que el espectador pierde la distancia crítica, el efecto pasará a ser regresivo" (Coulter-Simth, 2009, p. 49). Supuestamente el tópico de la interacción se contrapone a la contemplación de las obras de arte clásicas al denostar la acción de mirar por ser algo pasivo, negativo, que avasalla, que impone, que impide la participación del sujeto, su reconocimiento, por el contrario se sobreentiende que el arte digital interactivo repara, recompensa esa deuda no saldada por el arte clásico y sí reconoce al sujeto, le da un papel, lo ensalza, el caso es que en muchas ocasiones es lo contrario, si la interacción no manifiesta su apariencia, su diferencia con la realidad, se cae en la inmersión, el sujeto se descompone, desaparece bajo el cobijo de pseudónimos, alias, falsos nombres propios, individuos inventados. En muchas instalaciones interactivas el usuario interactúa con objetos animados, efectos sonoros y visuales que reclaman su consumo y nada más, siendo la estética el auténtico protagonista, la forma, el diseño, el cómo se ve y se escucha, y muy poco o nada la conciencia de la propia experiencia. En el refugio digital perdemos nuestro cuerpo, nuestra presencia, sumiéndonos en un ensimismamiento que mira hacia dentro, un nano-interior imperceptible, que nos distrae y que nos aleja de la conciencia, diluyéndonos en una niebla contaminada.

Esta pérdida de la extensión del espacio real en beneficio del tiempo real es una especie de atentado a la realidad [...] un atentado contra la dimensión real por la contaminación de las distancias [...] La libertad no está amenazada por una prohibición como en la época de Foucault, en la que se encerraba a la gente en una prisión para que no pudieran moverse. Ahora se la encierra en la rapidez y en la inanidad de todo desplazamiento. (Virilio, 2005, p. 58) 


\section{La Validez de la Experiencia como Conciencia de la Auténtica Interacción}

Hay que emerger de la inmersión, restablecer la auténtica interactividad; entre la realidad y lo simbólico, entre el mundo y lo que le atribuimos: tomando distancia, alejándonos, invirtiendo un todo erógeno. No hemos de aceptar morir bajo el logos binario, hemos de interconectarnos de nuevo con la vida, abandonando el aislamiento al que nos confina la inmersión, la falsa interactividad de la interfaz, de la prótesis, del algoritmo que nos impide una visión integrada de nuestro cuerpo y mente. No hemos de inmunizarnos a lo inexplicable, no hemos de bloquear nuestra sensibilidad, nuestro organismo no es una interfaz, ni un hardware, ni un software. En la avalancha de sobre estimulación de la web 2.0 no existe un intercambio real, al ser una comunicación fragmentada, continuamente interrumpida, refugiada en una gramática generativa que nos convierte en parte de un programa de ordenador, una interacción impersonal, anónima, sin espacio, ni tiempo, ni encaje. "Un principio de diseño unificador de UNIX es que un programa desconoce si una persona es la que pulsó esa tecla o si lo hizo un programa" (Lanier, 2011, p. 15). Ese desconocimiento agudiza nuestra innecesaria presencia, nuestra irrelevancia, el hecho de que somos prescindibles. Suspendidos en la inexistencia, ahondamos en la soledad de la fisura, del desencuentro, del desánimo, del abandono, del no ser tenidos en cuenta.

Estamos pagando un precio demasiado elevado por nuestra falta de credibilidad, por nuestra falta de sentido, por el exterminio de la paradoja en sí misma, por la negación de la vida. Nuestra presencia es imperceptible, no es tenida en cuenta, se invalida la necesidad de encajar, la frustración nos envuelve, proyectos como la instalación-digital-participativa, titulada: Almacén de corazonadas del mexicano Rafael Lozano-Hemmer (2006), buscan la restitución, la recomposición de un espacio que nos devuelva la conciencia individual y a la vez colectiva que traspase y vaya más allá de modas y recetas, restituyendo una mirada integrada e integradora del individuo. En la instalación se captura el latido del usuario que visita el espacio gracias a unos sensores, la información registrada es enviada a una de las centenares de bombillas que penden del techo de la sala. Cada bombilla se enciende y se apaga al ritmo de los diferentes pulsos cardíacos capturados. El visitante dona algo íntimo, su latido, con todas las connotaciones que tiene, remitiéndonos a la presencia de uno mismo, al nacimiento, a la vida misma, etc., y lo hace para que lata junto al resto, formando parte de un colectivo. La 
instalación proporciona una experiencia metafórica que trasciende la realidad inmediata para aproximarnos a una mirada y a una percepción diferente de nosotros mismos que nos encaja en un entorno. En su conjunto, la instalación, es tremendamente orgánica, llena de sombras, de texturas, el ritmo resultante tiene obvias referencias con la música minimalista, como con el serialismo musical y en concreto con compositores como Conlon Nancarrow, Steve Reich y Glenn Branca. Gracias al pulso, el control se recupera. La instalación de Rafael Lozano-Hemmer renuncia al exhibicionismo de la tecnología para restituir a la persona, para recomponer su presencia y enmarca la conciencia entendida como acceso a nuestra propia presencia.

No podemos continuar sujetos a la escisión, a la confrontación; cuerpomente, reproducida en la dualidad hardware-software; binomio cartesiano, del sujeto consumido y acorralado, que ensalza un yo hundido, que nos sumerge hacia adentro, inmersión de la que debemos emerger para reconciliarnos con la experiencia, con la vida.

En el campo de la subjetividad no sólo hay un a qué de la angustia, sino paradójicamente también un para qué. La angustia pone algo en curso, y precisamente por ello demuestra ser angustia del sujeto que sabe hacer algo de todo, también de su angustia. La angustia fuera del campo de la subjetividad, en cambio, habrá que representársela como angustia pura, como una angustia sin a qué y sobre todo sin para qué. Está simplemente allí, sin fundamento. No se puede hacer nada con ella. No conduce a nada, no hay ninguna respuesta para ella. Pero a la vez -esto lo permiten intuir los textos de las místicas- emerge allí algo, la posibilidad de otra vida, que no precisaría ya de trascendencia alguna, ni de una trascendencia intramundana, ni de una del más allá. Si esto es así, todo dependería de saber escuchar las, con frecuencia, apenas perceptibles voces de los que intentan hablar desde afuera. Para ello se necesitaría, sin embargo, por parte del sujeto la capacidad de retirarse. $\mathrm{Y}$ esta es en principio y ante todo una cuestión de la praxis, de una praxis que tiene algo que ver con renuncia, con una renuncia no enemiga de la vida. (C. Bürger, y P. Bürger, 2001, p. 340)

Vivir es renunciar, saber renunciar fundamenta esa otra mirada, desde afuera, un modo de mirar no enemiga de la vida. La tecnología digital no tiene la culpa, sino que es el testimonio, el síntoma, el reflejo que denota la exitosa culminación del proyecto de occidente por invertir la expulsión, como su obsesión por el control del que es considerado el principal obstáculo: 
el ser humano. El contexto actual propicia navegar entre dos aguas, entre la metodología cartesiana, en este caso del sabotaje, de la distracción, del gadget, del proceso y la continua sospecha nietzschiana, la perfección del engranaje legitima ambas posturas, permite su convivencia sin que se deslegitimen, ni se excluyan, ni sea considerada una incongruencia alternar y enervar ambos planteamientos. Lo insólito hoy en día es la preñez, la gestación del sentido paradójico que será expulsado, que será ofrecido en vida para su renuncia, para su sacrificio, para su trascendencia, no para una vida más allá, sino para una mirada desde afuera casi imperceptible y para nada enemiga de la vida.

Las zonas multimodales del cerebro pueden dar lugar a un elemento central del lenguaje y el significado: la metáfora (Lanier, 2011, p. 217) [...] En sus formas más severas, la sinestesia es una anomalía neurológica en la que los sistemas sensoriales de una persona están cruzados: por ejemplo, un color puede ser percibido como un sonido (Lanier, 2011, p. 218) [...] El cerebro es tan proclive a las asociaciones que amplificará cualquier posible vínculo por mínimo que sea para conseguir uno utilizable [...] Una buena metáfora surge en una comunidad creciente de ideas que interactúan entre ellas. (Lanier, 2011, p. 219)

La congruencia sólo puede venir desde la experiencia emocional, desde la representación corporal en forma de sentimientos de aquello que se pretende experimentar, exponer, evocar. La paradoja como la congruencia están aseguradas, como la relación yo-mundo, al reconocer ambos lados, ambas orillas, lo interior y lo exterior, la diferencia, el límite. La experiencia metafórica es la experiencia etimología de la trascendencia, del traslado como gesto reparador, diálogo que nos empuja hacia una percepción abierta, que nos abre y nos inquieta, su conciencia nos mece y sugiere el instante de aquello inesperado, ahondando en la necesidad de atender y evocar el extrañamiento que provoca el mundo, aquello que tenemos enfrente nuestro, incidiendo en el diálogo que mantenemos con él, nosotros mismos nos convertimos en el otro a quien dirigirnos, siendo el primer interlocutor con quien dialogar, refiriéndonos, aproximándonos y alejándonos, una experiencia de toma conciencia, de percepción, de memoria, de contemplación. Evocar implica reconocer la alteridad, el mundo, propiciando una mirada integral; interiorexterior, en modo alguna aislada, es una experiencia de la conciencia, momento inesperado, en el que se nos apela a que tomemos presencia, a que no evadamos nuestra participación, auténtica interacción. 
La conciencia de estar percibiendo, como el percibir nuestra conciencia, garantizan el continuar teniendo credulidad, confianza en la memoria, entendida como repetición y no reproducción de nuestras interrupciones. La persona es el protagonista, el medio por el que transita la metáfora, él mismo es la realidad física que trascender, de la que ir más allá, que sacrificar, a quien renunciar para dirigirnos a aquel que no somos; nuestra representación, cómo nos sentimos, cómo nos figuramos, cómo nos reflejamos.

La metáfora no depende de la palabra, ni de la interfaz, ni de la imagen, ni del sonido, ni de la tecnología utilizada, sino de quienes las utilizamos, la pregunta es si aún somos capaces de asombrarnos, de asomarnos al abismo, de quedarnos perplejos y experimentar una duda, una confrontación que todo nuestro cuerpo representa tanto a nivel corporal como mental, una conciencia, una percepción no enemiga, una contemplación que nos sacuda con fuerza, dejándonos casi sin respiración. Más que pretender dar una respuesta, es preferible desencadenar una experiencia y es la de la esperanza, la esperanza comienza evocándola.

La metáfora como experiencia física al implicar un traslado corporalmental, nos transporta al plano de la significación, de la representación, de los sentimientos, se convierte en una estrategia concreta, abarcable, que no nos exige un imposible, depende de uno mismo, de nuestra propia conciencia, como de la percepción del mundo, porque es en el encuentro, en donde se produce la provocación, la experiencia, la relación que desencadena la creación, la preñez, nuestra participación, la representación; nuestro cuerpo, nuestra presencia real, suministra los contenidos que nuestros sentimientos expresan. Es una experiencia que la podemos llevar a cabo, nos recompone, nos restituye, nos repara, nos devuelve la confianza, la autoridad para poder crear alternativas, "revela la conexión al misterio, pero no el principio del misterio" (Damasio, 2011, p. 308). La metáfora desencadena experiencias que enseñan el desplazamiento, el traslado y en modo alguno propicia un discurso que enmascara un gran vacío inmóvil.

En lugar de transformarnos en dígitos, la metáfora nos ofrece la esperanza de lo contrario; la experiencia. 


\section{Referencias}

Adorno, T. (2007). Dialéctica de la Ilustración. Madrid: Akal.

Adorno, T. (2005). Dialéctica negativa. La jerga de la autenticidad. Madrid: Akal.

Adorno, T. (2004). Teoría estética. Madrid: Akal.

Bal, M. (2002). Conceptos viajeros en las humanidades. Una guía de viaje. Murcia: Cendeac.

Brea, J. L. (1991). Las auras frías. Barcelona: Anagrama.

Bürger, C., y Bürger, P. (2001). La desaparición del sujeto. Una historia de la subjetividad de Montaigne a Blanchot. Madrid: Akal.

Coulter-Simth, G. ( 2009). Deconstruyendo las instalaciones. Madrid: Brumaria.

Damasio, A. (2011). En busca de Spinoza. Neurobiología de la emoción y los sentimientos. Barcelona: Destino.

Didi-Huberman, G. (2010). Lo que vemos, lo que nos mira (2a ed.). Buenos Aires: Manantial.

Gutiérrez, L. C. (1997). Vídeo-culturas y ciber-culturas: profanado la pantalla, nuestra mente y nuestros cuerpos. Citado en S. Vilodre, y E. Souza, La estética de los cuerpos mutantes en las obras de Stelarc, Orlan y Gunter von Hagens. Opción, septiembre-diciembre, año/vol. 23, número 054, 114-131. Maracaibo: Universidad de Zilua.

Jeffries, S. (2009, 1 de julio). Orlan's art of sex and surgery. The Guardian. Recuperado de http://www.guardian.co.uk/artanddesign/2009/jul/01/ orlan-performance-artist-carnal-art

Lanier, J. (2011). Contra el rebaño digital. Un manifiesto. Barcelona: Debate.

Lozano-Hemmer, R. (2006). Pulse Room. Recuperado de http:/www.lozanohemmer.com/pulse_room.php

Martínez-Conde, S. (2012, 11 de abril). El cerebro sólo registra detalles de la realidad, el resto se lo inventa. La nueva España. Recuperado de http:// www.lne.es/asturama/2012/04/11/cerebro-registra-detalles-realidadresto-inventa/1226195.html

MOCA. (2009). Dan Graham: Beyond. Recuperado de http://www.moca. org/media/gal_guides/Guide_Graham.pdf

Roldán, J. (2008, 29 de octubre). Orlan: el diseño del propio cuerpo. Los ojos de la filosofía [blog]. Recuperado de http://losojosdelafilosofia. 
wordpress.com/2008/10/29/psicologia-orlan-el-diseno-del-propiocuerpo/

Sermon, P. (1999, 18 de diciembre). There's no simulation like home.

University of Salford. Recuperado de http://creativetechnology.salford.

ac.uk/paulsermon/simulation/statement.html

Steiner, G. (2007). Presencias reales ¿Hay algo en lo que decimos?

Barcelona: Destino.

Stelarc. (2008). Ear on arm. Recuperado de http://stelarc.org/?catID=20242

Vallés, M. (2008, 29 de octubre). Stelarc: el hombre de la tercera oreja.

Diario de Mallorca. Recuperado de http://www.diariodemallorca.es/ secciones/noticia.jsp?pRef=2008102900_16_404826_CULTURApropuesta-artistica-singular-oreja-brazo

Virilio, P. (2005). El cibermundo, la política de lo peor (3a ed.). Madrid: Cátedra.

Zizek, S. (2006). Lacrimae Rerum. Ensayos sobre cine moderno y ciberespacio. Madrid: Debate.

Zizek, S. (2010). Mirando al sesgo. Una introducción a Jaques Lacan a través de la cultura popular (4a ed.). Buenos Aires: Paidós.

Alejandro Sanjurjo Rubio: Artista Digital. Doctor en Bellas Artes (Universidad de Barcelona). Profesor de Bachillerato Artístico y Cap del Departament de Socials i Arts en el centro Jesuïtes Casp.

Contact Address: Jesuïtes Casp. C/ Casp, 25 08010 Barcelona (España).

E-mail address: alex_s@alexsanjurjo.org

Web: www.alexsanjurjo.org 
Instructions for authors, subscriptions and further details:

http://brac.hipatiapress.com

\section{El holograma como Experiencia Artística}

Angel Alonso ${ }^{1}$

1) Crítico de arte y artista plástico, La Habana (Cuba)

Date of publication: June $3^{\text {rd }}, 2016$

Edition period: June 2016 - October 2016

To cite this article: Alonso, A. (2016). El holograma como experiencia artística. Barcelona, Research, Art, Creation, 4(2), 168-186. doi: 10.17583/ brac. 2016.1700

To link this article: http://dx.doi.org/10.17583/brac.2016.1700

\section{PLEASE SCROLL DOWN FOR ARTICLE}

The terms and conditions of use, except where otherwise noted, are related to the Open Journal System and to Creative Commons Attribution License (CCBY). The indication must be expressly stated when necessary. 
BRAC - Barcelona Research Art Creation. Vol. 4 No. 2, June 2016, pp. 168-186

\title{
The Hologram as an Artistic Experience
}

\author{
Angel Alonso \\ Art critic and artist, La Habana (Cuba)
}

(Received: 27 August 2015; Accepted: 4 May 2016; Published: 3 June 2016)

\begin{abstract}
Holography has been used as a way of artistic expression, but it has little presence in art events, neither in articles about holographic woks in specialized magazines are very common, although valuable creators have experienced it, since the catalán Salvador Dalí to the american Bruce Nauman.

This text explorer the cause of this poor presence. It's strange that something so attractive and visually rich (also simbolically) is not visible in our historical moment, characterized by the voracity of convert in artistic resource any possible element.

After research about the development of holographyc on the field of art, I formed a hypothesis about the reasons of their limited presence: The lack of synergy between scientific institutions and those dedicated to art, the disinterest of the commissioners and the lack of information. It is not enough whit the objects that are produced by isolated artists in their studios, art is a system of relationships where the work is involved as an other element of a structure.
\end{abstract}

Keywords: Art, hologram, science, visual, virtual reality 
BRAC - Barcelona Research Art Creation. Vol. 4 No. 2, June 2016, pp. 168-186

\title{
El holograma como Experiencia Artística
}

\author{
Angel Alonso \\ Crítico de arte y artista plástico, La Habana (Cuba)
}

(Recibido: 27 Agosto 2015; Aceptado: 4 Mayo 2016; Publicado: 3 Junio 2016)

\section{Resumen}

La holografía se ha utilizado como medio de expresión artística, pero su presencia es escasa en los eventos de arte, tampoco abundan artículos sobre obras holográficas en las revistas especializadas, a pesar de que valiosos creadores la han experimentado, desde el catalán Salvador Dalí hasta el norteamericano Bruce Nauman.

El presente texto indaga en las causas de esta tímida presencia. Resulta extraño que algo tan atractivo y de tanta riqueza visual (también simbólica) no se haga visible en nuestro momento histórico, caracterizado por la voracidad de convertir en recurso artístico cualquier elemento posible.

Después de una investigación sobre el desarrollo de la holografía en el campo del arte, concluyo con una hipótesis sobre los motivos de su escasa presencia: La ausencia de sinergia entre las instituciones científicas y las dedicadas al arte, el desinterés de los comisarios y la falta de información. No basta con los objetos que produzcan los artistas aislados en sus estudios, el arte es un sistema de relaciones donde participa la obra como un elemento más de una estructura

Palabras clave: Arte,holograma,ciencia,visuales,realidad virtual 


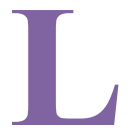

a holografía es una especial técnica fotográfica capaz de representar un objeto en tres dimensiones. Su inventor, Dennis Gabor, estaba interesado en mejorar la resolución del microscopio electrónico y con este objetivo como premisa descubrió, casualmente, un nuevo modo de producir imágenes. El descubrimiento, que tuvo lugar en 1947 y fue registrado un año más tarde en su artículo A new microscopic principle (Gabor, 1948), le proporcionó al científico húngaro el premio Nobel de Física veinticinco años más tarde.

Es con las investigaciones posteriores de Yuri Denisyuk y Emmett N. Leith que puede hablarse de una verdadera representación tridimensional, pues los hologramas de Gabor no contaban con fuentes de luz adecuadas como para que se produjeran los resultados ocasionados por la aparición y el desarrollo del láser (Caufield, 2016). Lo maravilloso de este invento es que superó los límites de la fotografía (su condición bidimensional) para entregarnos una imagen de tres dimensiones que causa la impresión de que el objeto está físicamente allí.

El hecho de que la imagen reconstruida con un holograma sea tridimencional, muestra que este contiene más información sobre la forma de un objeto que una fotografía vulgar. ¿Por qué? Una fotografía común registra solo las variaciones de intensidad de la luz reflejadas por un objeto. Las zonas claras del objeto reflejan más luz y producen regiones oscuras en el negativo. Las partes oscuras del objeto producen el efecto contrario. Un holograma registra no solo variaciones de intensidad sino también de fase en función a la profundidad del objeto (Viera \& Ferreira, 2006)

La tridimensionalidad del holograma prevalece también por encima del efecto óptico de la estereoscopía, cuyos principios se aplican aún en el cine $3 \mathrm{D}$ y que consiste, en esencia, en crear una ilusión de profundidad mediante la visión de dos imágenes planas (una para el ojo izquierdo y la otra para el derecho), casi exactas, solo diferenciadas por la pequeña variación de ángulo visual que condiciona la distancia entre ambos ojos (Fernández, 2004. pp. 120-121). Es probable que muchos confundan lo que ocurre en la holografía 
con lo que ocurre en el cine de tres dimensiones pero en verdad se trata de dos cosas bien diferentes. Cuando vemos una película en 3D distinguimos una sensación de tridimensionalidad a partir de dos imágenes planas, proyectadas por separado pero superpuestas en nuestra percepción. Un holograma es algo conceptualmente mucho más "real", es la traducción de un código encriptado; al iluminarse la placa se proyecta la imagen en el espacio. Esa imagen realmente está allí aunque no pueda tocarse.

El cine 3D crea una ilusión de profundidad, pero al aguzar los sentidos notamos que bajo el hechizo de dicho artilugio no podemos cambiar nuestra posición con respecto al objeto representado. Si desde la pantalla el personaje nos apunta con un revolver el efecto será el mismo para el espectador sentado a la izquierda de la sala que para el que ocupe una silla a la derecha. Si fuese un holograma ambos espectadores tendrían una visión diferente y solo quien se sentase en el centro quedaría apuntado por el arma en cuestión.

Por supuesto, en ambos casos se trata de una sensación de tridimensionalidad en el que mira, pero esa misma alucinación ya germinaba en el uso de la perspectiva como método ilusorio de la Pintura. Estas diferenciaciones ya no las hacemos a causa de nuestra atrofiada capacidad de asombro, esa que desafiaron los hermanos Lumière cuando los asistentes a las proyecciones salían espantados del cine pensando que la locomotora de la pantalla los atropellaría, o cuando los curiosos miraban al dorso de la inmensa tela para ver cual era el truco.

En la holografía, al igual que en la fotografía, se genera una imagen en una película. Solo que la fotografía corresponde a un solo punto de vista y lo que vemos en ella tiene dos dimensiones, mientras que el holograma es un sistema de códigos grabados en una placa que traduce el modelo a su imagen tridimensional, reconoce y abarca toda la información visual que procede del objeto y su contexto, fructifica por el carácter ondulatorio de la luz, por la intersección de sus ondas, se trata de una imagen multidimensional. Es la utopía cubista realizada, al menos en lo que atañe al intento de ese movimiento -verdadera revolución en la historia de la pintura- de representar todas las partes de un objeto.

La utopía se cumple pero mediante un mecanismo opuesto: Los cubistas, en su rompimiento con la pintura tradicional, arrasan con la visión naturalista y establecen la "perspectiva múltiple" (Cottington, 2002, pp.52-60); el pintor no podía desplazarse y unía en un mismo plano varias visiones de un objeto. El holograma nos da la oportunidad de deslizarnos y observar el objeto desde 
varios puntos de vista como si éste estuviese allí en el espacio. El carácter detenido e invariable de una imagen pictórica o fotográfica es desafiado por el holograma, que involucra el movimiento del público, este se mueve y ve otro ángulo de la intangible escultura de luz; a veces está junto a él en su propio espacio, a veces la placa se ilumina y parece un profundo nicho donde está encajada, en ocasiones parece un bajo relieve...

\section{El Holograma en el Panorama de las Artes Visuales; una Presencia Intermitente}

El holograma, con el tiempo, pasaría a intervenir como muchos otros inventos en el terreno del arte. Esto era lógico que sucediese, pues se trata, más allá de sus valores como avance científico, de una forma de construir imágenes. Desde este punto de vista, se esperaba que ocurriese lo mismo que a la fotografía o al cine, este último considerado hoy el Séptimo Arte, aunque en sus inicios fuese un entretenimiento de feria. No es un secreto que los artistas visuales han sido sumamente abiertos al asumir como materiales de producción todos los medios imaginables. La Video-creación, el Performance o el Arte Digital, son algunos ejemplos de la trasgresión de los lenguajes tradicionales. Obras elaboradas con luces, sonidos, textos, olores... dan fe de la capacidad del Arte Contemporáneo para concebir como posibilidad expresiva cualquier elemento de la materia y hasta de la no materia -recordemos los espacios vacíos del artista francés Yves Klein intercambiados por oro-. "un intercambio simbólico entre el máximo valor material y el mínimo” (Dueñas, 2001).

Se han liberado las fronteras entre las diversas manifestaciones artísticas y hasta las más rancias academias incluyen en sus programas de estudio disciplinas inherentes al uso de los ordenadores como el llamado Net Art. -aquel que opera en Internet hurtándola como escenario para su disfrute y consumo- o el Arte Interactivo -que rompe con la pereza del espectador por tratarse de obras de participación-. Los cursos de Historia del Arte ya no se detienen en el pasado y relatan experiencias coetáneas que devienen, en la mayoría de las ocasiones, del Arte Conceptual pero que no son fácilmente clasificables. Asistimos a un momento histórico en el que el artista escapa a las ya infuncionales etiquetas de los críticos a causa de sus infinitas posibilidades. El panorama, que pudiéramos calificar de cósmico por su diversidad, es inclusivo, depositario de las más osadas mezclas y ajeno a los radicalismos de las vanguardias del Siglo XX, se trata de un reflejo de la fusión que caracteriza 
nuestros tiempos, un fenómeno que se manifiesta en todos los ámbitos de la creación artística y del pensamiento en general. A pesar de esta actitud tan desprendida de normas y tabúes, no encontramos con frecuencia hologramas en las galerías, como tampoco en los más importantes eventos de las artes plásticas.

Los artistas de principios del Siglo XX estuvieron fascinados con la industrialización e incorporaban a sus obras los progresos de la mecánica -la pintura de Fernand Leger es representativa de esta tendencia- pues cada técnica que nace es absorbida y reelaborada como recurso estético. "A Leger le preocupaba dar cuerpo al concepto de un Nuevo Realismo alternativo. Según él cada época artística tiene su propio realismo" (Fer, Batchelor, \& Wood, 1999, p. 264). Los creadores de hoy están tan hechizados por los avances tecnológicos como aquellos que en el ayer se apasionaron con las máquinas. En el cine Fritz Lang (Metrópolis) o Charles Chaplin (Tiempos Modernos) trataron el tema, mientras que en el ámbito de las artes plásticas Francis Picabia y Marcel Duchamp incorporaban el dibujo técnico a sus obras. Era ésta una manera de eludir el placer de la retina y desarrollar el camino inaugurado con la racionalidad matemática de Seurat (luego el historiador del arte Filiberto Menna, estudioso del arte moderno, lo acuñaría como "opción analítica" (Menna, 1977). Con el mismo ímpetu los artistas contemporáneos utilizan las ventajas del mundo digital e incorporan a sus obras vídeo juegos, sensores que generan sonidos y cada recurso que ofrecen los llamados "nuevos medios".

Sin entregarse totalmente a esta técnica, pero incursionando con seriedad en ella, no son pocos los artistas que han realizado hologramas. El catalán Salvador Dalí pretendía superar el relieve pictórico que creía encontrar en las pinturas de Gerard Dou. Cuando Gabor obtiene el Premio Nobel, el artista se había adentrado en la construcción de imágenes estereoscópicas y también había intentado diferentes procedimientos ilusorios como las imágenes dobles. La obra Rostro paranoico (1935) es un ejemplo de su método al que llamaba paranoico-crítico, en ella representa un rostro construido con figuras humanas en un paisaje. Es a partir de este descubrimiento que Dalí se sumerge en su pasión por trascender las limitaciones que encuentra en las dos dimensiones de la pintura. En 1972 la Galería Knoelder de New York exhibió una muestra de sus primeros hologramas (Dalí, 1972). El propio Gabor asistió a la exposición, en la que se vio representado por el entonces inquieto surrealista. Célebres son los hologramas del norteamericano Bruce Nauman, su serie Making Faces (1970) proyecta al artista constriñendo su 
rostro para evidenciar la condición matérica de su carne. Para Nauman este trabajo es una meditación sobre el cuerpo como material (Sharp,1970, pp. 2227). Resultarían imprescindibles en un recuento histórico las obras del escultor francés Maurice Dyens, sobre todo aquellas en las que mediante un ordenador integra diversos lenguajes incluyendo el de la holografía. También han sido muy importantes sus contribuciones para documentar el trabajo realizado por otros artistas, como destaca José Luís Pérez.

En cuanto a lo que se refiere al arte holográfico, el escultor francés Maurice Dyenses es uno de sus máximos exponentes, siendo el responsable de la elaboración en 2002 de la primera y única Enciclopedia Internacional de arte holográfico que está disponible en CD-ROM e incluye los trabajos holográficos de más de un centenar de artistas. Otros artistas que han destacado en este tipo de arte son Moysés Baumstein y los españoles José María Yturralde y Pepe Buitrago (2015).

Otros creadores se han adentrado más en estos procesos como medio de expresión. Los hay muy reconocidos como es el caso de Dieter Jung, artista alemán que ha sido uno de los pioneros en la aplicación de estos medios (Huo, 2010). Bajo una concepción cinética, casi siempre vinculada a la abstracción y a veces incluyendo la figura humana, Jung nos hace partícipe de sus ingeniosas y cambiantes composiciones. También el finlandés Reima Nurmikko se ha destacado por sus obras llenas de humor y sagacidad (Benton, Greguss, Huhtamo, Kac, \& Koski, 1999). Una de ellas, titulada Up and down (2013), exige del espectador flexionar las piernas para ver la segunda de las dos imágenes contenidas en la placa -esto ocurre sin ninguna exhortación escrita al pie de la obra, el público simplemente lo hace en busca de una mejor visión-. En Australia es pionera de estas técnicas Paula Dawson, quien se destaca por sus hologramas de gran formato (Starick, 1995, p. 8). Margaret Benyon es considerada la madre de la holografía británica, comenzó su trabajo a finales de los $60^{\circ}$; estos trascendían el interés puramente científico y fueron valorados como obras de arte (Johnston, 2006). 

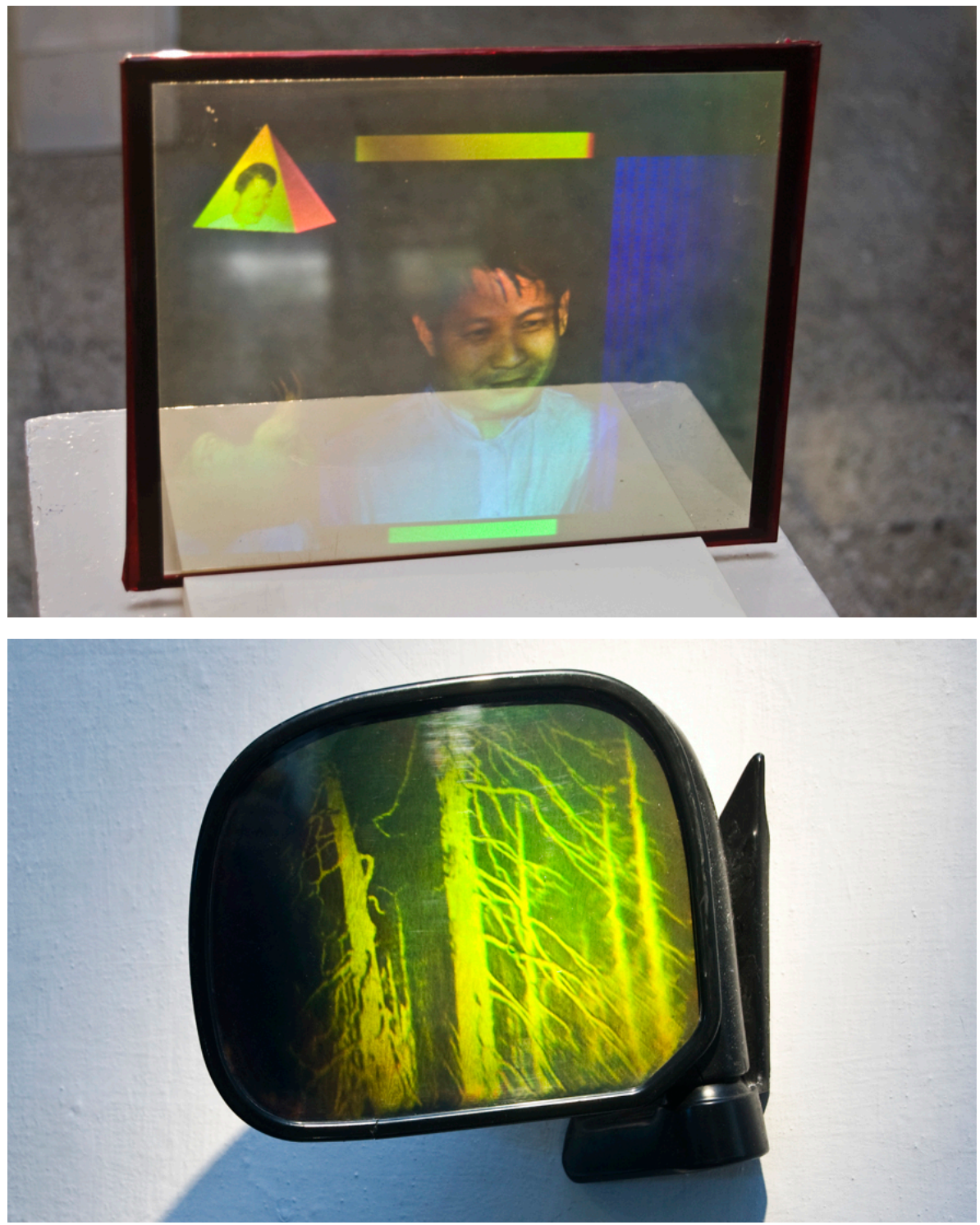

Figura 1. Holograma "The Art Collector" (2013) de Dieter Jung, Fotografía de Alain Cabrera

Figura 2. Holograma "Objects are closer than they appear" (2013) Reima Nurmikko. Fotografía de Alain Cabrera 
Resulta complejo determinar el grado de inmersión con que cada uno de estos artistas ha explorado la holografía para incorporarla a su obra. Desde los que la han utilizado puntualmente (como Nauman) hasta los que han profundizado en ella convirtiéndola en su principal medio de expresión (como Jung), las experiencias han sido disímiles y entremezcladas con el conocimiento adquirido en la práctica de otros lenguajes más tradicionales. Jung no habría sido capaz de hacer sus hologramas abstractos sin un conocimiento previo de la pintura y la escultura, su cinetismo procede de la influencia de artistas cinéticos como Alexander Calder y otros. No contamos con una tradición del arte holográfico al mismo nivel que sí existe una tradición de la pintura o de la escultura, de ahí que no haya un artista del holograma "químicamente puro", todos se expresan o se han expresado en otros lenguajes e incorporan lo aprendido a sus obras holográficas bajo la influencia de la Historia del Arte. Lo que tienen en común muchos de ellos es que son artistas que trabajan a partir de sus ideas y no a partir del medio. No son "máquinas de pintar" ni tampoco "artesanos del holograma", son creadores que buscan el medio más adecuado para expresar sus ideas, y el uso de la holografía ha resultado el más eficaz para algunos de ellos mientras que otros lo han necesitado para obras muy puntuales. No hay entonces una relación directa entre el número de hologramas que realicen y el valor artístico de los mismos, pero llama la atención que son escasos los que convierten esta técnica en su principal recurso expresivo. La producción artística de un período histórico suele encarnar el espíritu de su tiempo asimilando los avances tecnológicos del mismo; en nuestros días nos adentramos, cada vez más, en un mundo de simulaciones que no difiere demasiado del efecto óptico que nos provoca el holograma.

Por asociación a los efectos de la realidad virtual -esa apariencia de veracidad generada a través de los ordenadores- que ha puesto en crisis la barrera entre realidad y ficción, se ha utilizado erróneamente la palabra holograma, pues se ha empleado el término para designar otras proyecciones de apariencia tridimensional. El error se ha extendido al punto de naturalizarse; esto denota una generalizada irresponsabilidad de la prensa (también de la prensa digital) y un vasto desconocimiento de lo que es un holograma en su aspecto tecnológico.

\section{Obstáculos para el Desarrollo de la Holografía en el Arte y sus Posibles Soluciones}

Uno de los factores que atenta contra la popularización de este medio entre 
los creadores es la desinformación. La única referencia a esta técnica con la que cuentan muchas personas es aquella escena de la película La guerra de las Galaxias, cuando la princesa Leia pide ayuda desde una primitiva imagen tridimensional. Esta grabación se repetía como en un disco de vinilo dañado -"Ayúdame Obi Wan Kenobi, tu eres mi única esperanza", (pausa) “Ayúdame Obi Wan Kenobi..." y así sucesivamente-. Lejos estaba George Lucas de imaginar que solo unas décadas después -el filme lo realizaría en 1977-, el adelanto tecnológico superaría con creces, tanto en calidad y definición de imagen como en color, aquella predicción. En Japón, por ejemplo, investigadores de las universidades de Tokio y Osaka, han logrado avances en la producción de hologramas a color que se generan con una común fuente de luz blanca en vez de con láser, una técnica que se diferencia mucho de la holografía tradicional y permite la reducción de costes (Ozaki, Kato \& Kawata, 2013, pp. 6788-6791).

Construir un taller de hologramas puede estimar un gasto de miles de dólares y esta es una causa importante de que estas técnicas no se hayan popularizado, también es cierto que se trata de un procedimiento que requiere un largo aprendizaje. Aún así los costos de fabricación de un holograma están muy por debajo de los invertidos en muchas obras de arte contemporáneo y el artista no tiene que conocer a fondo el proceso técnico del holograma si cuenta con la colaboración del científico para la producción de este tipo de obra.

El trabajo holográfico que hemos citado de Bruce Nauman no hubiera sido posible sin el apoyo de expertos en esta técnica, tampoco Dalí realizó sólo sus hologramas. No es imprescindible, para considerarle autor de una obra holográfica, que el creador haga todo el proceso técnico. Artista es quien crea, quien diseña la imagen, quien emite un discurso artístico a través de un objeto (en este caso) que puede ser elaborado por él mismo pero que también, como el edificio que proyecta un arquitecto, puede ser fabricado por otros. El impresor de un taller de grabado, por ejemplo, garantiza la calidad de la impresión y a menudo posee conocimientos más profundos de los procesos técnicos que el artista que ha dibujado en una piedra litográfica, o que ha grabado la matriz de una xilografía, pero es el artista quien firma la edición. Del mismo modo, la holografía aplicada al arte requiere del intercambio y la colaboración entre disciplinas diferentes, entre el científico y el artista. Este es el aspecto más enriquecedor de esta experiencia porque el artista aprende de física, de óptica...y el físico a su vez se compenetra con la imaginación del creador. 
Por otro lado un holograma convencional como los llamados "de transmisión"-en el que la imagen de luz se encuentra al otro lado del espectadoro "de reflexión"- aquel que toma forma del mismo lado de la placa donde se encuentra el observador- no es más costoso que muchas de las instalaciones expuestas en los eventos artísticos o que muchos murales públicos financiados por ayuntamientos de diversas comunidades. Obras de artistas altamente reconocidos como las de Christo y Jeanne-Claude (Chiappiani, 2006) se llevan a cabo con elevados costos de producción. Solo por poner un ejemplo: para su proyecto "Valley Curtain" (1970-1972), consistente en una tela de 400 $\mathrm{m}$. de largo desplegada sobre un valle, los artistas tuvieron que reunir 230.000 dólares norteamericanos.

Muchos pintores o escultores emergentes sacrifican altas sumas de dinero en contratos anuales con galerías por conceptos de representación, y lo hacen más por ganar un poco de visibilidad que por lo que puedan adquirir con la venta de sus obras. No son pocas las convocatorias de bancos y otras instituciones que disponen de presupuestos suficientes para la ejecución de costosos proyectos. En su Convocatoria del año 2015 Ayudas Fundación BBVA a la Creación en Videoarte, el Banco Bilbao Vizcaya Argentaria estimulaba a los creadores audiovisuales participantes con una dotación de 30.000 euros para la producción de cada una de las 10 obras ganadoras. Algunas de estas ayudas económicas podrían destinarse a financiar la producción de hologramas artísticos, pero ni siquiera se toma en cuenta tal posibilidad, es una zona de la creación extensamente ignorada.

Existen además técnicas muy sencillas de producir un holograma, entre ellas una muy antigua en la que solo se requiere una lámina de acetato o acrílico y una punta de acero (Beaty, 1995). El resto del éxito corresponde a la destreza del artista que manipula estos sencillos instrumentos y a la concepción de la obra. Este método de hacer hologramas a mano es anterior al invento llevado a cabo por Dennis Gabor. En 1934, el artista Hans Weil había patentado un procedimiento para hacer dibujos de luz que parecían flotar en el espacio (Abramson, 2000).

La precaria técnica, que sería luego conocida como Holografía incoherente, es un precedente del holograma tal como lo conocemos hoy. Una fuente de luz puntual procedente de una lámpara produce un destello en una ranura trazada con una punta de acero sobre la superficie empleada (Weil utilizaba láminas de metal). Si el artista ha dividido las líneas de su dibujo en puntos y hace centro en cada uno de ellos por cada arco que traza -en la misma dirección y 
con similar profundidad-, entonces los destellos se unirán organizadamente en su visión y esta línea de puntos brillantes le devolverá el dibujo original en forma de holograma.

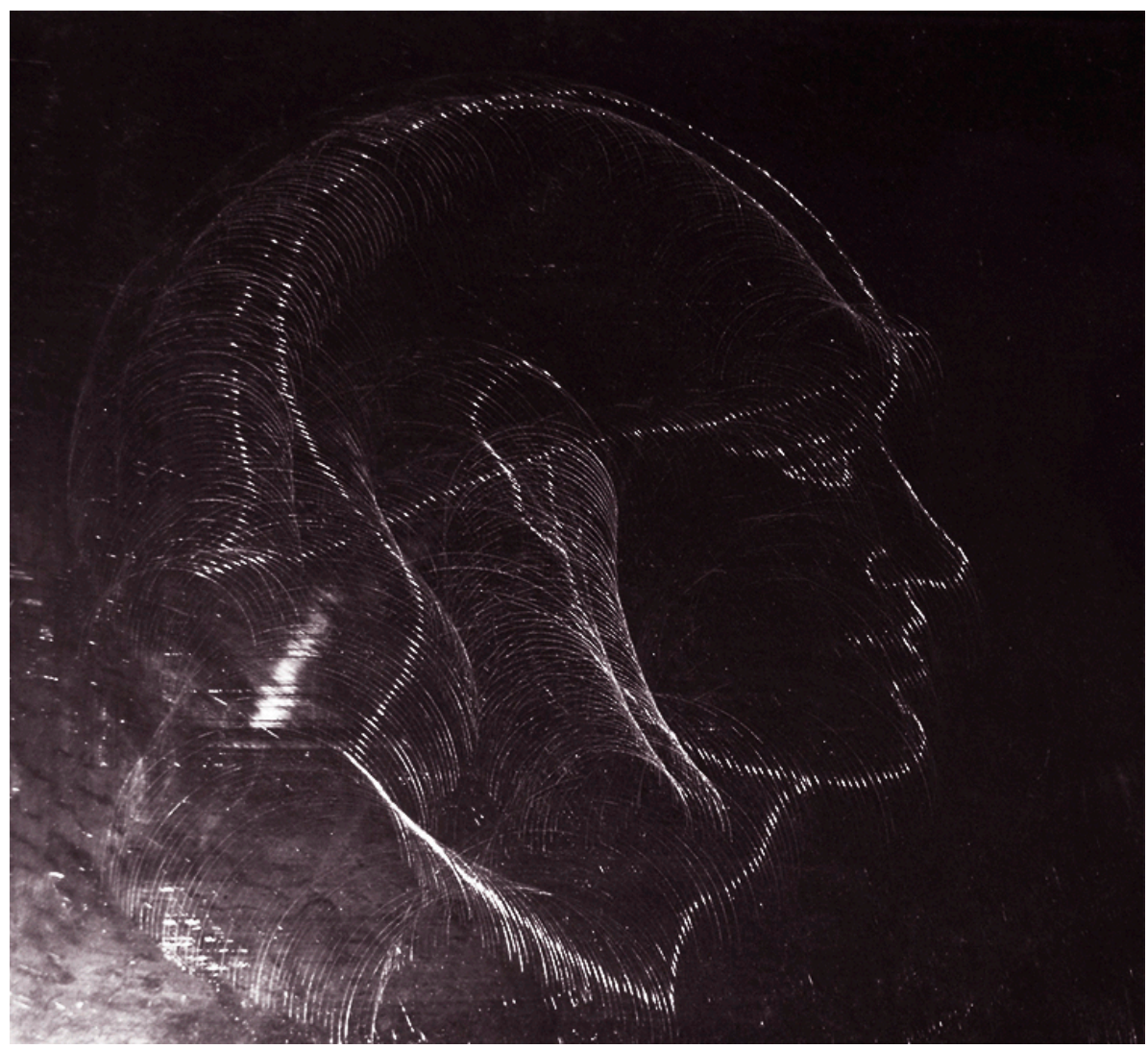

Figura 3. Holograma hecho a mano "Yo no quiero ser un soldado" (2012) de Angel Alonso, fotografía de Alain Cabrera. http://angelalonso-artist.blogspot.com.es/

En 2009 se creó en Cuba una nueva tecnología que constituye la generalización de estos hologramas. En este caso se elabora previamente un diseño en ordenador que es codificado y grabado con láser sobre un material conveniente, lo que permite su aplicación como grabados holográficos, con 
amplias posibilidades como herramienta artística. Sus creadores fueron Ángel G. Augier Calderín y Raúl B. Sánchez. "La creación de esta tecnología e introducción de este tipo de hologramas, generados por ordenador y grabados directamente con láser, ensancha las técnicas holográficas existentes, instaurando nuevas posibilidades de aplicación." (Augier, 2013, p. 14)

Es frecuente encontrar hologramas de alta calidad técnica en los museos históricos, su destino como reproducciones es sustituir valiosas piezas reales en las salas de exhibición y este carácter mimético está lejos de las funciones de la obra de arte. La holografía ha llegado a ser considerada un medio de expresión artística más, aún cuando no se haya popularizado como tal. Arte, ciencia y tecnología se han tomado de la mano a través de los tiempos, no solo a partir del Renacimiento -hemos trascendido la posición de apreciar el fenómeno desde la hegemonía occidental- sino desde mucho antes y en todo tipo de sociedades, antes de que estos términos se acuñasen.

Además de la desinformación y las complejidades de tipo económico hay otro factor que atenta contra el uso del holograma en el terreno del arte, se trata de la abundancia de imágenes a las que nos sometemos continuamente, Con la constante mirada a las pantallas de los celulares, el frecuente uso de los ordenadores y otros dispositivos, asistimos a una visualidad tan cargada de imágenes impactantes que nos saturamos de las mismas y no discernimos entre ellas.

A estos factores se suma otro también importante y es la escasa presencia de críticos, curadores y organizadores de eventos artísticos que trabajen en la promoción y difusión de estas obras. Resulta paradójica la tímida presencia de imágenes holográficas en las exposiciones al mismo tiempo que asistimos a un momento histórico tan desprejuiciado, tan proclive a aprovecharlo todo como el del arte actual. En el caso de las bienales contamos con escasa presencia de Arte Holográfico. Un ejemplo interesante es el del artista Shu-Min Lin, quien expuso en el pabellón dedicado a Taiwán de la $49^{\mathrm{a}}$ Bienal de Venecia que tuvo lugar en el año 2001. Su obra titulada Glass Ceiling (1997) consiste en hologramas de personas de más de 40 países colocados sobre el suelo de modo que el espectador puede pisarlos. Las personas están mirando hacia arriba y el espectador camina sobre ellas. Para el artista se trata de hacernos sentir malvados al caminar sobre otras personas, una metáfora de la competitividad de nuestras sociedades (Haupt \& Binder, 2001).

Hay una generalizada indiferencia al tema que aquí tratamos por parte de las instituciones que provienen del mundo del arte y por parte de los promotores del arte. Podemos encontrar textos que hablan del holograma redactados por 
especialistas en física, en óptica...que se publican en revistas científicas, pero no abundan textos elaborados por críticos de arte o comisarios de exposiciones, que contengan una visión de la holografía desde sus posibilidades como medio de expresión artística o que vean la luz en catálogos y libros de arte. No nos llegan a menudo (tampoco a través de las más circuladas revistas de arte) noticias referentes a artistas plásticos que se expresan por medio de hologramas. La falta de interés tiene que ver con la ausencia de un mercado de arte que promueva este tipo de obras, difíciles de vender, no tanto por sus condiciones físicas o de iluminación como por su falta de legitimación en el campo artístico.

Un poderoso mercado capaz de convertir en fuente de dinero desde a una artista de la performance como Marina Abramovic hasta las ideas heredadas de Joseph Beuys, que se las arregla a través de la documentación para vender obras que ni siquiera existen en el plano físico, no ha sido capaz de atrapar en sus redes -ni de estimular- la producción de un arte holográfico. Salvo contados ejemplos no se han incorporado a las salas de subastas estas obras y permanecen casi ajenas a los mecanismos de comercialización.

La holografía sigue habitando mucho más en el terreno científico que en el artístico, y mientras la misma no se naturalice, el artista que hecha mano a este medio corre el riesgo de quedarse en los pantanos de la gratuita experimentación formal; al menos la recepción del público tiende a ser esa cuando el creador utiliza medios poco conocidos. No toda la responsabilidad de la ausencia de difusión de un arte holográfico recae en las instituciones, los comisarios o el mercado; lo atractivo de las imágenes holográficas puede resultar también un elemento en contra de la efectividad de su uso. En el proceso de incorporación de un mecanismo de representación no convencional a su aplicación como medio de expresión hay una etapa de experimentación que ha de ser trascendida, de otro modo no puede explotarse el mismo en toda su potencialidad.

Así ocurrió con la fotografía, primero utilitaria, luego cada vez más utilizada como medio artístico. En el caso del holograma sería bueno realizar una investigación más amplia, que nos diese las claves de cómo es que un medio tan rico, tan especial y lleno de magia, tan susceptible a la elaboración de propuestas interesantes, se encuentra tan relegado, casi ausente del universo visual del arte contemporáneo. 


\section{La Estructura del Holograma como Metáfora}

También las conjeturas sobre la similitud entre la estructura del universo y la del holograma son aprovechables para el arte desde el punto de vista conceptual. Las hipótesis arriesgadas por escritores, artistas y científicos de nuestros tiempos podrán parecernos tan ridículas como risibles parecieron a sus coetáneos las especulaciones de Julio Verne, Nicolás Coopérnico o Leonardo da Vinci, pero si bien en el campo científico se debe proceder con cautela a la hora de legitimar una teoría, en el terreno del arte, por el contrario, podemos jugar -afortunadamente- a ser más crédulos y hacer un uso libre de ella, sin temor a las inexactitudes científicas en que incurra, empleándola como metáfora del discurso artístico, como pretexto para reflexionar, ya que una obra de arte es, sobre todo, una ficción. Hay teorías que describen el universo como un holograma, recordemos que cada fragmento de una placa holográfica contiene la información de la imagen total, es decir que cada parte abarca el todo. En su libro La totalidad y el orden implicado, David Bohm manifiesta la falsedad de un mundo fragmentado (2008).

Así, en vez de decir: "un observador mira un objeto", podemos decir con más propiedad: "se está produciendo una observación dentro de un movimiento no dividido que incluye esas abstracciones que solemos llamar "el ser humano" y "el objeto que él está observando (p. 56)

Afirmaciones como esta, en las que se manifiesta una visión del universo análoga a la imagen holográfica -en cuanto a su condición indivisible- se emparentan con otras avanzadas investigaciones de la física cuántica y con sus planteamientos sobre la existencia de un mundo conectado cuyos elementos son partes de un todo, en el que la separación individual es una ficción. Algo que no difiere mucho de las enseñanzas del hermetismo contenidas en el Kybalión. Entre las teorías que esgrimen varios especialistas hay algunas que manifiestan que nuestra realidad posee solo dos dimensiones y que lo evidenciado como tercera dimensión es una ilusión que emerge de la interacción de estas dos con el tiempo. Ya sabemos por Einstein que el tiempo es un concepto relativo, algo que solo se cobra sentido en relación al sistema de referencia que tenga un observador. Científicos de la Universidad Tecnológica de Viena aseveran la posibilidad de que estemos viviendo dentro de un holograma. "Todo nuestro universo podría ser mucho más plano de 
lo que parece, por lo menos, matemáticamente hablando" (Forbes, 2015). He aquí una de las investigaciones cuya hipótesis pudiera funcionar como metáfora dentro de una exposición de arte holográfico. Las posibilidades son ilimitadas.

\section{Conclusiones}

Etérea y sublime, la imagen holográfica escapa al mercado, a los curadores, y al interés de un público cuyos ojos permanecen ciegos a la belleza de lo diferente. Ávidos de la confortable repetición de lo que ya conocen, los espectadores pasan por alto estas experiencias y los compradores adquieren aquellos productos que reconocen como obras de arte, hechos en aquellos lenguajes que han sido dignificados por el sistema promocional vigente, que lejos de contribuir a la investigación de los discursos artísticos más arriesgados conservan las garantías inofensivas de lo ya establecido.

La expansión de los conocimientos sobre las técnicas holográficas y sus posibilidades en el arte, la difusión mediante clases y talleres sobre los variados mecanismos que existen para hacer hologramas de mínimo costo -casi domésticos, imperfectos a veces pero igualmente válidos como medios de expresión- y la sinergia entre las instituciones artísticas y científicas, serían muy importantes para el desarrollo de la holografía. Sabemos que hay muchos artistas incorporando a sus creaciones estas técnicas pero -como siempre ocurre en el mundo del arte- la producción de la obra no es suficiente. No basta con los objetos que produzcan los artistas aislados en sus estudios, el arte es un sistema de relaciones donde participa la obra como un elemento más de una estructura compuesta por contextos, instituciones, críticos, comisarios, valores de mercado y público (entre otros componentes).

Sin un interés por priorizar el valor cultural de estas -ya no tan nuevasformas de representación, la holografía corre el riesgo de quedarse en manos de comerciantes que solo explotan su faceta espectacular o que promueven como hologramas proyecciones 3D sobre pantalla líquida, aumentando la desinformación y banalizando los verdaderos valores que este recurso posee. Afortunadamente existen instituciones que trabajan por el desarrollo de esta modalidad artística -ya podemos llamarle así-, como es el caso de Dados Negros, Centro de Holografía y Artes en España, Le musee de l'holographie en Francia o el Holocenter, Center for the Holographic Arts en Estados Unidos. Iniciativas como estas abren una ventana esperanzadora.

Cada vez más precisa y potente, ganando en consistencia y color, la imagen 
holográfica seabre camino en todos los espacios de laviday porsupuesto, también en el arte, aunque con una lentitud sorprendente si consideramos el tiempo transcurridodesdelaprimeramuestradehologramas, comoprecisaDadosNegros:

La primera exposición de holografía tuvo lugar en Michigan en 1968 y la segunda en Nueva York en 1970. En 1971 se fundó una Escuela de Holografía en San Francisco, la primera en la que científicos, ingenieros y artistas podían aprender la nueva técnica. De este modo la holografía se convirtió en un ejemplo inusual de campo científico en el que participaron en su desarrollo grupos de personas de muy distinta procedencia, desde físicos e ingenieros hasta artistas (s.f.).

Tanto tiempo después resulta asombroso que este tipo de imagen, sorprendente y fantasmagórica, no se haya integrado al arte con más frecuencia e intensidad, tal como lo han hecho la fotografía, las técnicas digitales u otros avances tecnológicos.

\section{Referencias}

Abramson, N.H. (2000). Incoherent holography. Recuperado de http:// proceedings.spiedigitallibrary.org/proceeding.aspx?articleid $=921387$

Augier, A. G. (2013) Holograbados, una tecnología creada en Cuba. Revista Anales de la Academia de Ciencias de Cuba. Recuperado de http:// www.revistaccuba.cu/index.php/acc/article/view/146

Beaty, W.J. (1995). Abrasion Holography, hand-draw holograms.

Recuperado de http://amasci.com/amateur/holo1.html_

Benton, S., Greguss, P., Huhtamo, E., Kac, E. \& Koski J. (1999). Kangastus -Mirage, Holografia-taiteen näyttely ..Helsinski: Rauman taidemuseo.

Bohm, D. (2008). La totalidad y el orden implicado (6ta ed.). Barcelona: Kairós

Caufield, H. (Ed.). (2016). The Arte and Science of Holography: A Tribute to Emmett Leith and Yuri Denisyuk. Orlando: SPIE Press.

Chiappiani, R. (2006). Christo and Jeanne-Claude: revealing an object by 
concealing it. Milán: Skira

Cottington. D. (2002). Cubismo: Movimientos en el Arte Moderno (Serie Tate Gallery). Madrid: Ediciones Encuentro.

Dados Negros. Centro de holografía y artes (s.f.). Introducción a la

holografia. Recuperado de http://www.dadosnegros.com/centro-de-

holografia-y-artes/introduccion-holografia/

Dalí, S. (1972) The 3rd Dimension: The 1st World Exposition of Holograms Conceived by Dali. New York: M. Knoedler and Co.

Dueñas, J. (2001). Silencio y vacio. Recuperado de http://www.

realidadesinexistentes.com/silencio-y-vacio

Fer, B., Batchelor, D. \& Wood, P. (1999). Realismo, Racionalismo y

Surrealismo. El arte de las entreguerras (1914-1945) Madrid: Ediciones Akal.

Fernández, J.A. (2004). Tres dimensiones en la historia de la fotografía. La imagen estereoscópica. Málaga: Miramar.

Forbes, F. (2015, 13 de Mayo). ¿Vivimos en un holograma? Es más probable de lo que puedas pensar. Recuperado de https://www.institutodraco. com/es/article/23/-vivimos-en-un-holograma-es-mas-probable-de-loque-puedas-pensar

Gabor, D. (1948, Mayo 15). A new microscopic principle. Nature, 161, 777778

Haupt, G. \& Binder, P. (2001). Shu-Min Lin: entrevista Universes in Universe. Recuperado de http://universes-in-universe.de/car/venezia/ bien49/twn/s-lin-s-int.htm

Huo, N. (2010, 25 de Mayo). Flying colors: holographic art of Dieter Jung. Shenzhen Daily, p. 15

Johnston, S.F. (2006). Holographic visions. A History of New Science .

Oxford : Oxford University Press.

Menna F. (1977). La opción analítica en el arte moderno: figuras e iconos. Barcelona: Gustavo Gili.

Ozaki, M., Kato, J. \& Kawata,S. (2013, 20 de septiembre). Color selectivity of surface-plasmon holograms iluminated with white light Applied Optics, 52 (27), 6788-679

Pérez, J.L. (2015). ¿Qué es un holograma? (el arte holográfico).

Recuperado de http://www.lienzos.net/2011/07/que-es-un-hologramaarte-holografico.html

Sharp,W. (1970, Marzo). Nauman Interview . Arts Magazine , 44, 22-27 
Starick, P. (1995, 13 de septiembre). Holograms reflect our progress. The Advertiser, p. 8

Viera, H. \& Ferreira L. (2006). La Holografía. Recuperado de http://www.revistabiosofia.com/index.php?option=com content\&task=view\&id=115\&Itemid

Angel Alonso: Crítico de arte y artista plástico. Ediciones ARTE CUBANO Consejo Nacional de las Artes Plásticas.

Contact Address: 3ra \#1205 entre 12 y 14. Miramar. Playa. Habana, (Cuba).

E-mail address: angelalonso2010@gmail.com 


\section{$B R: A C \equiv$}

Instructions for authors, subscriptions and further details:

http://brac.hipatiapress.com

Dibujo Fisionómico del Rostro. Historia de una Deriva entre la Clasificación y la Ficción

Andrea Lucio Sotelo ${ }^{1}$

1) Universidad de Barcelona (España)

Date of publication: June $3^{\text {rd }}, 2016$

Edition period: June 2016 - October 2016

To cite this article: Lucio, A. (2016). Dibujo fisionómico del rostro. Historia de una deriva entre la clasificación y la ficción. Barcelona, Research, Art, Creation, 4(2), 187-204. doi: 10.17583/brac.2016.1676

To link this article: http://dx.doi.org/10.17583/brac.2016.1676

\section{PLEASE SCROLL DOWN FOR ARTICLE}

The terms and conditions of use, except where otherwise noted, are related to the Open Journal System and to Creative Commons Attribution License (CCBY). The indication must be expressly stated when necessary. 
BRAC - Barcelona Research Art Creation. Vol. 4 No. 2, June 2016, pp. 187-204

\section{Physiognomic Drawing of Face. History of a Derive between the Categorization and Fiction}

Andrea Lucio Sotelo

University of Barcelona (España)

(Received: 2 August 2015; Accepted: 2 April 2016; Published: 3 June 2016)

\section{Abstract}

The interpretation of the face and its inexhaustible meaning transformation gives a space of centrality in the Western hermeneutics. However, man has tried to build unity and ordering experience through theoretical spaces; this categorization desire of knowledge has been materialized in the physiognomy, half pagan, half illustrated. The taxonomization process that undertook many medieval knowledge unknow the

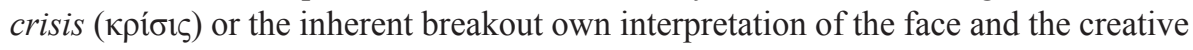
capacity. This obstacle however remains very present in the physiognomic drawing as the impossibility of their scientific aspirations while binds to the fiction

Keywords: Physiognomy; drawing; face; fiction; alterity 
BRAC - Barcelona Research Art Creation. Vol. 4 No. 2, June 2016, pp. 187-204

\section{Dibujo Fisionómico del Rostro. Historia de una Deriva entre la Clasificación y la Ficción}

Andrea Lucio Sotelo

Universidad de Barcelona (España)

(Recibido: 2 Agosto 2015; Aceptado: 2 Abril 2016; Publicado: 3 Junio 2016)

\section{Resumen}

La interpretación del rostro y de su inagotable transformación de significado le da un espacio de centralidad en la hermenéutica occidental, al tiempo que le hace escurridizo. Sin embargo, el hombre ha tratado de construir unidad y ordenar la experiencia a través de espacios teóricos; este anhelo clasificatorio del conocimiento se materializó en la fisonomía, mitad pagana, mitad ilustrada. El proceso de taxonomización que acometieron muchos conocimientos medievales desconocen la crisis (крíбı) o la ruptura inherente a la propia interpretación del rostro y a la capacidad creadora. Este escollo que sin embargo continua muy presente en el dibujo fisionómico marca como imposibles sus aspiraciones científicas al tiempo que le liga a lo ficcionado.

Palabras clave: Fisionomía, dibujo, rostro, ficción, alteridad 
pesar de la siempre diversa interpretación del rostro y de su inagotable posibilidad de transformación en el significado histórico y personal, el hombre ha tratado de construir unidad y orden en ese conjunto de elementos diversos que es el rostro: expresión física, natural, del pensamiento, de la experiencia o de la imaginación. El motivo de tal intento clasificatorio del conocimiento se materializó en la fisionomía, mitad pagana, mitad ilustrada; como ha dicho bien Juan Bordes: "la fisionomía es un ejercicio intuitivo que todos practicamos, pues juzgar lo oculto por sus signos externos es una actitud común. [...] Y consecuencia de esta intuición individual todas las culturas han confeccionado teorías fisiognómicas más o menos explicitas" (Bordes, 2012, p.290). La gestación de estas teorías han acompañado los inicios del aprendizaje del dibujo en las cartillas o tratados y a pesar de su relación estrecha con el dibujo, la fisionomía ha desconocido la actitud titubeante y expresiva de la actividad creadora; rechazo que esta muy relacionado a la determinación por convertirse en ciencia e ignorar la potencia poética y narrativa de la contradicción que es inherente a la fisionomía debido a un cierto deseo imposible y alquímico de la interpretación de lo externo para concluir la forma y características de lo interno.

La primera premisa de la ciencia de la fisionomía se basa en la idea de que se pueden hallar elementos universales y rasgos generales en la particularidad del rostro. La segunda premisa reside en considerar que esos rasgos comunes físicos están vinculados a ciertas disposiciones del individuo, es decir, que existiría una correlación de sentido entre la forma exterior e interior del hombre.

En el fondo, el papel del dibujo de la fisionomía consistía en seleccionar las particularidades del rostro e interpretarlas según la propia práctica del dibujo, bien por analogía o bien por deducción directa, como indicios del carácter, la psicología o procedimientos que a través de la secuencia y/o la geometría intentan determinar el límite de la naturaleza animal de la humana; o la naturaleza noble de la malvada, etc. La dificultad de seleccionar o aplicar categorías a la representación desde una perspectiva objetiva fue, sin duda, uno de los motivos que alejaría la fisionomía de sus aspiraciones científicas; sin embargo, esta misma marca de arbitrariedad en la segmentación y análisis subjetivo de las partes del rostro lo acerca al espacio creativo. La relación contradictoria del dibujo fisionómico entre creación y ciencia, lleva a artistas 
como Goethe a expresar su escepticismo y por otro lado "a reconocer el virtuosismo de su amigo [Lavater] como observador, y por ello el interés de sus apreciaciones" (Plasencia, 1988, p.40). El dibujo de la fisionomía ha pretendido unir durante su historia una estructura natural de inestabilidad sin dar importancia a los escollos y la reflexión que deviene de tal rotura o crisis

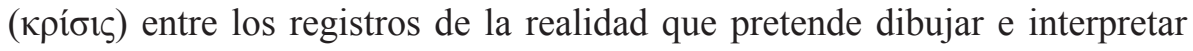
cuando se acerca al rostro. Sin embargo el punto de inflexión o крíбıৎ es fundamental en la creación: los múltiples puntos de elección que se dan durante la línea del desarrollo productivo de una obra, suelen ser los vértices necesarios que diferencian una línea recta productiva de una serpenteante línea de desarrollo creativo. Este componente dubitativo viene a evidenciar el marcado ser subjetivo de la interpretación del rostro por cuanto nuestra experiencia y por tanto los análisis derivados relacionados a este no puede sobrepasar el nudo hermenéutico sagrado que ha devenido en torno a él en la cultura occidental como veremos ha sucedido en la historia de la fisionomía.

\section{II}

Lo que los griegos llamaron fisionomía ( $\varphi v \sigma \iota \gamma v \omega \mu о v \imath \kappa \alpha ́)$ se practicaba mucho antes por los babilonios como uno de los métodos de adivinación dentro de la tradición griega, el tratado más antiguo sobreviviente sobre fisionomía data del siglo III a.C. y representa la primera recopilación sistemática de normas fisionómicas en occidente. De igual modo que que la teoría humoral y el temperamento, la fisionomía fue originalmente desarrollada por un grupo de médicos-filósofos utilizando un enfoque empírico basado en la analogía y la observación.

Aunque el origen de la fisionomía se remonta a la tradición hipocrática y a Aristóteles, fue en el Renacimiento cuando esta disciplina vivió su momento de mayor esplendor. Los estudios del renacimiento sobre fisionomía se basaban en cuatro textos paganos, en particular la Physiognominica, que entonces pasaba por obra de Aristóteles ${ }^{1}$. Aunque quizás, el surgimiento de la fisionomía como disciplina, tal como la conocemos, esta marcada por el espíritu cartesiano que entre el siglo XVII y siglo XVIII da cuenta de una nueva exégesis: las ciencias de la vida.

La estructura, al limitar y filtrar lo visible, le permite transcribirse al lenguaje. Gracias a ella, la visibilidad del animal o de la planta pasa entera al discurso que la recoge. Y, quizás llegado al límite, pueda 
restituirse a sí misma a la mirada a través de las palabras, como en los caligramas botánicos que soñaba Linneo. (Foucault, 1984, p.136)

El nuevo rumbo del conocimiento de lo vivo, de la historia natural y con ella la fisionomía, entendería que la posibilidad de acercarnos al saber dependía de estructuras concretas del conocimiento, ordenes taxonómicas que remitían, describían y agrupaban según la conveniencia de la estructura ideada; el rostro como estructura pasaría a dividirse y traducir sus rasgos a expresiones críticas. La retícula del nuevo conocimiento cartesiano segmentaría el dominio del reino vegetal y del animal de tal forma que cada ser recibiría un nombre y enunciaría desde éste a la familia perteneciente: "La historia natural habrá cumplido con su tarea fundamental que es 'la disposición y la denominación"” (Foucault, 1984, p.142).

Desde esta perspectiva de catalogación, la historia de la fisonomía dividió en dos ramas principales los conocimientos que ancestralmente se habían relacionado a la fisionomía: una astrológica y otra naturalista. La rama astrológica se basa en el principio de melothesis ${ }^{2}$ o tradición que asignaba partes del cuerpo para cada uno de los signos del zodiaco, en ella la cabeza correspondía a Aries y las partes del cuerpo restantes se asignaban a los otros once signos zodiacales ${ }^{3}$; estos estudios consideraban al hombre como un microcosmos, al que afectan diferentes estados de ánimo y de actuación relacionados al cosmos.

Según Caro Baroja la rama naturalista de la fisonomía fue clasificada en tres grupos por Giovanni Battista Della Porta (Vico Equense 1535 - Nápoles 1615), para poder ser estudiada. Ésta taxonomía se dividía en: fisonomía zoológica, fisonomía etnológica y fisonomía humoral; todas poseen un nivel relacionado a la patognómica ${ }^{4}$ y a pesar de que han tenido estrechas relaciones entre sí pueden ser diferenciadas.

Por un lado, la tendencia de la fisonomía zoológica, elige en los animales ciertas predisposiciones que luego, por analogía, son comparadas a aquellos hombres que comparten sus rasgos físicos. Esta interpretación fisonómica se reactiva durante el Renacimiento gracias a Della Porta, eslabón esencial en la historia de la disciplina.

La fisonomía etnográfica, que ponía en correspondencia las características físicas de ciertas razas con determinados caracteres, y la fisonomía psicológica, que correlacionaba determinadas características anatómicas con ciertos temperamentos o humores. 
En 1586 en la primera edición de la De Humana libri physiognomia de Della Porta, se ofrecía un resumen de los conocimientos fisonómicos adquiridos hasta entonces como una codificación bastante completa de los rasgos físicos del rostro y sus supuestas características psicológicas, junto con una serie de láminas en las que se comparaba el rostro de un hombre y la cara de un animal.

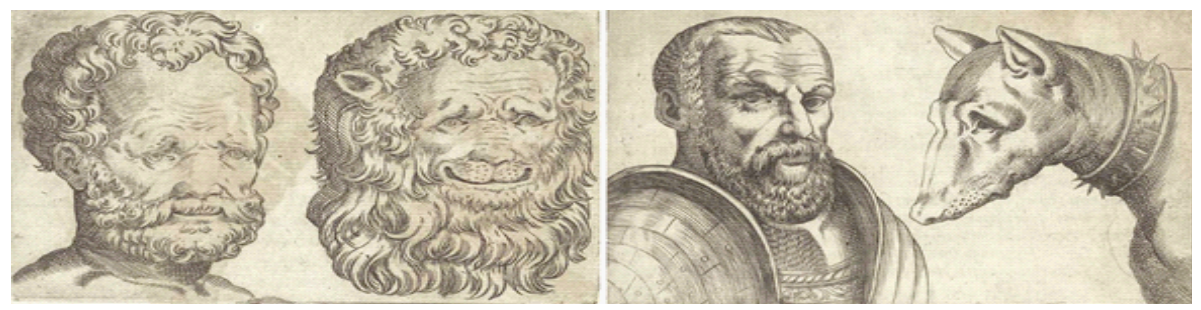

Figura 1. Giambattista Della Porta, De humana physiognomonia libri IIII, Napolés 1586.

La obra de Della Porta constituyó durante años el punto de referencia fundamental de su momento y del futuro, por cuanto sería "un precedente de lo que un par de siglos después constituirá una de las teorías más revolucionarias del mundo moderno: el evolucionismo de Charles Darwin" (Plasencia, 1988, p.37). Hasta que en 1667 el pintor Charles Le Brun publicó en París: Conférences sur l'expression des differents caracteres des passions. Le Brun aporta dos elementos fundamentales: por una parte, introduce el estudio de las pasiones, es decir, de los estados pasajeros del alma y su dinamismo, y por otra, lo hace desde una perspectiva pictórica, es decir, indica cómo se han de representar esas pasiones. Le Brun como muchos pintores de su época estaban influidos por una rama artísticofilosófica proveniente de la tradición estética y por otra medicocientífica del nuevo método cartesiano. Desde este punto de vista es posible entender que por un lado afirmara que la síntesis trágica del artista es obtenida con el recurso poético de la expresión, concepto esencial del pensamiento estético clásico del retrato. Y por otro lado, su trabajo teórico se fundamentara en la lectura del Les Passions de l'âme de René Descartes, a partir del cual entiende que la transcripción gráfica y expresiva de la esencia de las pasiones del alma se hace posible gracias a un estudio racional de las mismas.

De igual modo que Della Porta, también Le Brun presenta todo un 
bestiario, especialmente en su Traité de a Physionomie ou sur les rapports de la Physionomie de l'homme avec celle des animaux. Es por ello que en sus obras, las imágenes de hombres se yuxtaponen a dibujos de animales de frente y perfil resaltando sus parecidos. Podríamos decir que su minuciosidad y exactitud confieren a esas imágenes algo pavoroso, animal, más propio del reino mágico de las fábulas y de la Edad Media que del racionalismo del siglo de las luces.

En cierto modo la complejidad de los estudios de Le Brun, respecto a ciertos tratados clásicos anatómicos, incorporaba nuevamente el carácter psíquico del cuerpo y renovó el interés por la fisionomía animalista en los círculos artísticos durante los siglos XVII y XIX. Le Brun adopta las pautas de conveniencias y la retórica del gran siglo; pero la catalogación de los patrones expresivos basados en Caractères des passions de Marin Cureau de la Chambre (SaintJean d'Assé 1535 - 1615), lo cual le ayuda a elaborar valores universales que pretenden depurar la forma de las pasiones mediante la transcripción gráfica del mecanismo pasional, intentando esquivar el obstáculo del empirismo y de la copia servil. El proyecto de Le Brun supone además de una práctica pictórica y fisiológica; la exploración de las condiciones que unen lo bello y lo verdadero, ingente tarea que permanecerá como misterio.

Tal como en periodos anteriores a finales del siglo XVIII y principios del XIX, la fisionomía vive un nuevo renacer, podríamos decir que muy posiblemente por el deseo de reconciliar la ciencia y la religión. Un pastor protestante suizo de firmes creencias religiosas como Johan Kaspar Lavater (Zürich 1741-1801) seguramente no debió ignorar estos esfuerzos, que se quedaría reflejada en su obra de 1772: Physiognomische Fragmente. Esta obra de carácter enciclopédico, en la que colaboró el joven Goethe, aportaba a la fisionomía tanto una sistematización como integración de los conocimientos procedentes de las nuevas disciplinas, a la vez que muchos sentimientos religiosos se traducirían paulatinamente a tendencias 'científicas' del mundo natural. "La obra de Lavater se compone, en realidad, de una serie de disertaciones superpuestas, en las que las declamaciones y las apreciaciones sobre obras de arte van por un lado y las viejas teorías fisiognómicas por otro" (Caro Baroja, 1988, p. 212).

Lavater fue un defensor de la observación - sobre todo visual ${ }^{5}$ - tal como era tendencia en la episteme de la Ilustración y se propuso ordenar mediante un sistema geométrico los rasgos de la cara (Lavater, 1894, p.97). Esta tarea le llevó a distinguir la fisionomía propiamente dicha, de la patognómica.

$\mathrm{Su}$ empresa, al igual que la de los anteriores fisónomos fue criticada con el 
paso de los años, no solo desde la ciencia sino también desde las humanidades. Quizás debido a que el intento por ajustar marcadas características faciales a una tipología psíquica a través del dibujo se acentuó con el tiempo como un mecanismo no mucho más que cómico.
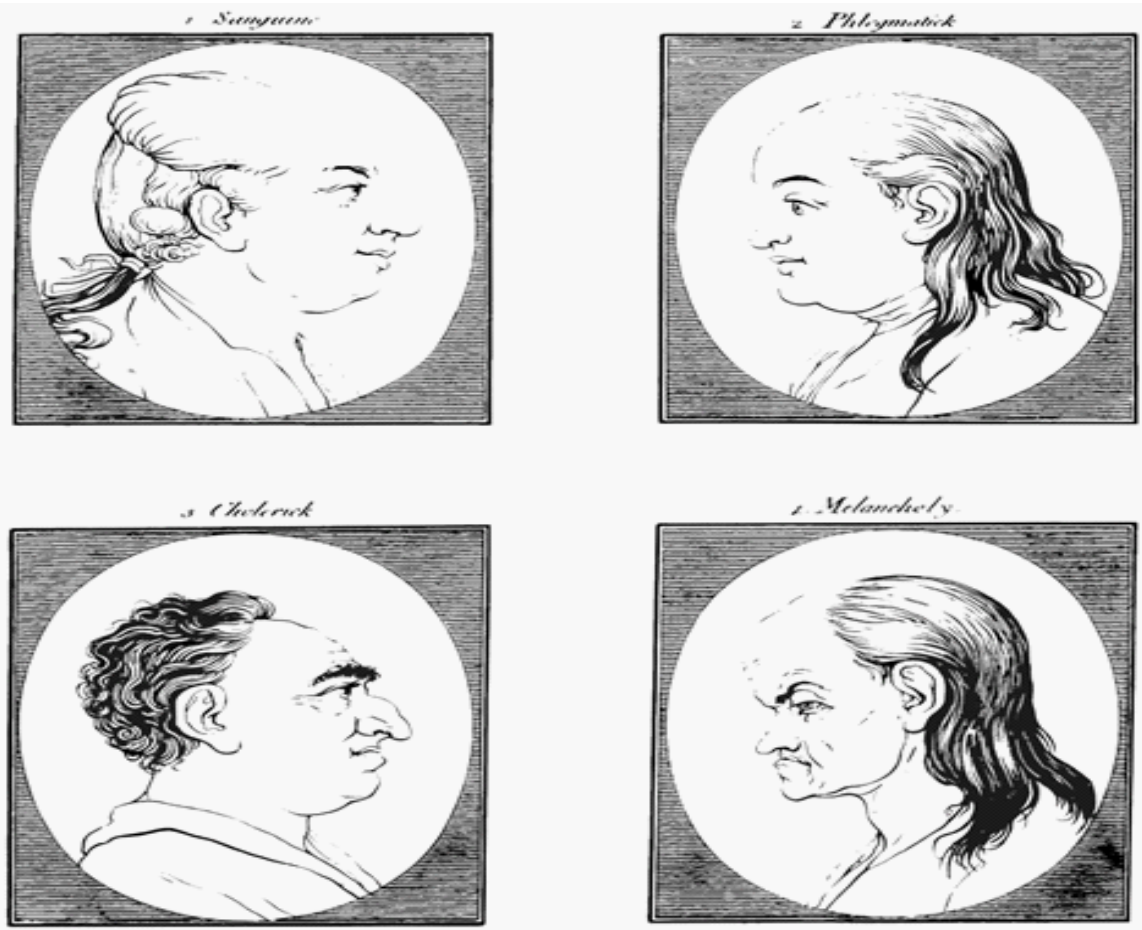

Figura 2. Lavater, Johann Caspar. Essays on physiognomy, designed to promote the knowledge and the love of mankind. Vol. 1. London: Printed for John Murray; H. Hunter; and T. Holloway, 1789-98. Original at Eighteenth Century Collections Online.

\section{III}

Me permito subrayar como a pesar del aumento de la influencia científica en nuestra época, muchas de las antiguas imágenes de fisionomía producen un cierto rechazo estético, el claro ataque de Luis Fernández a cierta perspectiva médica y de diseccionado que se encuentra representada en las 
obras de Lavater, según él, da cuenta de ello. Para Luis Fernández los dibujos sumadas a su discurso, podrían llamarse dibujos de 'decapitación': “A la luz de la modernidad, el proyecto de Lavater se revela, pues, no sólo como una empresa de colonización del cuerpo-exploración, delimitación, reparto-, sino como todas las taxonomías ilustradas con aspiraciones más o menos científicas" (Fernández, 2004, p.1-31), exhibe un carácter positivo que olvida la imposibilidad de definir un cuerpo como organismo separado de la psique ${ }^{6}$.

Esta reacción que evidencia el rechazo es la manifestación del choque entre el dibujo y el avance de la ciencia hacia múltiples esferas, el dibujo diseccionado no puede hablar mucho más lejos que de tanatopraxia y tanatoestética. Podríamos decir que la yuxtaposición de las imágenes de la historia de la fisionomía nos descubre una construcción del rostro contradictoria, escurridiza, a mayor información y clasificación de sus partes, mayor es la apariencia de un rostro muerto, la apariencia está recubierta por el dualismo vital del ordencaos y su equilibrio es crucial en los estudios artísticos, como no suele ser en la ciencia. Lo que Lavater espera de las señales del rostro ${ }^{7}$, mejor aún, lo que sabe que encontrará allí (Caro Baroja, 1988, p. 211-213) es menos una definición de una personalidad que un signo clasificatorio para el observador, es decir, para la mirada y sus riesgos.

El pintor Henry Fuseli y el filántropo Thomas Holloway participaron activamente en la obra de su amigo Lavater sobre el estudio de la persona basado en atributos físicos y sus obras reflejan por aquel entonces el interés por la expresión del rostro y el carácter lúdico del reconocimiento facial. El ejercicio de Lavater, que pretende otorgar leyes sobre tipologías de rostro nos acaba demostrando no solamente un componente psicológico referido a los prejuicios temporales, sociales y culturales; sino que también insinúa el juego de la diferencia y la similitud, sin duda es en ese interés humano de la imitación donde hunde sus raíces el que trabajos fisionómicos como del suyo nos sigan causando interés. Curiosamente a pesar de compartir época, los trabajos de un pintor como Fuseli distan mucho del análisis del dibujo realizado por Lavater, como muestra de las diferencias ideológicas que marcan a cada sujeto. Quizás podamos decir que la obra de Fuseli por no estar tan relacionada al resultado de ciertos preceptos ideológicos goza de mucha más naturalidad que la de Lavater. En relación a la perspectiva de cada sujeto el propio Caro Baroja dice:

Desde el momento en que empiezan los estudios de retratos, se observa que el juicio general sobre el personaje célebre retratado influye en lo 
que se dice de él, más que la observación objetiva. Cicerón será un modelo de 'homogeneidad' y Franklin de 'equilibrio', pero pronto se ve también que estos juicios de Lavater están sujetos al lugar común que domina en determinados ámbitos, concretamente el protestante de su tierra (Caro Baroja, 1988, p. 211).

El interés que puede suscitar el estudio del carácter relacionado al aspecto físico sigue estando vigente, aunque abordar tales estudios más allá del arte ha terminado por asociar "otras supuestas ciencias que no lo son y este cuerpo de doctrina arbitrario e indigesto se acepta por unos como algo dogmático, mientras que otros lo rechazan y ridiculizan una y otra vez" (Baroja,1988, p.16). Quizás sea sensato decir que la fisionomía adquiere valor desde una perspectiva filosófica o 'ciencia de la observación' -que no reescribiremos aquí pues ha sido ya descrita magistralmente por otros ${ }^{8}$ - devela un interés profundo:

Cette discipline, fondée sur l'observation du corps et visant, par le déchiffrement de son apparence, à la connaissance de l'homme, de son caractère, de ses moeurs, de ses passions, de ses origines, de son passé el même de son future constitue un effort pour penser en termes unitaires la dualité humaine physique et morale; c'est une enterprise remarquable de description détaillée du corps (Borderie, 2002, p.18).

Nuestra mirada abandona una forma metafísica para adoptar cada vez más una forma categorial que dota de unicidad a nuestra experiencia.

Un ejemplo de tal aplicación es el hecho de que la fisonomía haya abandonado su vertiente del pensamiento de la 'naturaleza' del aspecto particular del rostro de una persona, para constituirse pseudo ciencia, ya que su complejidad hace que su valía como conocimiento categorial sea dudosa. La evidente confusión de su discurso se debe, en mi modesta opinión, a la dificultad de hilar el espíritu anterior y posterior racionalista. Ciertas partes de la propia concepción de la interpretación del rostro asumen un conocimiento tácito, mientras que otras están exageradamente conceptualizadas.

El saber clásico pervivió en la fisiognomía en la idea de que ésta, como el resto de secretos naturales, se rige por el principio de simpatía y antipatía. En el pensamiento clásico griego, la physis (Фvбıৎ o natura), debía ser entendida porque existía la creencia de que el conocimiento de las leyes de la 'naturaleza' nos beneficiaría a todos; el saber de la fisonomía astrológica testimoniaba la 
conexión cósmica, bajo ésta idea el cuerpo del universo tenía mucho que decir del cuerpo humano, pero no había allí necesariamente una traducción, existía también un espacio ininteligible, mágico que el hombre moderno decidió olvidar, reconvirtiendo muchas tradiciones, creencias y mitos en espacios racionalizados.

La vigencia de las tradición mágica se postergaría debido a la mezcla de supersticiones antiguas y modernas, tal como concluye Burckhardt de su análisis sobre La cultura del Renacimiento en Italia (1860). Tal permanencia se gestionaría de forma diferente entre clases: "en las clases cultas se hallaba muy desarrollada la creencia en la Astrología. Cosas populares eran la observación de agüeros y presagios, la fe en los conjuradores y su mundo" (Caro Baroja, 1988, p.133).

La fisionomía "trató de sistematizar la intuición popular de que 'la cara es el espejo del alma' a través de los complejos vericuetos de los secretos de la naturaleza tan apreciados por los aficionados a la magia natural [fue] generalmente admitida en España como parte de la oculta filosofía que no traspasaba los límites de la ortodoxia, y fue conocida gracias a divulgadores como Jerónimo Cortés" (Laplana, 1996, p.142) en el siglo XVII, del cual el título de su obra evidencia la relación de la fisionomía con la tradición clásica: Phisonomía natural, y varios efectos de naturaleza.

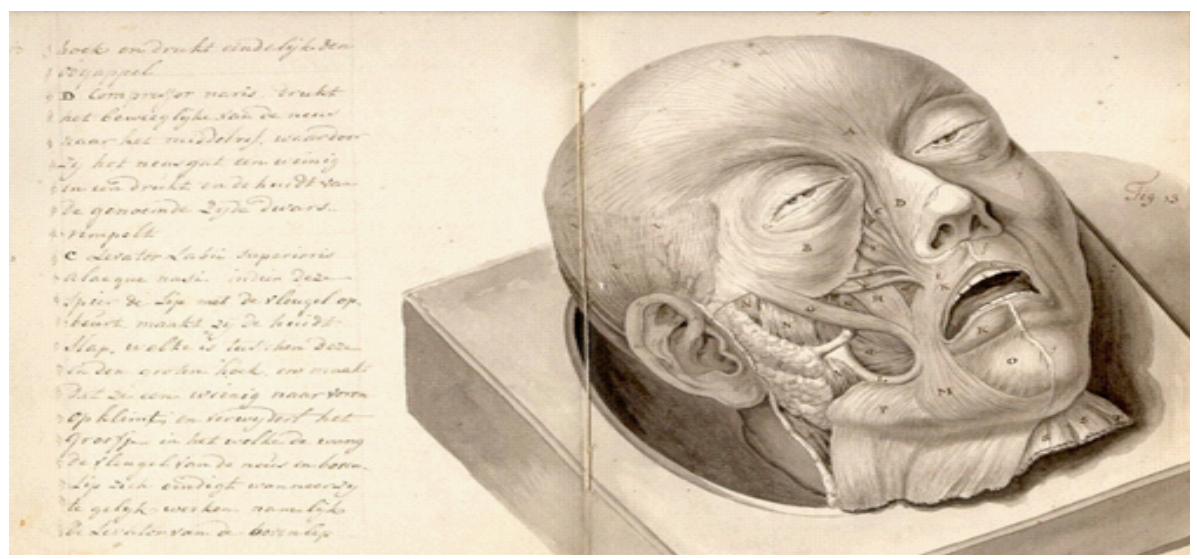

Figura 3. Anónimo, Treatise on physiognomy, Holanda 1790. 
Diríamos que la evidente relación con la tradición clásica se observa fuertemente en el corpus doctrinal ocultista de todas éstas obras que aunque en España no fuesen sobresalientes por dicha doctrina, tal como apunta Laplana, si lo fueron por el pensamiento mágico que en estas reverberaba

La fisiognomía podía convertirse en una ciencia determinista y adivinatoria al relacionarse con la astrología y la quiromancia, y por eso en el Index promulgado por Pablo IV en Roma en 1559 se incluía entre las artes prohibidas, como confirmó después la bula promulgada el 5 de enero de 1586 por Sixto V. En este sentido, es muy destacable el interés con que se acercaron a la fisiognomía algunos de los más importantes defensores del ocultismo, siempre en la difusa frontera entre la magia y la ciencia (Laplana, 1996, p.142).

Como puede suceder con la poética, el poder de significación del arte es precisamente el punto en que la palabra no llega, podríamos pensar que en la fisionomía, ese lugar, es el de su propia contradicción. Fue su intento por construir unidad lo que evidenció la división de su propia naturaleza ${ }^{9} \mathrm{y}$ quizás la que la hizo poco fiable y paulatinamente desaparecer.

De hecho la exigencia de la verdad, en la historia de la propia disciplina, ha tendido a erradicar los espacios especulativos y las posibilidades artísticas de la fisionomía. Sin embargo los acercamientos artísticos han pervivido a través de la 'fisionomía de los pueblos' o etnográfica en el siglo XIX, así como de la caricatura y el trabajo simbólico de la imagen de otros artistas del siglo XIX y XX.

Quizás una labor interesante en éste sentido sea la emprendida por el paleontólogo y divulgador escocés Dougal Dixon, que en un ejercicio de imaginación intenta explicar las leyes que rigen la evolución de los organismos para imaginarse al ser del futuro, el resultado: un libro ilustrado con el sugerente nombre de A Zoology of the Future (Dixon, 1981). Este libro de zoología ficción inspiró a artistas y zoólogos, Desmond Morris afirmó que le hubiera gustado escribirlo a él mismo, "hace muchos años, cuando era un joven zoólogo, empecé a inventar criaturas imaginarias, el dibujo y la pintura como un contraste agradable a las demandas de mis estudios científicos". Esa estética de lamina antigua que representa un ser mitológico hoy en día ha sido recuperada por trabajos como los de Neo Rauch. 
Es necesario que haya entre las cosas esta semejanza inmediata que permita a los elementos significantes el correr a lo largo de las representaciones, el deslizarse por su superficie, el asirse a sus similitudes para formar, por último, designaciones colectivas. Pero para esbozar este espacio retórico en el que los nombres toman poco a poco su valor general, no era necesario determinar el estatuto de esta semejanza, ni tampoco si en verdad estaba fundada; bastaba con que diera fuerza suficiente a la imaginación. Sin embargo, para la historia natural, lengua bien hecha, estas analogías de la imaginación no pueden tener el valor de garantías; era necesario que la historia natural, amenazaba bajo el mismo título que cualquier otro lenguaje, encontrara el miedo de rodear la duda radical que Hume planteaba con respecto a la necesidad de la repetición en la experiencia. En la naturaleza debe haber continuidad.

Esta exigencia de una naturaleza continua no tiene, desde luego, la misma forma en los sistemas y en los métodos (Foucault, 1984, p.146).

Las investigaciones y discusión que ha suscitado la interpretación de la expresión del rostro, revelan el interés de ciertas épocas por el ser humano como lugar de transmisión, como ser en tanto que otro existe. Es llamativo que en obras emblemáticas de la fisionomía como De Humana libri physiognomia (Della Porta, 1586), Methode pour prendre a dessiner les passions (Le Brun, 1702) y Physiognomische Fragmente (John Caspar Lavater, 1775-78); la alteridad aparece también como un animal, paralelismo que Juan Bordes recoge en el subcapítulo Fisionomía estética: paralelo animal, en el que menciona la importancia de la "Revolución Francesa, como momento de implosión del bestiario caricaturesco político en toda Europa" (Bordes, 2012, p.295). La literatura también se ha referido a la animalidad o alteridad del hombre para referirse a aquello que le era desconocido, muy común en la novela científica, hoy en día llamada 'ciencia ficción'.

Este aspecto profano del ser humano que conforme avanzó la ciencia hubo de esconderse en los rincones del conocimiento, fue representado con maestría -y con esa carga de misterio que se le había otorgado- por diferentes movimientos estéticos a lo largo de la historia, dependiendo de los límites estéticos asumibles y del discurso predominante al cual pretendía hacer evidente; desde la recuperación de los lugares comunes del romanticismo, pasando por las expresiones exageradas de lo grotesco, hasta las metáforas visuales del surrealismo o anti-humanidad de los personajes de la ciencia ficción, la expresión visual a través de la analogía y la metáfora ha explorado 
los límites de la representación de la construcción del ‘yo’y la alteridad.

La tarea del rostro representado ya no es únicamente el de constituir una serie de rasgos identificables de un individuo concreto, no es exclusivamente y únicamente el icono de la individuación [...] Es en la artificiosidad de la tradición, de la manipulación, por la cual Brunelleschi pudo descubrir la perspectiva, en la responsabilidad de no abandonar el estudio del rostro al devenir azaroso — ni a los caprichos artísticos de la idiocia de un yo profundo-, pues su singularidad y su repetición son ya devenir, por-venir (Tornero - Amorós, 2011, p.123).

El rostro es el espacio central de la expresión de alteridad y su importancia en los registros simbólicos e imaginarios es tal, que a pesar de su cercanía, su representación es y será siempre un misterio como lo ha demostrado la representación artística a lo largo de los tiempos. La representación del rostro animal hoy en día no significa como antaño un intento por reconocer la naturaleza humana, sino la evidente condición de su extrañeza y de su imposibilidad.

Efectivamente la fantasía o ficción ponen en entredicho los espacios mismos de representabilidad y esto adquiere un valor mayor cuando los motivos o preocupaciones, de la imagen ya no están vinculados a la reproducción. De hecho la fantasía construye una realidad que no es evidente pero que sin embargo se hace presente, dando lugar a espacios que sin ser parte del mundo material -a partir del descubrimiento del inconsciente- son cada vez más consistentes.

Hoy en día aunque la construcción del mundo recae mayoritariamente en el pensamiento humano, a tal punto, que la razón ha llegado a negar otras formas de conocimiento sensibles; la ficción sigue siendo un espacio que nos permite habitar el mundo en sus formas complejas: "Porque la fantasía es conexión de capas del subconsciente y de las más altas producciones de la consciencia" (Ballestero, 1985, p.124).

La pregunta por la forma en el arte no es pues baladí, hablamos de como se construye la inscripción de la representación y del reconocimiento de la imaginación para la pervivencia de éste conocimiento y por una fisionomía de la alteridad que entiende que el rostro es el espacio empírico del otro como expresión de un mundo posible ${ }^{10}$-espacio metafísico- . La fisionomía de la alteridad debería abandonar sus exigencias objetivas y convencerse de sus posibilidades imaginativas y narrativas. 


\section{BRAC - Barcelona Research Art Creation, 4(2)}

\section{Notas}

${ }^{1}$ Ésta decía: "El carácter mental no es independiente e inmune al proceso corporal, antes bien, está condicionado por el estado del cuerpo [...] Y a la inversa, es evidente que en el cuerpo influyen los efectos del alma." (ms. s. IV a.C.) 1497, Venetia.

${ }_{2}$ Melothesis era una parte muy útil del kit de herramientas del astrólogo con aplicaciones en el diagnóstico y tratamiento de la enfermedad.

${ }^{3}$ Fue hasta antes del s. I d.C que algún texto de astrología sobreviviente incorporó juicios sobre fisonomía y fue incorporada como una disciplina de la astrología, se atribuye como fundador de la medicina astrológica a Beroso, sacerdote que vivió en Babilonia en el siglo III aC.

${ }^{4}$ Lavater distinguió la fisiognómica como los "rasgos permanentes", en contraposición a la patognómica, ciencia que Lavater consideraba puramente subsidiaria porque se limitaba a los gestos transitorios de la cara y sólo aspiraba a descifrar en ellos la expresión puntual de esta o la otra pasión. (Lavater, 1775). Éste aspecto rechazado por algunos estudiosos renacentistas, es en la actualidad estudiado por la psicología positivista como microgestos, desarrollada fundamentalmente por Paul Ekman (Ekman, 1972).

5 'Le talent de l'observation parait la chose la plus facile, - et cependant rien n'est si rare [...] Observer, ou apercevoir les objets en les distinguant est l'âme de la physiognomie: c'est proprement en quoi elle consiste." (Lavater 1894, I, p.319)

${ }^{6}$ En términos anteriores al descubrimiento del inconsciente y la psique, los filósofos se cuestionaban por la relación organismo muerto/vivo. En La fenomenología del espíritu Hegel cuestiona la fisiognómica de Lavater aludiendo a si lo muerto puede gobernar o imponerse a lo vivo. ¿Puede, una cosa muerta como los huesos craneanos imponer su conformación a los movimientos del espíritu? ¿no existirá, más bien entre las dos partes, una especie de adaptación libre e imprevisible? (Hegel, 1966)

${ }^{7}$ Desde un punto de vista estrictamente científico, el error de la fisiognómica parece haber sido conceder a la singularidad de cada rostro (que sería como la de las huellas dactilares) un valor semántico, de representación ético-anímica, perfectamente calibrable.

${ }^{8}$ J.C.Baroja, Historia de la fisiognómica: el rostro y el carácter (1988); Baltrusaitis. Aberrations, Essai sur la légend des formes (1957); M. Dumont, Le succes mondain d'une fausee science: la physiognomonie de Johann Kaspar Lavater (1984); J.J. Courtine et Cl Haroche, Histoire du visage, Paris, 1988; Fl. Caroli Storia della fisiognomica. Arte e psicologia da Leonardo a Freud, Milano, 1995.

${ }^{9}$ ECette discipline [c'est] un effort pour penser en termes unitaires la dualité humaine physique et morale (Borderie, 2002, p.18)

10 "En cada sistema psíquico hay un hormigueo de posibilidades alrededor de la realidad; pero nuestros posibles son siempre los Otros [Autres]. El otro [autri] no 
puede estar separado de la eexpresividad que lo constituye [...] El Otro [Autruil] como expresión de un mundo posible" (Deleuze, 2002, p.387).

\section{Referencias}

Ballestero, M. (1985). El devenir y la apariencia. Barcelona: Anthropos Editorial.

Borderie, R. (2002). Balzac, peintre de corps. La Comédie humaine ou le sens du détail. Paris: SEDES (Collection du bicentenaire / Groupe international de recherches balzaciennes).

Bordes, J. (2012). Historia de las teorías de la figura humana. Madrid: Ediciones Cátedra

Burckhardt, J.(2004). La cultura del Renacimiento en Italia. Edaf: Madrid. Caro Baroja, J. (1988). Historia de la fisiognómica: el rostro y el carácter. Barcelona: Ediciones Akal.

Caro Baroja, J. (1990). La cara, espejo del alma. Círculo de lectores: Madrid.

Della Porta, G. (1586). De Humana libri physiognomia. Vici Aequensis

[Vico Equense] : Apud Iosephum Cacchium.

Deleuze, G. (2002) Diferencia y repetición. Buenos Aires: Amorrortu. Dixon, D. (1981). A Zoology of the Future. St. Martin's Press: New York.

Ekman, P. (1972). Universals and Cultural Differences in Facial Expressions of Emotions. In Cole, J. (Ed.), Nebraska Symposium on Motivation (pp. 207-282). Lincoln, NB: University of Nebraska Press.

Fernández, L. (2004). Ponencia: Señales en el cuerpo: avatares literarios de la fisiognómica. Almeria: La Fundación Alonso Quijano.

http://www.alonsoquijano.org/cursos2004/cursos\%202005/promocion_ lect ura/ponencia/ponencia\%20luis\%20fernandez.pdf (URL).

Foucault, M. (1984). Las Palabras y las cosas: una arqueología de las ciencias humanas. Barcelona: Siglo XXI Editores.

Foucault, M. (2008). La arqueología del saber. Buenos Aires: Siglo XXI Editores S.A.

Hegel, G. W. F., (1966). Fenomenología del espíritu, México: Fondo de cultura económica.

Laplana, J. E.(1996). Un tratado de fisiognomía de 1650 - Universidad de 
Zaragoza. Barcelona: Scriptura (Num. 11). http://www.raco.cat/index. php/Scriptura/article/view/94738/142656 (URL).

Lavater, J. C. (1775-78). Physionomische Fragmente. Leipzig und

Wintertuhur, Weidmanns Erben und Reich, und Heinrich Steiner und

Compagnie.

Lavater, J. C. (1894). Essays on Physiognomy, trad. Thomas Holcroft, London, B. Blake, 13,Bell Yard, Temple Bar.

Le Brun, C. (1806). Traité de la Physionomie ou sur les rapports de la

Physionomie de l'homme avec celle des animaux. París: Chalcographie du Musée Napoléon.

Le Brun, C. (1702). Methode pour apprendre a dessiner les passions.

Amsterdam: F. Platts.

Le Brun, C. (2008). Conferencias. Consejo General de la Arquitectura

Técnica de España.

Plasencia, Carlos (1988). El rostro humano. Observación expresiva de la representación facial. Valencia: Universidad Politecnica de Valencia. Tornero-Amorós (2011). Retornos de lo sagrado: Consideraciones sobre la moral en la representación artística del rostro. Arte y Políticas de Identidad Vol.5. Murcia, Facultad de Bellas Artes. http://revistas.um.es/ api/article/view/146251(URL).

\section{Obras}

Figura 1. (1586). Della Porta, G. De humana physiognomonia libri IIII. http://www.nlm.nih.gov/exhibition/historicalanatomies/porta_home. html

Figura 2. (1789-98) Lavater, Johann C., Essays on physiognomy, designed to promote the knowledge and the love of mankind. Illustrated by more than eight hundred engravings. Executed by, or under the inspection of, Thomas Holloway. Translated from the French by Henry Hunter. Vol. 1. London: Printed for John Murray; H. Hunter; and T. Holloway. Original at Eighteenth Century Collections Online. https://commons. wikimedia. org/wiki/File:LavaterHollowayFaces.png

Figura 3. (1790) Anónimo, Treatise on physiognomy, Holanda. 
204 Andrea Lucio - Dibujo fisionómico del rostro

Andrea Lucio Sotelo: Artista Visual y Doctoranda de la Universidad de Barcelona.

Contact Address: Facultat de Belles Arts. Departament de Pintura. Pau Gargallo, 4. 08028 Barcelona (España).

E-mail address: andreal_so@yahoo.es 
Instructions for authors, subscriptions and further details:

http://brac.hipatiapress.com

\section{Tecnología y Creación Musical}

Salvador Oriola Requena ${ }^{1}$

1) Facultad de Educación. Universidad de Barcelona (España)

Date of publication: June $3^{\text {rd }}, 2016$

Edition period: June 2016 - October 2016

To cite this article: Oriola Requena, S. (2016). Tecnología y Creación Musical. Lleida: Editorial Milenio. [Review of the book]. Barcelona, Research, Art, Creation, 4(2), 205-206. doi: 10.17583/brac.2016.1417

To link this article: http://dx.doi.org/10.17583/brac.2016.1417

\section{PLEASE SCROLL DOWN FOR ARTICLE}

The terms and conditions of use, except where otherwise noted, are related to the Open Journal System and to Creative Commons Attribution License (CCBY). The indication must be expressly stated when necessary. 
BRAC - Barcelona Research Art Creation. Vol. 4 No. 2, June 2016, pp. 205-206

(Received: 11 February 2015; Accepted: 20 March 2016; Published: 3 June 2016)

\section{Reviews (I)}

Aviñoa, X. (ed.), Brugarolas, O., Ferrer, E., Rossinyol, O., Tamarit, R. Gustems, J., Martínez, M. L., Carbonell, J., Berenguer, J. M., De la Torre, M. J., Calderón, D., Giné, E., Cascudo, T., Palacios, M., Calmell, C., Polo, M., Faccio, J. J. (2014). Tecnología y creación musical. Lleida: Editorial Milenio ISBN: 978-84-9743-655-7. Depósito Legal: L 1.551-2014

Desde la época de la revolución industrial se establece una íntima relación entre música y tecnología; todos conocemos la repercusión que han tenido y tienen descubrimientos como la música grabada, Internet o los dispositivos móviles en la difusión y acceso a cualquier tipo de música. En cambio, es mucho menos conocida la aportación que la tecnología ha tenido en un campo tan atractivo y fructífero como es la creatividad musical.

Con el amplio desarrollo tecnológico que se da a partir de la revolución industrial se abren nuevos planteamientos por lo que a la creación musical se refiere. Estos planteamientos, tal y como afirma el doctor Aviñoa (editor y coautor), se alejarán cada vez más de la excelencia como garantía de proximidad y se acercarán a lo novedoso como argumento.

El libro que presentamos consiste en un compendio de textos, escritos por especialistas pertenecientes a diferentes disciplinas, que pretenden analizar y dar a conocer la importancia que han tenido avances tecnológicos de distinta índole en los mecanismos de difusión, producción y creación musical durante los dos últimos siglos. 
Los diecisiete capítulos que componen el texto están organizados en torno a tres grandes apartados. Un primer apartado, de carácter más técnico, se dedica a exponer detalladamente la evolución mecánica y productiva, experimentada por diferentes tipologías de instrumentos como los instrumentos de cuerda percutida (piano, órgano, etc.) o los instrumentos escolares, entre otros, y de qué forma esta evolución ha repercutido tanto en el proceso de recepción como en el de creación musical.

El segundo apartado, de carácter más analítico, dedica sus capítulos a explicar la influencia de la tecnología en aspectos diversos como por ejemplo la utilización de la voz como instrumento musical, el proyecto "Sonidos en Causa" llevado a cabo por la orquesta del Caos, la evolución de estilo en los guitarristas de jazz, o la música grabada.

Finalmente, el texto concluye con un último apartado titulado "Música, tecnología y pensamiento", el cual acoge un conjunto de reflexiones sobre aspectos creativos en relación a la música digital, a la gestación de un estilo artístico como fue el Modernismo musical, a la educación musical y a la notación en la música contemporánea.

Este libro es una aportación relevante al escaso terreno bibliográfico en nuestra lengua referente al desarrollo conceptual que deriva de la relación entre la creatividad musical y la influencia de las modificaciones tecnológicas de la misma. Con los avances tecnológicos que se han producido en los dos últimos siglos y el acceso democratizado a todos ellos, vemos que el concepto de creación musical está inmerso en una metamorfosis constante, pasando de ser un acto intelectual reservado a unos pocos, a ser un proceso dinámico más accesible para todos, basado en la experiencia y en la práctica. Tal y como afirma Berenguer (coautor y director de la orquesta del Caos), deberíamos aspirar a considerar todo proceso creativo como un modelo de ejercicio de libertad, plenamente alcanzable por cualquier ciudadano. En definitiva, conseguir que la creación musical, gracias a la tecnología y a los cambios sociales, sirva como proceso para estimular el espíritu creador y la capacidad crítica y autocrítica de las sociedades.

Salvador Oriola Requena Profesor Asociado. Facultad de Educación, Universidad de Barcelona. 